\title{
ENCYCLOPEDIA OF SUSTAINABILITY SCIENCE AND TECHNOLOGY
}

\section{Batteries: Overview of Battery Cathodes}

\author{
Marca M. Doeff \\ Materials Sciences Division \\ Lawrence Berkeley National Laboratory \\ University of California \\ Berkeley, CA 94720
}

\section{Glossary}

Anode-(negative electrode). This electrode donates electrons during cell discharge.

Battery-a device consisting of one or many electrochemical cells connected together, in which chemical energy is converted into power. These can be further categorized as primary (non-rechargeable) or secondary (rechargeable) systems.

Capacity-The amount of charge that a battery contains, often expressed as mAh or Ah. This depends on the size of the battery and its chemistry. Rated capacity also depends on the current used.

Cathode-(positive electrode). This electrode accepts electrons during cell discharge.

Cell-one unit of a battery, commonly consisting of an anode, a cathode, an electrolyte, separator, and two current collectors

Energy Density or Specific Energy-energy per unit volume or weight of a material or a device, respectively, often expressed as $\mathrm{Wh} / \mathrm{L}$ or $\mathrm{Wh} / \mathrm{kg}$. Energy is a product of the cell voltage and capacity per unit volume or weight.

Theoretical: based on weight or volume of the electrode active materials only Practical: based on the entire weight or volume of the device including inert components. It may be only $1 / 4-1 / 2$ of the theoretical energy density. It may 
also refer only to the useable portion of the theoretical capacity of the anode or cathode material itself.

Intercalation compound (host material, insertion compound)- Originally, this referred specifically to layered structures that can undergo insertion of ions or molecules between the van der Waals gaps, but is now commonly used for any structure that undergoes topotactic insertion reactions. For Li-ion battery materials, it refers specifically to compounds that undergo reductive insertion of lithium ions, such as graphite (used as an anode) or $\mathrm{LiCoO}_{2}$ (used as a cathode).

Jahn-Teller effect-the geometric distortion of non-linear complexes of certain transition metal ions to remove degeneracy. For example, $\mathrm{Mn}(\mathrm{III})$ in octahedral coordination is expected to have an electronic configuration of $\mathrm{t}_{2 g}{ }^{3} \mathrm{e}_{\mathrm{g}}{ }^{1}$. Elongation along one axis of the octahedron, for example, decreases the symmetry and removes the degeneracy.

Power Density and Specific Power-power per unit volume or weight, respectively, often expressed as W/L or W/kg. Power is the product of the current and the operating voltage. This is a function both of the materials used and the cell design.

Ragone plot-A plot showing the relationship between energy density and power density for any particular battery chemistry. This relationship is a function both of battery design and chemistry for Li-ion batteries.

Solid Electrolyte Interface (SEI)-a very thin (nanometer scale) layer formed on a lithium or lithiated graphite anode, which forms upon reaction with certain kinds of electrolytic solutions. The SEI is a specific kind of reaction layer that is ionically conductive but electronically insulating. It passivates the electrode, 
preventing further reaction with the electrolytic solution, and allows reversible operation of the device.

Specific Capacity-The amount of charge per unit weight that a battery electrode material contains, often expressed as $\mathrm{mAh} / \mathrm{g}$. This is a fundamental characteristic of the material, and depends upon its redox chemistry and structure.

Topotactic-a transformation in a crystal lattice involving displacement or exchange of atoms, which maintains the basic structure.

\section{Definition of the subject and its importance}

In a discharging battery, the cathode is the positive electrode, at which electrochemical reduction takes place. As current flows, electrons from the circuit and cations from the electrolytic solution in the device move towards the cathode. Although these processes are reversed during cell charge in secondary batteries, the positive electrode in these systems is still commonly, if somewhat inaccurately, referred to as the cathode, and the negative as the anode. Because this terminology is widespread throughout the Li-ion battery literature, this usage will be adopted for this article.

Li-ion batteries are dual intercalation systems, in which both the cathode and

the anode have structures that allow reversible insertion and extraction of lithium cations. In principle, there are numerous materials that undergo reversible intercalation and can serve as electrode materials. Hence the chemistry of the Li-ion battery is not fixed, unlike the great majority of battery systems. The choice of cathode greatly affects the performance and cost of a Li-ion battery; for example, it is a major determinant of energy density, since it 
typically has a lower specific capacity than the most common anode material, graphite (372 mAh/g), to which it must be matched.

\section{Introduction}

The very high theoretical capacity of lithium (3829 mAh/g) provided a compelling rationale from the 1970's onward for development of rechargeable batteries employing the elemental metal as an anode. The realization that some transition metal compounds undergo reductive lithium intercalation reactions reversibly allowed use of these materials as cathodes in these devices, most notably, $\mathrm{TiS}_{2}$ [1]. Another intercalation compound, $\mathrm{LiCoO}_{2}$, was described shortly thereafter [2] but, because it was produced in the discharged state, was not considered to be of interest by battery companies at the time.

Due to difficulties with the rechargeability of lithium and related safety concerns, however, alternative anodes were sought. The graphite intercalation compound (GIC) $\mathrm{LiC}_{6}$ was considered an attractive candidate [3] but the high reactivity with commonly used electrolytic solutions containing organic solvents was recognized as a significant impediment to its use. The development of electrolytes that allowed the formation of a solid electrolyte interface (SEI) on surfaces of the carbon particles was a breakthrough that enabled commercialization of Li-ion batteries [4]. In 1990, Sony announced the first commercial batteries based on a dual Li ion intercalation system [5]. These devices are assembled in the discharged state, so that it is convenient to employ a prelithiated cathode such as $\mathrm{LiCoO}_{2}$ with the commonly used graphite anode. After charging, the batteries are ready to power devices. 
The practical realization of high energy density Li-ion batteries revolutionized the portable electronics industry, as evidenced by the widespread market penetration of mobile phones, laptop computers, digital music players, and other lightweight devices since the early 1990s. In 2009, worldwide sales of Li-ion batteries for these applications alone were US\$ 7 billion [6]. Furthermore, their performance characteristics (Figure 1) make them attractive for traction applications such as hybrid electric vehicles (HEVs), plug-in hybrid electric vehicles (PHEVs), and electric vehicles (EVs); a market predicted to be potentially ten times greater than that of consumer electronics. In fact, only Liion batteries can meet the requirements for PHEVs as set by the U.S. Advanced Battery Consortium (USABC), although they still fall slightly short of EV goals.

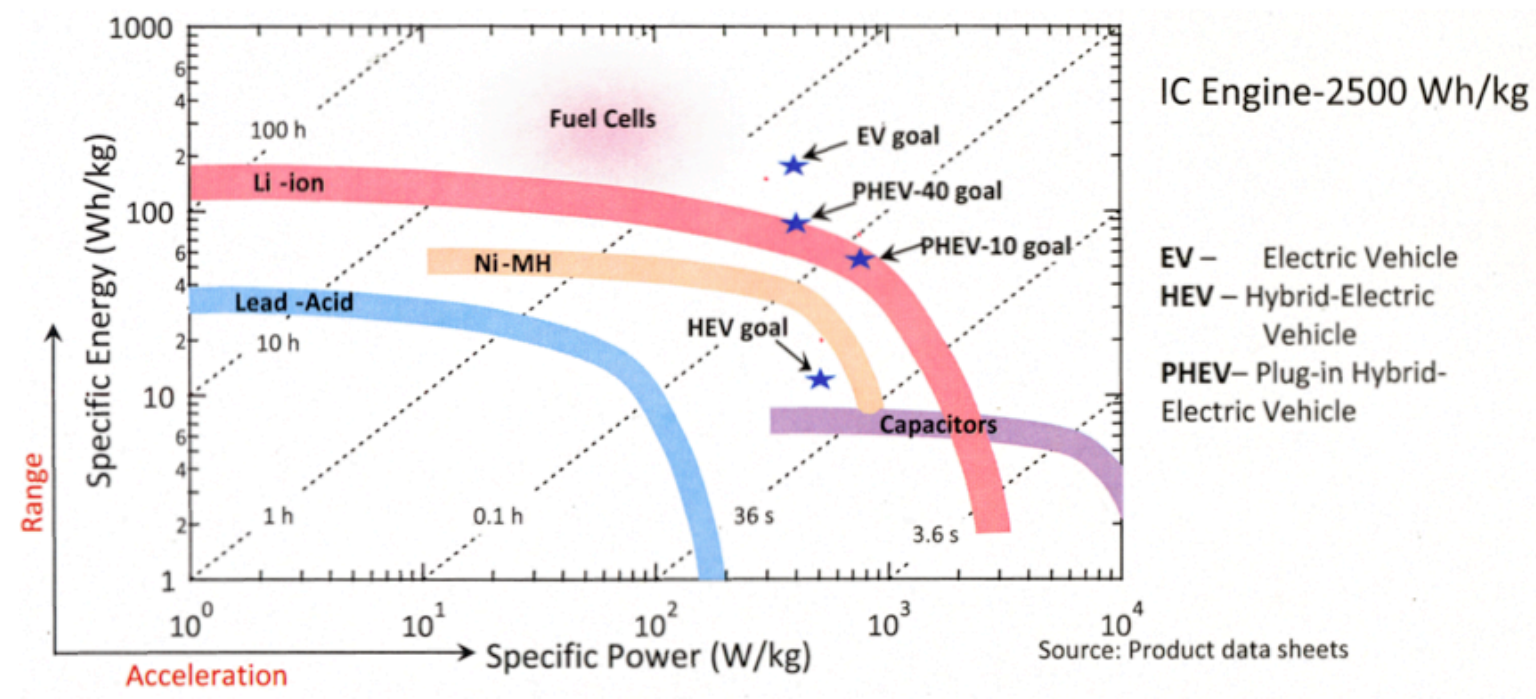

Figure 1. A Ragone plot, showing the relationship between specific power and specific energy for several types of electrochemical devices. Goals set by FreedomCar for HEV, PHEVs and EVs are also indicated. (Used with permission from Srinivasan, V. (2008) Batteries for Vehicular Applications. AIP Conference Proceedings Physics of Sustainable Energy 1044: 283. 
In the case of Li-ion batteries, the trade-off between power and energy shown in Figure 1 is a function both of device design and the electrode materials that are used. Thus, a high power battery (e.g., one intended for an HEV) will not necessarily contain the same electrode materials as one designed for high energy (i.e., for an EV). As is shown in Figure 1, power translates into acceleration, and energy into range, or miles traveled, for vehicular uses. Furthermore, performance, cost, and abuse-tolerance requirements for traction batteries [7] differ considerably from those for consumer electronics batteries. Vehicular applications are particularly sensitive to cost; currently, Li-ion batteries are priced at about $\$ 1000 / \mathrm{kWh}$, whereas the USABC goal is $\$ 150 / \mathrm{kWh}$ [8]. The three most expensive components of a Li-ion battery, no matter what the configuration, are the cathode, the separator, and the electrolyte [9]. Reduction of cost has been one of the primary driving forces for the investigation of new cathode materials to replace expensive $\mathrm{LiCoO}_{2}$, particularly for vehicular applications. Another extremely important factor is safety under abuse conditions such as overcharge. This is particularly relevant for the large battery packs intended for vehicular uses, which are designed with multiple cells wired in series arrays. Premature failure of one cell in a string may cause others to go into overcharge during passage of current. These considerations have led to the development of several different types of cathode materials, as will be covered in the next section. Because there is not yet one ideal material that can meet requirements for all applications, research into cathodes for Li-ion batteries is, as of this writing, a very active field. 


\section{Characteristics of battery cathode materials}

Modern cathode materials for Li-ion batteries are generally prepared in the lithiated (discharged) state, so that they can be paired with delithiated anodes such as graphite. For ease of handling, it is desirable that the material be reasonably air-stable at room temperature. Furthermore, graphite anodes impose a penalty of approximately $0.1 \mathrm{~V}$ in average cell potential compared to $\mathrm{Li}$ metal. To compensate for this, and also to maximize energy density, cathodes intended for use in $\mathrm{Li}$ ion batteries have higher average potentials vs. $\mathrm{Li} / \mathrm{Li}^{+}$than earlier materials such as $\mathrm{TiS}_{2}$ and vanadates [10] developed for $\mathrm{Li}$ metal batteries. Furthermore, the requirement for high specific capacity generally restricts choices to compounds containing first row transition metals (usually $\mathrm{Mn}, \mathrm{Fe}, \mathrm{Co}$, and $\mathrm{Ni}$ ). Environmental and toxicity concerns have precluded development of most $\mathrm{V}$ or $\mathrm{Cr}$-containing materials, although electro-active compounds containing these metals exist. Today's technologically important cathodes fall into two broad categories: metal oxides and poly-anionic compounds.

Figure 2 shows representations of the crystal structures of the most commonly used cathode materials for Li-ion batteries, and Table 1 summarizes their general properties. Figure 3 shows typical discharge profiles of selected materials in Li half-cell configurations. 


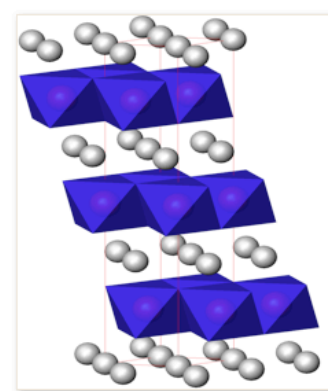

(a)

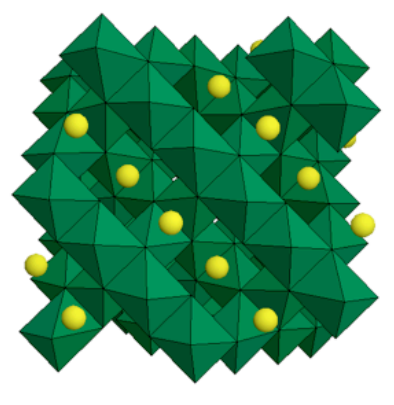

(b)

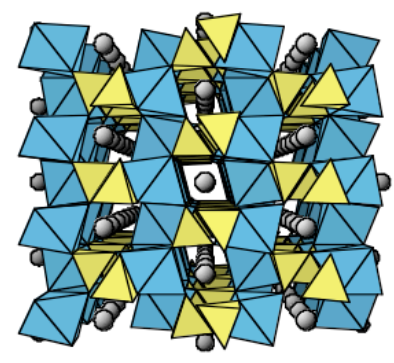

(c)

Figure 2. Structures of common cathode materials: a) the layered structure of $\mathrm{LiCoO}_{2}$, looking along the c-axis. The octahedrally coordinated $\mathrm{Li}$ ions in $3 a$ sites are represented as spheres and $\mathrm{CoO}_{6}$ (Co in $3 b$ sites) as octahedra, b) the cubic structure of $\mathrm{LiMn}_{2} \mathrm{O}_{4}$ spinel, with tetrahedrally coordinated $\mathrm{Li}$ ions (in $8 a$ sites) represented as spheres, and $\mathrm{MnO}_{6}(\mathrm{Mn}$ in $16 d$ sites) as octahedra, and c) the olivine structure of $\mathrm{LiFePO}_{4}$, looking down the b-axis. Octahedrally coordinated $\mathrm{Li}$ ions are represented as spheres, and $\mathrm{FeO}_{6}$ and $\mathrm{PO}_{4}$ as octahedra and tetrahedra, respectively. 
Table 1. Characteristics of Commercial Li-ion Battery Cathode Materials

\begin{tabular}{|c|c|c|c|c|}
\hline Material & Structure & $\begin{array}{l}\text { Potential vs. } \\
\mathrm{Li} \mathrm{Li}^{+}, \text {average } \\
\mathrm{V}\end{array}$ & $\begin{array}{l}\text { Specific } \\
\text { Capacity, } \\
m A h / g\end{array}$ & $\begin{array}{l}\text { Specific } \\
\text { Energy, Wh/kg }\end{array}$ \\
\hline $\mathrm{LiCoO}_{2}$ & layered & 3.9 & 140 & 546 \\
\hline $\begin{array}{l}\mathrm{LiNi}_{0.8} \mathrm{Co}_{0.15} \mathrm{Al}_{0.05} \mathrm{O}_{2} \\
(\mathrm{NCA})\end{array}$ & layered & 3.8 & $180-200$ & $680-760$ \\
\hline $\begin{array}{l}\mathrm{LiNi}_{1 / 3} \mathrm{Co}_{1 / 3} \mathrm{Mn}_{1 / 3} \mathrm{O}_{2} \\
(\mathrm{NMC})\end{array}$ & layered & 3.8 & $160-170$ & $610-650$ \\
\hline $\begin{array}{l}\mathrm{LiMn}_{2} \mathrm{O}_{4} \text { and } \\
\text { variants (LMO) }\end{array}$ & spinel & 4.1 & $100-120$ & $410-492$ \\
\hline $\mathrm{LiFePO}_{4}(\mathrm{LFP})$ & olivine & 3.45 & $150-170$ & $518-587$ \\
\hline
\end{tabular}

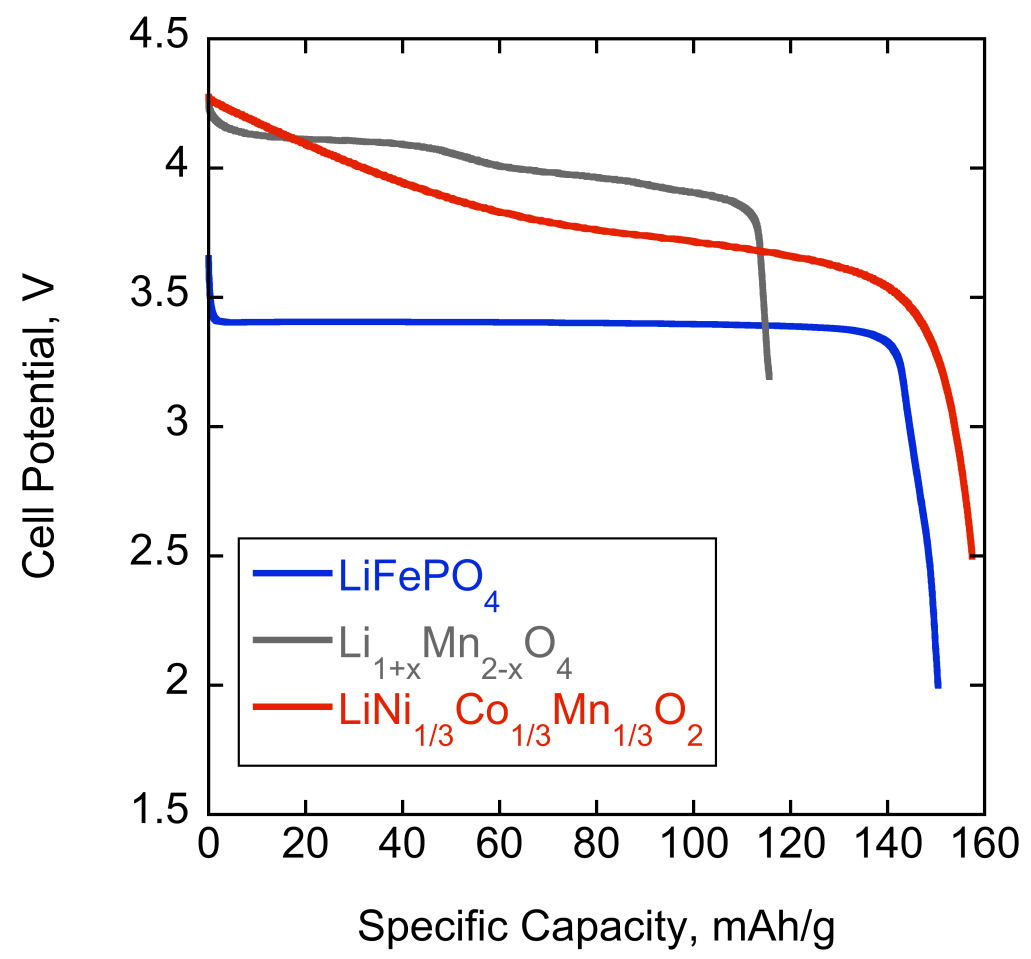

Figure 3. Discharge profiles of lithium cells containing $\mathrm{LiFePO}_{4}, \mathrm{Li}_{1+x} \mathrm{Mn}_{2-\mathrm{x}} \mathrm{O}_{4}$, or $\mathrm{LiNi}_{1 / 3} \mathrm{Co}_{1 / 3} \mathrm{Mn}_{1 / 3} \mathrm{O}_{2}$ electrodes. 


\section{Layered transition metal oxides}

$\mathrm{LiCoO}_{2}$ was the first of the layered transition metal oxides to be commercialized, and is still used today in batteries for consumer devices. It has the structure shown in Figure 2a, where Co and Li, located in octahedral sites, occupy alternating layers along the 111 planes in a cubic close-packed (ccp) oxygen array, to form a structure with overall hexagonal symmetry (space group $\mathrm{R}-3 \mathrm{~m})$. This type of stacking arrangement is called $\mathrm{O} 3$ in layer notation, indicating that there are three transition metal layers per unit cell and the $\mathrm{Li}$ ions are octahedrally coordinated.

Delithiation proceeds topotactically [11] and is reversible over the composition range $1 \geq x \geq \sim 0.5$ for $x$ in $\mathrm{Li}_{x} \mathrm{CoO}_{2}$, giving a practical specific capacity of about $140 \mathrm{mAh} / \mathrm{g}$ below $4.2 \mathrm{~V}$ vs $\mathrm{Li}^{2} \mathrm{Li}^{+}$. Extraction of lithium to values of $x<\sim 0.5$ results in higher practical capacities initially, but often increases cycling losses [12]. This has been attributed to side reactions involving particle surfaces, which increase cell impedance, and to structural instability associated with phase changes at very low values of $x$ in $\mathrm{Li}_{x} \mathrm{CoO}_{2}$ [13]. Coating $\mathrm{LiCoO}_{2}$ particles, or rigorous heat-treatment to remove surface species [14] results in improved cycling below $4.5 \mathrm{~V}$ vs $\mathrm{Li}^{\prime} \mathrm{Li}^{+}$, but full delithiation is still not possible without cycling losses.

A layered compound with the nominal composition of $\mathrm{LiNiO}_{2}$ has also been extensively studied for battery applications [15]. Its lower cost compared to $\mathrm{LiCoO}_{2}$, and the potential for higher energy density were driving forces for its development. Although the structure is similar to $\mathrm{LiCoO}_{2}, \mathrm{LiNiO}_{2}$ readily exhibits non-stoichiometry. During synthesis, there is a tendency towards loss of lithium and reduction of some $\mathrm{Ni}$ to the +2 oxidation state. The $\mathrm{Ni}^{2+}$ migrates to $\mathrm{Li}(3 a)$ sites, due to the similarities in size between the two types of ions. The actual 
composition can be written as $\mathrm{Li}_{1-z} \mathrm{Ni}_{1+z} \mathrm{O}_{2}$ with $0<z<0.2$, or as $\left(\mathrm{Li}_{1-}\right.$ $\left.{ }_{z} \mathrm{Ni}_{z}{ }^{2+}\right)_{3 a}\left(\mathrm{Ni}_{z}{ }^{2+} \mathrm{Ni}_{1-z}{ }^{3+}\right)_{3 b} \mathrm{O}_{2}$ [16]. The degree of disorder is influenced by the synthetic conditions, and the electrochemical properties (e.g., the first cycle reversibility) are affected by the degree of non-stoichiometry [17]. The difficulty in synthesizing high-quality $\mathrm{LiNiO}_{2}$ was one impediment to its widespread adoption as a cathode material in Li-ion batteries, although nearly ideal structures can be obtained if sufficient care is taken [16]. (However, perfectly stoichiometric $\mathrm{LiNiO}_{2}$ materials probably do not exist). Partial substitution of $\mathrm{Ni}$ with Co [18] was later found to be effective at reducing the cationic disorder on 3a sites, leading to compositions such as $\mathrm{LiNi}_{0.8} \mathrm{Co}_{0.2} \mathrm{O}_{2}$. Cobalt also helps to reduce oxygen loss at high states-of-charge, improving safety.

The thermal instability of $\mathrm{Li}_{x} \mathrm{NiO}_{2}$ at high states-of-charge [19] also raised a great deal of concern about the safety of this material when used as a cathode. The properties of $\mathrm{LiNiO}_{2}$ have been improved via coating and doping with $\mathrm{Mg}$, leading to a very high capacity electrode material [20] with better thermal properties. However, the most commonly used electrode material related to $\mathrm{LiNiO}_{2}$ is $\mathrm{LiNi}_{0.8} \mathrm{CO}_{0.15} \mathrm{Al}_{0.05} \mathrm{O}_{2}$ or $\mathrm{NCA}$, which is now commercially produced (see Table 1 for general properties). The presence of $\mathrm{Al}$ in NCA improves both the thermal [19] and electrochemical properties [21]. The high specific capacity, good power capability, and relatively low cost of this material make it attractive for vehicular applications although it is still not considered as inherently safe as other candidates such as LFP (see Table 2 and discussion of olivines below).

Several ternary Li-Fe-O phases exist with differing arrangements of cations in cubic close-packed oxygen arrays [22]. However, $\mathrm{LiFeO}_{2}$ with the R-3m structure is metastable and generally must be prepared via indirect methods such as ion exchange of $\mathrm{NaFeO}_{2}$. The electrochemical properties of this 
material [23] and most other polymorphs [24] are not, however, suitable for lithium ion batteries due to low and highly sloping voltage profiles or poor cycling properties. $\mathrm{Li}_{5} \mathrm{FeO}_{4}$ with the anti-fluorite structure has a potential profile that may be compatible in a Li-ion battery configuration, but delithiation does not appear to proceed via simple oxidative deintercalation [25]. This material has been proposed for use as a lithium ion source for lithium ion batteries (i.e., to lithiate graphite anodes so that cathodes in the charged state may be used).

Table 2. Relative Merits of Selected Commercial Li-ion Battery Cathode Materials for Vehicular Applications

\begin{tabular}{l|lllll}
\hline Cathode & Cost $^{\text {a }}$ & Energy Density & Specific Power & Safety $^{b}$ & Lifespan \\
\hline NCA & lowest & high & high & lowest & highest \\
NMC & medium & high & medium & medium & medium \\
LMO & medium & medium & medium & medium & lowest \\
LFP & medium & lowest & medium & highest & highest \\
\hline
\end{tabular}

a) Includes both raw material and processing costs. Processing costs may decrease over time, particularly for newer cathodes.

b) Intrinsic safety of material, apart from engineering controls in the battery itself.

Ternary Li-Mn-O phases with $\mathrm{Mn}$ in the +3 or +4 oxidation state crystallize as spinels, the rock salt structure $\mathrm{Li}_{2} \mathrm{MnO}_{3}$, or as orthorhombic $\mathrm{LiMnO}_{2}$ with a corrugated structure $\left(\mathrm{o}-\mathrm{LiMnO}_{2}\right)$ but not as $\mathrm{O} 3$ layered structures. Lithium manganese oxide spinels (LMO) are technologically important cathodes and will be considered in a later section (vide infra). The Na-Mn-O system contains 
numerous polymorphs, including layered structures. $\mathrm{NaMnO}_{2}$ has the same stacking arrangement as $\mathrm{LiCoO}_{2}$, but is monoclinically distorted (space group $\mathrm{C} 2 / \mathrm{m}$ ), due to the abundance of Jahn-Teller distorted $\mathrm{Mn}^{3+}$ ions. Ion exchange of this compound yields a layered $\mathrm{LiMnO}_{2}$ (designated O'3, with the prime indicating the monoclinic distortion) [26] but it rapidly converts to spinel upon electrochemical cycling, as does orthorhombic $\mathrm{LiMnO}_{2}$ [27]. O'3- $\mathrm{LiMnO}_{2}$, o$\mathrm{LiMnO}_{2}$, and spinel manganese oxide all have cubic close-packed oxygen arrays and differ only in the cation arrangement. Upon electrochemical delithiation of the first two materials, disproportion of $\mathrm{Mn}^{3+}$ into $\mathrm{Mn}^{2+}$ and $\mathrm{Mn}^{4+}$ ions occurs and $\mathrm{Mn}^{2+}$ ions subsequently migrate into vacant sites in the lithium layers via low energy pathways, facilitating structural rearrangement to spinel [28].

Lithium-deficient layered $\mathrm{Li}_{x} \mathrm{MnO}_{2+y}(\mathrm{x} \approx 0.7, \mathrm{y} \geq 0.05)$, which has an $\mathrm{O} 2$ rather than O3 stacking arrangement, does not convert to spinel upon cycling [29], because the oxygen array is not ccp. In addition, non-stoichiometric lithium manganese oxides that are intergrowths of $\mathrm{O} 2$ and $\mathrm{O} 3$ phases show better resistance to conversion than the pure O3 structure [30]. The presence of transition metal vacancies in these compounds (which reduce the concentration of the Jahn-Teller $\mathrm{Mn}^{3+}$ ions) results in low rate capability, because the vacancies tend to trap nearby lithium ions, impeding their mobility [31].

Other lithium manganese oxides with tunnel structures [32] exhibit interesting electrochemical properties, particularly those based on the $\mathrm{Na}_{0.44} \mathrm{MnO}_{2}$ structure. This material has excellent cycling characteristics [33] and rate capability [34], and does not convert to spinel, although the practical capacity is limited by voltage considerations (the average potential at which lithium is extracted is the highest of any known manganese oxide [35]). All of these tunnel 
and $\mathrm{O} 2$ or $\mathrm{O} 2 / \mathrm{O} 3$ layered materials, however, must be prepared via ion exchange of their sodium manganese oxide structural analogs, complicating their preparation. Furthermore, the lithium deficiency of the ion-exchanged materials limits capacity in Li-ion battery configurations, as all of the cycleable lithium must originate from the cathode.

$\mathrm{Li}_{2} \mathrm{MnO}_{3}$ can be considered a layered structure similar to $\mathrm{LiCoO}_{2}$, but with 111 planes alternately occupied by $\mathrm{Li}$ and $\mathrm{Li}_{1 / 3} \mathrm{Mn}_{2 / 3}$. Ordering of $\mathrm{Li}$ and $\mathrm{Mn}$ in the transition metal layer imposes a monoclinic superstructure, but the stacking arrangement is essentially identical to that of the $R-3 m$ structures discussed above. Mn in this compound is tetravalent and all lithium sites are occupied, precluding either oxidative de-intercalation or reductive intercalation. Nevertheless, several researchers have observed electrochemical activity of $\mathrm{Li}_{2} \mathrm{MnO}_{3}$ when it is charged in lithium half-cells to high potentials [36]. Recent evidence [37] suggests that lithium de-intercalation occurs with simultaneous oxygen loss during the initial charge, as well as $\mathrm{H}^{+} / \mathrm{Li}^{+}$exchange. The converted material becomes electroactive and can subsequently be lithiated during cell discharge. Acid leaching of $\mathrm{Li}_{2} \mathrm{MnO}_{3}$ also yields an electroactive manganese oxide phase [38]. The reaction involves loss of $\mathrm{Li}_{2} \mathrm{O}$ from the structure and ion exchange, to produce layered $\mathrm{H}_{1-\mathrm{x}} \mathrm{Li}_{\mathrm{x}}\left[\mathrm{Li}_{0.33} \mathrm{Mn}_{0.67}\right] \mathrm{O}_{2}$ [39].

The compound $\mathrm{Li}_{1.2} \mathrm{Mn}_{0.4} \mathrm{Cr}_{0.4} \mathrm{O}_{2}$ [40] is essentially a solid solution of layered $\mathrm{Li}_{2} \mathrm{MnO}_{3}$ and $\mathrm{LiCrO}_{2}$ with an $\mathrm{O} 3$ stacking arrangement [41]. Very high discharge capacities ( 200 mAh/g) can be obtained, based on $\mathrm{Cr}^{3+} \leftrightarrow \mathrm{Cr}^{6+}$ redox processes. Conversion to spinel phases does not occur because Mn remains in the +4 oxidation state throughout charge and discharge, nor does the electrode need chemical or electrochemical activation prior to use. Nevertheless, 
concerns over the environmental impact of hexavalent chromium have prevented further development of this material.

The search for improved layered oxide materials containing low cost transition metals ultimately led to the discovery of $\mathrm{LiNi}_{0.5} \mathrm{Mn}_{0.5} \mathrm{O}_{2}$ [42] as well as compounds with the general composition $\left.\mathrm{Li}\left[\mathrm{Ni}_{x} \mathrm{Li}_{(1 / 3-2 x / 3)}\right) \mathrm{Mn}_{(2 / 3-x / 3)}\right] \mathrm{O}_{2}$ [43]. Computational modeling [44] and spectroscopic investigations [45] show that the $\mathrm{Ni}$ and $\mathrm{Mn}$ in these materials are in the +2 and +4 oxidation states, respectively. During normal charge processes in an electrochemical cell, nickel is ultimately oxidized to the +4 oxidation state, and $\mathrm{Mn}$ remains tetravalent. $\mathrm{LiNi}_{0.5} \mathrm{Mn}_{0.5} \mathrm{O}_{2}$ does not convert to spinel upon cycling, unlike the metastable O3- $\mathrm{LiMnO}_{2}$, because no trivalent $\mathrm{Mn}$ is ever produced in the structure.

The defect chemistry of $\mathrm{LiNi}_{0.5} \mathrm{Mn}_{0.5} \mathrm{O}_{2}$ also distinguishes it from $\mathrm{LiNiO}_{2}$ (where nickel is primarily in the +3 oxidation state initially) discussed above. A feature of $\mathrm{LiNi}_{0.5} \mathrm{Mn}_{0.5} \mathrm{O}_{2}$ is anti-site mixing $[42,46]$ in which some $\mathrm{Ni}^{2+}$ ions are located on the $\mathrm{Li} 3 a$ sites, and some $\mathrm{Li}^{+}$ions on transition metal $3 b$ sites; i.e. $\left(\mathrm{Li}_{1-\mathrm{x}} \mathrm{Ni}_{\mathrm{x}}\right)_{3 \mathrm{a}}\left(\mathrm{Li}_{\mathrm{x}} \mathrm{Ni}_{0.5-\mathrm{x}} \mathrm{Mn}_{0.5+\mathrm{x}}\right)_{3 \mathrm{~b}} \mathrm{O}_{2} ; \mathrm{x} \approx 0.08-0.12 . \mathrm{Mn}$ ions in the transition metal layers preferentially surround the $\mathrm{Li}$ ions located in $3 \mathrm{a}$ sites to form $\mathrm{Li}_{2} \mathrm{MnO}_{3}$-like clusters, and Ni ions occupy sites adjacent to Mn, to form a "flower pattern" (Figure 4). The anti-site mixing is thought to be a thermodynamically favored feature of the ion ordering and thus intrinsic to the structure. Unlike with $\mathrm{LiNiO}_{2}$, simple manipulation of conditions during direct synthesis is therefore not likely to result in a near-ideal layered structure. 


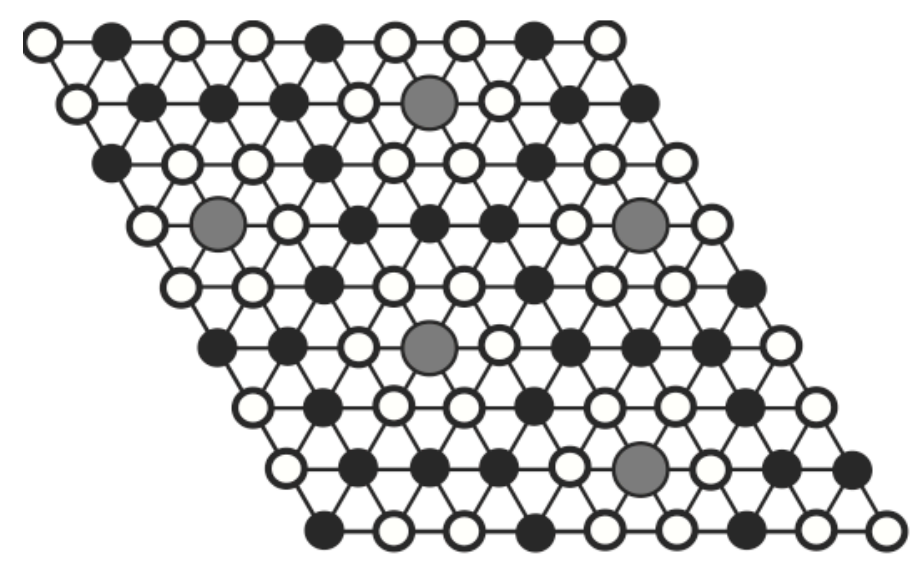

Figure 4. A transition metal layer in $\mathrm{LiNi}_{0.5} \mathrm{Mn}_{0.5} \mathrm{O}_{2}$ showing the flower pattern. $\mathrm{Li}$ is represented by the large gray circles, $\mathrm{Mn}$ by small white circles, and $\mathrm{Ni}$ by black circles. Used with permission from reference 46a.

$\left.\mathrm{Li}\left[\mathrm{Ni}_{\mathrm{x}} \mathrm{Li}_{(1 / 3-2 \times / 3}\right) \mathrm{Mn}_{(2 / 3-\times / 3)}\right] \mathrm{O}_{2}$ compounds can be considered solid solutions of $\mathrm{Li}_{2} \mathrm{MnO}_{3}$ and $\mathrm{LiNi}_{0.5} \mathrm{Mn}_{0.5} \mathrm{O}_{2}$. Although the discharge capacity between 4.4-3.0 V vs. $\mathrm{Li}^{\mathrm{Li}} \mathrm{Li}^{+}$drops as the $\mathrm{Ni}$ content decreases, the opposite trend is observed after cell charge to $4.8 \mathrm{~V}$ and subsequent discharge to $2.0 \mathrm{~V}$ [47]. In addition, the $\mathrm{Li}_{2} \mathrm{MnO}_{3}$-rich materials exhibit a plateau at about $4.5 \mathrm{~V}$ during charge, the length of which is inversely proportional to $\mathrm{x}$. This is thought to be de-intercalation of $\mathrm{Li}$ ions with concomitant loss of oxygen (for a net loss of $\mathrm{Li}_{2} \mathrm{O}$ ), similar to what happens when $\mathrm{Li}_{2} \mathrm{MnO}_{3}$ is charged in an electrochemical cell. This process can result in very high discharge capacities upon subsequent cycles (e.g., 230 $\mathrm{mAh} / \mathrm{g}$ for $x=1 / 3$ ). An advantage to these materials and related Li-rich materials (where excess lithium replaces some of the transition metal ions on $3 b$ sites, but the $\mathrm{Mn}$ content still equals that of the $\mathrm{Ni}$ content) is decreased cation mixing. This improves rate capability [48] compared to $\mathrm{LiNi}_{0.5} \mathrm{Mn}_{0.5} \mathrm{O}_{2}$.

The presence of a relatively large number of $\mathrm{Ni}$ ions in the $\mathrm{Li} 3 \mathrm{a}$ sites of the LiNi ${ }_{0.5} \mathrm{Mn}_{0.5} \mathrm{O}_{2}$ structure due to the anti-site mixing has a negative impact on the 
$\mathrm{Li}$ diffusivity, resulting in a low-rate cathode material. $\mathrm{LiNi}_{0.5} \mathrm{Mn}_{0.5} \mathrm{O}_{2}$, prepared by low temperature ion exchange of the nearly perfectly layered $\mathrm{NaNi}_{0.5} \mathrm{Mn}_{0.5} \mathrm{O}_{2}$, is capable of sustaining higher discharge currents than samples prepared by conventional methods [49]. However, the most successful method used to address this issue has been to incorporate some cobalt into the structure [50]. The best known of these compounds is $\mathrm{Li}\left[\mathrm{Ni}_{1 / 3} \mathrm{Co}_{1 / 3} \mathrm{Mn}_{1 / 3}\right] \mathrm{O}_{2}$, sometimes referred to as NMC (Tables 1 and 2). This compound is gradually replacing $\mathrm{LiCoO}_{2}$ in consumer batteries (in some cases, a mixture of the two are used as the cathode) and is under consideration for some vehicular applications. The voltage profile of NMC vs. $\mathrm{Li}^{\prime} \mathrm{Li}^{+}$is gradually sloping (Figure 3), as is typical of many layered compounds, and provides somewhat higher capacity than $\mathrm{LiCoO}_{2}$ below $4.3 \mathrm{~V}$ vs. $\mathrm{Li} / \mathrm{Li}^{+}$(typically about $160 \mathrm{mAh} / \mathrm{g}$ compared to 140). Capacities in excess of $200 \mathrm{mAh} / \mathrm{g}$ can be achieved when cells are charged to higher voltage limits, although this usually results in diminished cycle life.

The oxidation states of $\mathrm{Ni}, \mathrm{Co}$, and $\mathrm{Mn}$ in as-made $\mathrm{Li}\left[\mathrm{Ni}_{1 / 3} \mathrm{Co}_{1 / 3} \mathrm{Mn}_{1 / 3}\right] \mathrm{O}_{2}$ are $+2,+3$, and +4 , respectively [51]. First principle calculations suggest that $\mathrm{Ni}^{2+}$ is ultimately oxidized to $\mathrm{Ni}^{4+}$ during extraction of the first two-thirds of the lithium during electrochemical charging in lithium cells, and oxidation of $\mathrm{Co}^{3+}$ to $\mathrm{Co}^{4+}$ occurs only during removal of the last one-third [52] (i.e., at high cell potentials). As in $\mathrm{LiNi}_{0.5} \mathrm{Mn}_{0.5} \mathrm{O}_{2}, \mathrm{Mn}$ remains inactive throughout normal operating cell voltages. The redox activity of $\mathrm{Ni}$ during the extraction of lithium from $\mathrm{Li}\left[\mathrm{Ni}_{1 / 3} \mathrm{Co}_{1 / 3} \mathrm{Mn}_{1 / 3}\right] \mathrm{O}_{2}$ has been verified by in situ X-ray absorption spectroscopic (XAS) studies, although the details of the participation of Co in the electrochemistry are less clear [53]. Charge compensation associated with Co is currently thought to occur, at least partially, at oxygen sites, due to the covalency of the Co-O bonds. 
The improved electrochemical properties and better structural, chemical and thermal stability [54] of $\mathrm{Li}\left[\mathrm{Ni}_{1 / 3} \mathrm{Co}_{1 / 3} \mathrm{Mn}_{1 / 3}\right] \mathrm{O}_{2}$ compared to $\mathrm{LiCoO}_{2}$ or NCA render it an attractive replacement cathode material for consumer batteries. Nevertheless, the presence of a significant amount of costly cobalt, albeit in reduced quantities compared to $\mathrm{LiCoO}_{2}$, may still make it too expensive for most vehicular applications. Compounds having the general formula $\mathrm{Li}\left[\mathrm{Ni}_{x} \mathrm{Co}_{1}\right.$ $\left.{ }_{2 x} \mathrm{Mn}_{\mathrm{x}}\right] \mathrm{O}_{2}$ with $\mathrm{x}=0.4$ or 0.45 have recently been developed by Whittingham and co-workers specifically to address the cost issue [55]. Although the amount of anti-site mixing increases with larger $\mathrm{x}$, these materials exhibit very good electrochemical performances. The effect of increasing the Ni content of these materials on the thermal stability, especially at high states of charge, remains to be determined, however.

Another approach has been to partially substitute another metal such as aluminum for cobalt [56]. Although the amount of substitution must be kept low to maintain the high specific capacities, both the thermal stability of the delithiated materials [57] and the electrochemical properties [58] appear to be enhanced.

All of the NMCs discussed above contain equal amounts of $\mathrm{Ni}$ and $\mathrm{Mn}$, which ensure that the oxidation states of the two metals are primarily +2 and +4 , respectively. Recent attempts to increase $\mathrm{Mn}$ content in stoichiometric materials having the formula $\mathrm{Li}\left[\mathrm{Ni}_{0.45-\mathrm{x}} \mathrm{Co}_{0.1} \mathrm{Mn}_{0.45+\mathrm{x}}\right] \mathrm{O}_{2}$ yielded phase mixtures for values of $x>0.05$ [59] and a solid solution phase for $x=0.05$. In this compound, $\mathrm{Li}\left[\mathrm{Ni}_{0.4} \mathrm{Co}_{0.1} \mathrm{Mn}_{0.5}\right] \mathrm{O}_{2}$, the extra manganese is in the +3 oxidation state). Unfortunately, this material exhibits poorer capacity retention upon electrochemical cycling and lower rate capability than $\mathrm{Li}\left[\mathrm{Ni}_{0.45} \mathrm{Co}_{0.1} \mathrm{Mn}_{0.45}\right] \mathrm{O}_{2}$. It is, however, possible to form solid solutions between $\mathrm{Li}\left[\mathrm{Ni}_{1 / 3} \mathrm{Co}_{1 / 3} \mathrm{Mn}_{1 / 3}\right] \mathrm{O}_{2}$ and 
$\mathrm{Li}_{2} \mathrm{MnO}_{3}$ to make $\mathrm{Li}-$ and $\mathrm{Mn}$-rich materials where the excess $\mathrm{Mn}$ is in the +4 oxidation state. As with the related $\left.\mathrm{Li}\left[\mathrm{Ni}_{x} \mathrm{Li}_{(1 / 3-2 x / 3)}\right) \mathrm{Mn}_{(2 / 3-x / 3)}\right] \mathrm{O}_{2}$ compounds, these materials can be electrochemically activated during charge to high potentials in lithium cells. The activation process (deintercalation of $\mathrm{Li}$, concomitant loss of oxygen, and $\mathrm{H}^{+} / \mathrm{Li}^{+}$ion-exchange) yields electrodes with discharge capacities as high as $290 \mathrm{mAh} / \mathrm{g}$ [60]. The very high capacities make these materials interesting for both consumer and automotive applications, and they are now being actively developed (e.g., by Envia Systems, Hayward, CA).

\section{Manganese Oxide Spinels}

The marked tendency for many manganese oxide phases to convert to spinel structures during lithiation in electrochemical cells, or upon heating with a lithium source, attests to the stability of this structure in the Li-Mn-O system. The stoichiometric spinel, $\mathrm{LiMn}_{2} \mathrm{O}_{4}$, is easily synthesized in air from a variety of $\mathrm{Li}$ and Mn-containing precursors. Figure $2 \mathrm{~b}$ shows its cubic structure (space group $\mathrm{Fd}-3 \mathrm{~m}$ ), where $\mathrm{Li}$ ions occupy tetrahedral (8a) sites and $\mathrm{Mn}$ is located in octahedral $(16 \mathrm{~d})$ sites in a ccp array of oxygen anions. In addition, there are vacant tetrahedral and octahedral interstitial sites in the three-dimensional structure that provide pathways for lithium diffusion.

Early work [61] showed that it is possible to remove lithium from $\mathrm{LiMn}_{2} \mathrm{O}_{4}$ using a mild acid treatment. During this process, $\mathrm{Mn}$ is oxidized from an average +3.5 oxidation state to +4 , and $\lambda-\mathrm{MnO}_{2}$, which retains the spinel framework, is formed (equation 1). In addition, some dissolution of Mn occurs.

$$
2 \mathrm{LiMn}_{2} \mathrm{O}_{4}+4 \mathrm{H}^{+}(\mathrm{aq}) \rightarrow 2 \mathrm{Li}^{+}(\mathrm{aq})+\mathrm{Mn}^{2+}(\mathrm{aq})+2 \mathrm{H}_{2} \mathrm{O}+3 \lambda-\mathrm{MnO}_{2}
$$


Oxidative extraction of lithium from the tetrahedral $8 a$ sites of $\mathrm{LiMn}_{2} \mathrm{O}_{4}$ to form $\lambda-\mathrm{MnO}_{2}$ in a lithium cell [62] was subsequently demonstrated to occur slightly above $4 \mathrm{~V}$. It is also possible to insert lithium into the vacant octahedral sites of $\mathrm{LiMn}_{2} \mathrm{O}_{4}$ either chemically or electrochemically, with concomitant reduction of $\mathrm{Mn}$. When carried out in a cell with a lithium anode, this process occurs below $3 \mathrm{~V}$, and the discharge profile is flat, indicative of a two-phase reaction. The tetragonally distorted phase $\mathrm{Li}_{2} \mathrm{Mn}_{2} \mathrm{O}_{4}$ (space group $14_{1} / \mathrm{amd}$ ) is formed due to the cooperative Jahn-Teller effect, which occurs when more than half the manganese is in the form of $\mathrm{d}^{4}$ Jahn-Teller $\mathrm{Mn}^{3+}$ ions. The phase transition results in a $16 \%$ increase in the $c / a$ ratio [63] $(a=c=8.248 \AA$ in $\mathrm{LiMn}_{2} \mathrm{O}_{4} ; a=8.007 \AA, c=9.274 \AA$ in $\mathrm{Li}_{2} \mathrm{Mn}_{2} \mathrm{O}_{4}$ ). In theory, lithium cells containing $\mathrm{LiMn}_{2} \mathrm{O}_{4}$ can either be charged or discharged initially, and then cycled over a composition range of $0 \leq x \leq 2$ in $\mathrm{Li}_{x} \mathrm{Mn}_{2} \mathrm{O}_{4}$ to give a total specific capacity of 285 $\mathrm{mAh} / \mathrm{g}$. Figure 5 shows the voltage profile of a Li/modified $\mathrm{LiMn}_{2} \mathrm{O}_{4}$ cell assembled in the author's laboratory, after discharging into the $3 \mathrm{~V}$ region and full recharge. Both $4 \mathrm{~V}$ and $3 \mathrm{~V}$ plateaus are evident; although the overall capacity is somewhat lower than the theoretical value. 


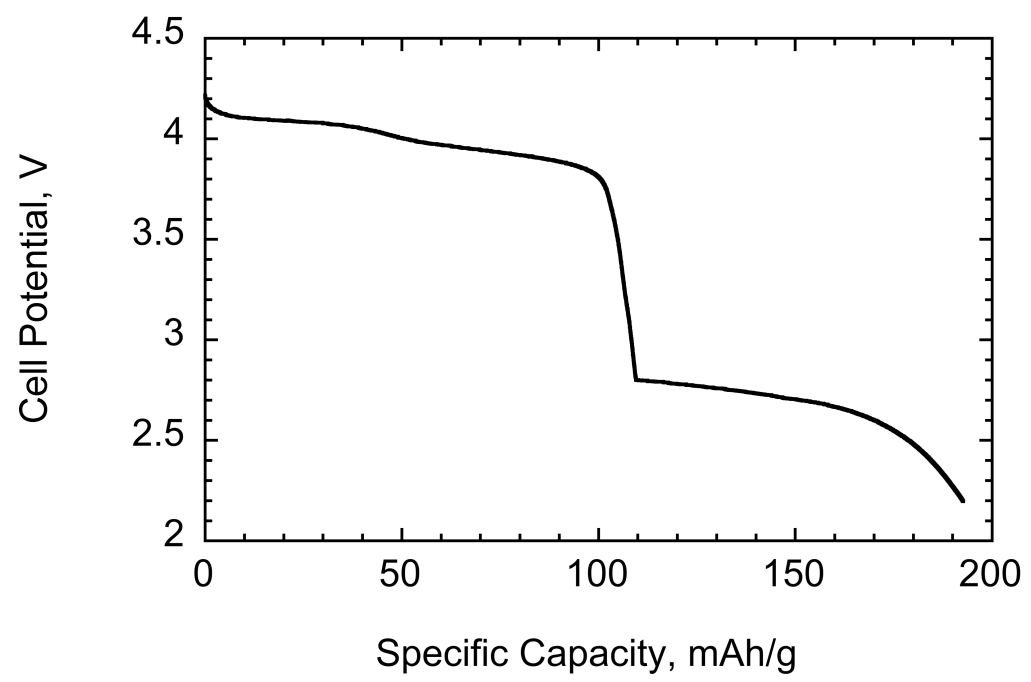

Figure 5. Discharge profile of a Li/modified-LiMn ${ }_{2} \mathrm{O}_{4}$ cell at $0.1 \mathrm{~mA} / \mathrm{cm}^{2}$. Cell was initially discharged to $2 \mathrm{~V}$ and then charged to $4.3 \mathrm{~V}$. This was the third discharge between 4.3-2.0V.

The large anisotropic volume change associated with formation of tetragonal $\mathrm{Li}_{2} \mathrm{Mn}_{2} \mathrm{O}_{4}$ results in particle disintegration and loss of connection within the composite electrode. This causes such a rapid loss of capacity, that, in practice, the cycle lives of cells containing $\mathrm{LiMn}_{2} \mathrm{O}_{4}$ discharged even a few times into the $3 \mathrm{~V}$ region are greatly compromised. In contrast, the extraction of lithium from $\mathrm{LiMn}_{2} \mathrm{O}_{4}$ above $4 \mathrm{~V}$ vs. $\mathrm{Li} / \mathrm{Li}^{+}$maintains the cubic structure and results in smaller volume changes. For this reason, discharge is typically limited to the $4 \mathrm{~V}$ plateau (Figure 3), which exhibits much better reversibility. The theoretical capacity associated with this plateau is $148 \mathrm{mAh} / \mathrm{g}$, although it is difficult to fully extract all the lithium, resulting in somewhat lower practical values.

From the early ' 90 s onwards, intensive efforts were devoted to the development of $\mathrm{LiMn}_{2} \mathrm{O}_{4}$ for lithium ion batteries, particularly at Bellcore Laboratories [64]. Although limiting discharges to the $4 \mathrm{~V}$ plateau resulted in much better cycling than when both the 3 and $4 \mathrm{~V}$ plateaus were utilized, 
gradual capacity fading was still observed [65]. This behavior was attributed to several factors, including irreversible side reactions with the electrolyte due to the high potential, loss of oxygen from the delithiated spinel, dissolution of $\mathrm{Mn}$, and production of tetragonal $\mathrm{Li}_{2} \mathrm{Mn}_{2} \mathrm{O}_{4}$ at particle surfaces, particularly at high discharge rates $[63,66]$.

Partial substitution of $\mathrm{Mn}$ to form $\mathrm{LiM}_{\mathrm{x}} \mathrm{Mn}_{2-\mathrm{x}} \mathrm{O}_{4}$, improves capacity retention [67]. Of particular interest are the lithium-substituted materials having the general formula $\mathrm{Li}_{1+x} \mathrm{Mn}_{2-x} \mathrm{O}_{4}$. As lithium is substituted for manganese on the $16 \mathrm{~d}$ sites ( $\mathrm{x}$ is increased), the average oxidation state of the latter rises. This effectively decreases the $4 \mathrm{~V}$ capacity in proportion to the amount of substitution but results in a higher average oxidation state of the $\mathrm{Mn}$ at the end-ofdischarge. This ameliorates the tendency to form the tetragonally distorted phase under non-equilibrium conditions such as rapid discharging, because this occurs only when the Mn oxidation state falls below an average of 3.5. Because Mn is fully oxidized before all the lithium can be extracted from $8 a$ sites, side reactions are suppressed. Finally, dissolution of Mn decreases because this phenomenon is dependent on the concentration of trivalent ions.

$\mathrm{Li}$ substitution and the attendant increase in $\mathrm{Mn}$ oxidation state in the asmade $\mathrm{Li}_{1+x} \mathrm{Mn}_{2-\mathrm{x}} \mathrm{O}_{4}$ compounds decrease the lattice parameter, a (Figures 6a and $b$ ). The magnitude of this value correlates closely with the amount of capacity loss upon cycling (Figure $6 c$ ), so that it can be used to predict the cycling behavior of the spinel materials [68]. In particular, improvements are most marked when $a \leq 8.23 \AA$. Because the cycling behavior is so much better than $\mathrm{LiMn}_{2} \mathrm{O}_{4}$, nearly all commercial manganese oxide spinel materials (LMOs) made today are lithium-substituted. These have theoretical specific capacities of 100-120 mAh/g (Table 1), somewhat lower than that for $\mathrm{LiMn}_{2} \mathrm{O}_{4}$. 

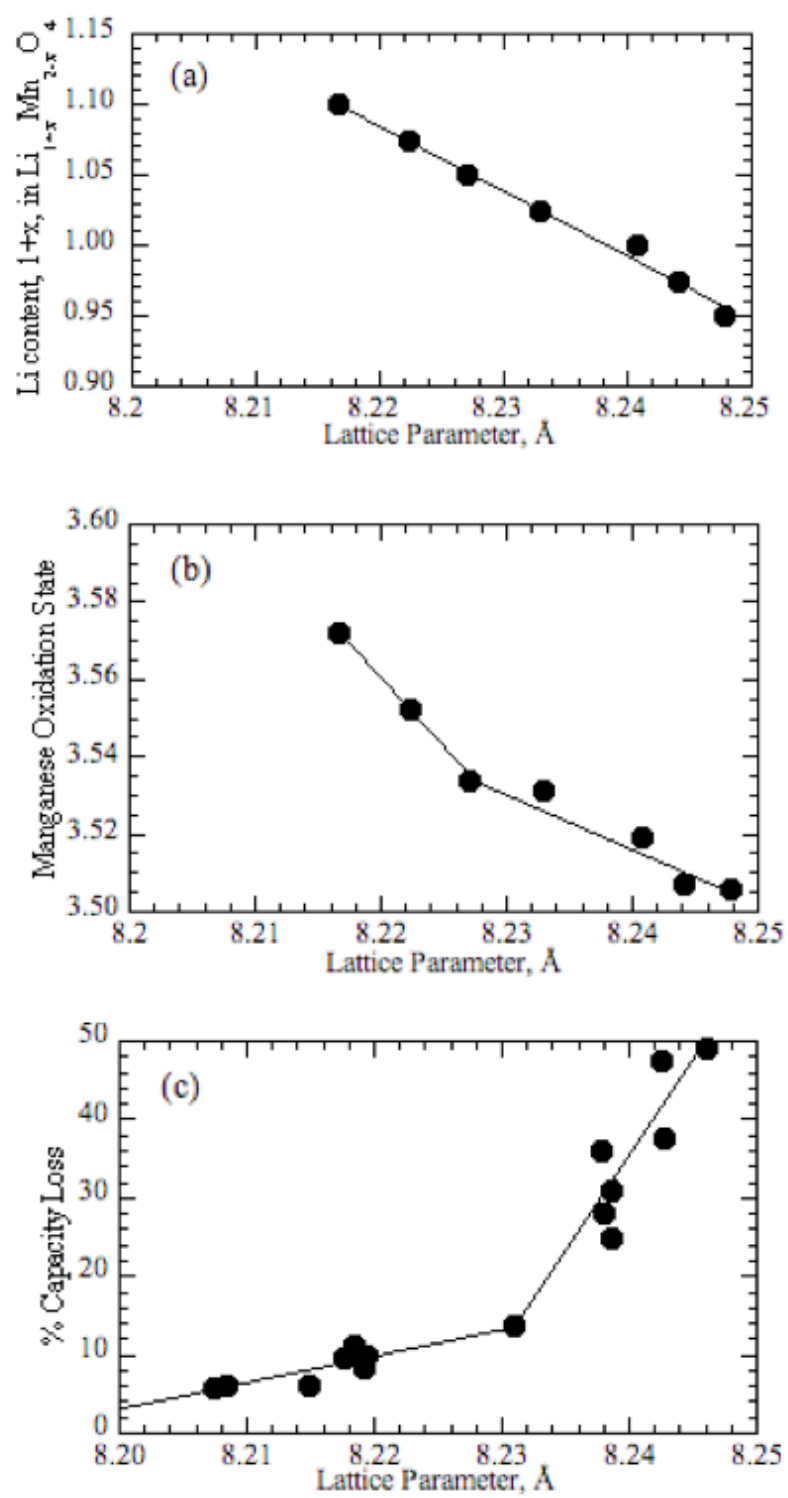

Figure 6. a) The variation of the lattice parameter, $a$, with the lithium content of $\left.\mathrm{Li}_{1+x} \mathrm{Mn}_{2-\mathrm{x}} \mathrm{O}_{4}, \mathrm{~b}\right)$ the variation of lattice parameter with the average $\mathrm{Mn}$ oxidation state in $\mathrm{Li}_{1+x} \mathrm{Mn}_{2-\mathrm{x}} \mathrm{O}_{4}$, and c) relationship between capacity loss after 120 cycles and the lattice parameter in $\mathrm{Li}_{1+x} \mathrm{Mn}_{2-\mathrm{x}} \mathrm{O}_{4}$. Used with permission from reference 68.

The maximum possible substitution in $\mathrm{Li}_{1+x} \mathrm{Mn}_{2-\mathrm{x}} \mathrm{O}_{4}$ corresponds to $\mathrm{x}=1 / 3$ (the compound $\mathrm{Li}_{4 / 3} \mathrm{Mn}_{5 / 3} \mathrm{O}_{4}$ or $\mathrm{Li}_{4} \mathrm{Mn}_{5} \mathrm{O}_{12}$ ), at which point all of the $\mathrm{Mn}$ is in the +4 oxidation state and there is no $4 \mathrm{~V}$ capacity, because oxidative extraction of 
lithium cannot occur. Nevertheless, it is possible to insert lithium reversibly into octahedral $16 \mathrm{c}$ sites at about $2.9 \mathrm{~V}$ vs $\mathrm{Li}^{\prime} / \mathrm{Li}^{+}$until a composition of $\mathrm{Li}_{7} \mathrm{Mn}_{5} \mathrm{O}_{12}$ is reached, for a total of $156 \mathrm{mAh} / \mathrm{g}$ [69]. The cubic symmetry is maintained until about $\mathrm{Li}_{6.5} \mathrm{Mn}_{5} \mathrm{O}_{12}$, at which point $\mathrm{Mn}$ is reduced to an average oxidation state of 3.5 and the cooperative Jahn-Teller effect induces a tetragonal distortion. Because this process occurs only at the end of discharge, $\mathrm{Li}_{4} \mathrm{Mn}_{5} \mathrm{O}_{12}$ exhibits much better cycling behavior on the $3 \mathrm{~V}$ plateau than does $\mathrm{LiMn}_{2} \mathrm{O}_{4}$. However, the low operating voltage and capacity, and the inability to extract lithium makes $\mathrm{Li}_{4} \mathrm{Mn}_{5} \mathrm{O}_{12}$ impractical for Li-ion batteries.

It is also possible to prepare cation-deficient or defect spinels, $\mathrm{Li}_{1-x} \mathrm{Mn}_{2-2 x} \mathrm{O}_{4}$ [69a]. The cation vacancies increase the average oxidation state of $\mathrm{Mn}$ and decrease the capacity above $4 \mathrm{~V}$ in favor of that below $3 \mathrm{~V}$, proportionally with $\mathrm{x}$. In the end-member compound $\mathrm{Li}_{2} \mathrm{Mn}_{4} \mathrm{O}_{9}$ (corresponding to $\mathrm{x}=0.11$ in $\mathrm{Li}_{1-\mathrm{x}} \mathrm{Mn}_{2-}$ ${ }_{2 \times} \mathrm{O}_{4}$ ), all $\mathrm{Mn}$ is tetravalent, and lithium cannot be extracted, so that there is no capacity at $4 \mathrm{~V}$. Lithium can be inserted below $3 \mathrm{~V}$ vs. $\mathrm{Li}^{\prime} \mathrm{Li}^{+}$, to a maximum composition of $\mathrm{Li}_{5} \mathrm{Mn}_{4} \mathrm{O}_{9}$. Although the theoretical capacity $(213 \mathrm{mAh} / \mathrm{g})$ is higher than that of $\mathrm{Li}_{4} \mathrm{Mn}_{5} \mathrm{O}_{12}$, approximately $1 / 3$ of it is associated with formation of the Jahn-Teller distorted tetragonal phase.

In principle, defect spinels with values of $x<0.11$ should cycle on the $4 \mathrm{~V}$ plateau better than $\mathrm{LiMn}_{2} \mathrm{O}_{4}$ for the same reasons as the lithium-rich stoichiometric spinels. In practice, it is difficult to control the degree of nonstoichiometry during synthesis, so these materials are not of interest commercially.

In spite of the improved performance exhibited by the lithium-substituted spinels, capacity fading upon cycling is still observed in electrochemical cells, particularly at elevated temperatures $\left(55^{\circ} \mathrm{C}\right)$ [70]. This has negative 
implications particularly for vehicular applications, where batteries may be subjected to a wide variety of operating and storage conditions, including very warm environments. The dissolution is associated with $\mathrm{Mn}^{3+}$ disproportionation (equation 2) in the presence of acidic components of the $\mathrm{LiPF}_{6} /$ organic carbonate electrolyte solutions used in Li-ion batteries.

$2 \mathrm{Mn}^{3+}($ solid $) \rightarrow \mathrm{Mn}^{4+}($ solid $)+\mathrm{Mn}^{2+}$ (solution)

Loss of manganese leads to the formation of a defect spinel structure with reduced or no $4 \mathrm{~V}$ capacity $[65,70]$. Additionally, proton exchange [70], phase separation, film formation, and precipitation of $\mathrm{MnO}$ and $\mathrm{MnF}_{2}$ may occur, increasing cell impedance and exacerbating the capacity fading. More significantly, dissolved $\mathrm{Mn}^{2+}$ can cross over to the anode, become reduced and precipitate as the metal, increasing the charge-transfer resistance and disrupting the critical SEI layer [71]. The graphite anode is markedly more sensitive to this effect than lithium is. Thus, assessment of spinel cathodes to determine the effectiveness of an approach to improve resistance to dissolution should ultimately be carried out in a full cell configuration rather than in lithium half-cells.

Some methods designed to address the problem of spinel dissolution include coating of particles [72] and the use of new non-fluorinated salts such as lithium bis(oxalato)borate (LiBOB) which do not generate HF in situ [73]. Interestingly, dissolution of manganese appears to be suppressed in electrodes where LMO is mixed with an NMC [74]. Although the cycling behavior of Li-ion cells with spinel electrodes is still inferior to that of devices containing alternative commercial cathode materials (Table 2), other aspects of performance such as 
rate capability and safety $[19,75]$, the wide availability of manganese precursors, and the potential for low cost, make LMO attractive especially for vehicular applications. Thus, at least one battery manufacturer focused on vehicle technologies (e.g., Enerdel, Indianapolis, IN) is pursuing the development of Li-ion batteries with spinel cathodes and hard carbon anodes (which are less sensitive to the effects of manganese dissolution than graphite).

Several lithium-containing oxide spinels having transition metals other than $\mathrm{Mn}$ can also be synthesized. One example is $\mathrm{LiCo}_{2} \mathrm{O}_{4}$, which can be prepared from a low temperature form of $\mathrm{LiCoO}_{2}$ [76]. (The latter, known as $\mathrm{LT}^{\mathrm{L}} \mathrm{LiCoO}$, has a structure intermediate between that of a spinel and layered compound). Another is $\mathrm{LiNi}_{2} \mathrm{O}_{4}$ [15a]. Unlike $\mathrm{LiMn}_{2} \mathrm{O}_{4}$, the electrochemical characteristics of most of these spinels are inferior to those of the layered analogs, so that they are not of technological interest as cathode materials. However, $\mathrm{Li}_{4} \mathrm{Ti}_{5} \mathrm{O}_{12}$ (LTO), which, because of its voltage properties, functions as an anode material, demonstrates excellent cycling performance. Although the energy density is lower than that of graphite, it does not require formation of an SEI. Thus, it is also an attractive match for LMO cathode materials. Batteries with LTO anodes and LMO or other high voltage cathodes may find utility in HEVs, which do not require as high an energy density as pure EVs.

The intensive search for substituted lithium manganese spinels with better cycling performance led to the discovery of several materials having capacity near $5 \mathrm{~V}$ vs. $\mathrm{Li} / \mathrm{Li}^{+}$. These include spinels substituted with $\mathrm{Cr}, \mathrm{Fe}, \mathrm{Cu}, \mathrm{Co}$, or $\mathrm{Ni}$ [77]. In most cases, these materials exhibit a plateau near $4 \mathrm{~V}$ as well as a second plateau near $5 \mathrm{~V}$, with the magnitude of the latter increasing with larger $\mathrm{x}$ in $\mathrm{LiM}_{\mathrm{x}} \mathrm{Mn}_{2-\mathrm{x}} \mathrm{O}_{4}$ (where $\mathrm{M}=\mathrm{Cr}, \mathrm{Fe}, \mathrm{Cu}, \mathrm{Co}$, or $\mathrm{Ni}$ ). The $4 \mathrm{~V}$ capacity is associated with the usual $\mathrm{Mn}^{3+} / \mathrm{Mn}^{4+}$ spinel redox couple, whereas the higher voltage 
plateau is associated with redox processes of the substituting metal. Interestingly, the compound $\mathrm{LiNi}_{1 / 2} \mathrm{Mn}_{3 / 2} \mathrm{O}_{4}$ has very little $4 \mathrm{~V}$ capacity, unlike other $\mathrm{LiM}_{1 / 2} \mathrm{Mn}_{3 / 2} \mathrm{O}_{4}$ spinels [78] (Figure 7).
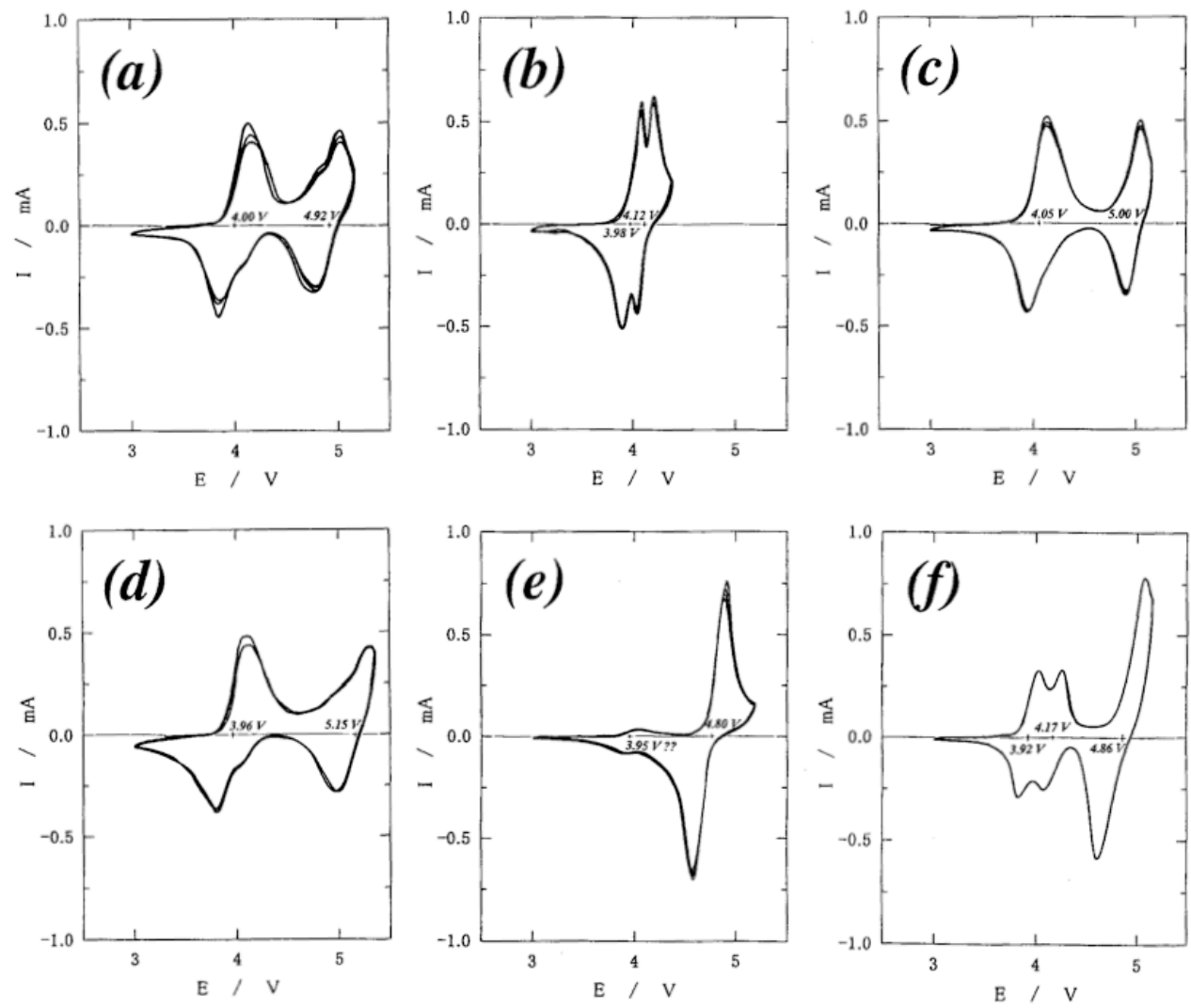

Figure 7. Slow-scan voltammetry of $\mathrm{Li} / \mathrm{LiM}_{1 / 2} \mathrm{Mn}_{3 / 2} \mathrm{O}_{4}$ cells with $\left.\mathrm{M}=\mathrm{a}\right) \mathrm{Cr}$, b) $\mathrm{Mn}$, c) $\mathrm{Fe}, \mathrm{d}$ ) $\mathrm{Co}, \mathrm{e}) \mathrm{Ni}$, and f) $\mathrm{Cu}$ at a rate of $0.2 \mathrm{mV} / \mathrm{sec}$ using $1 \mathrm{M} \mathrm{LiPF} 6$ in $1: 1 \mathrm{v} / \mathrm{v}$ EC/DEC electrolyte. Used with permission from reference 78.

In the case of $\mathrm{LiNi}_{1 / 2} \mathrm{Mn}_{3 / 2} \mathrm{O}_{4}$, nearly all of the $\mathrm{Mn}$ is tetravalent [77e], so that further oxidation is not possible. The specific capacity of $147 \mathrm{mAh} / \mathrm{g}$ at $4.7 \mathrm{~V}$ is associated with $\mathrm{Ni}^{2+} / \mathrm{Ni}^{4+}$ redox processes. The high energy density and high voltage makes this material attractive for vehicular applications, because fewer cells need to be connected in series to make the $300 \mathrm{~V}$ packs used in electric 
vehicles. This simplifies engineering, results in comparatively higher energy density on the system level because less hardware is required, and lowers costs. ETV Motors of Herzliya, Israel is one company actively developing $\mathrm{LiNi}_{1 / 2} \mathrm{Mn}_{3 / 2} \mathrm{O}_{4}$ batteries for this purpose.

The very high potential at which this cathode operates, however, presents considerable challenges for cycle life. Although conventional carbonate-based electrolytes used in Li-ion batteries have, in principle, excellent oxidative stability, the presence of impurities such as water may contribute to side reactions that decrease resistance to irreversible oxidation, resulting in shortened battery lifetimes. In addition, cell components such as carbon additives used to improve conductivity in composite cathodes, or surfactants that aid in wetting may oxidize irreversibly at high potentials, and current collectors may corrode. Thus, cycling is usually restricted to a voltage range below about $4.3 \mathrm{~V}$ vs. $\mathrm{Li} / \mathrm{Li}^{+}(4.2 \mathrm{~V}$ in cells with graphite anodes). Stringent purification of electrolytes and the use of special protective additives are allowing gradual extension of this range. In addition, development of new electrolytes containing ionic liquids or sulfolanes are expected to enable high voltage cell operation, although the choice of anode may then be restricted to LTO or other materials that do not require SEI formation. Other strategies to prolong the cycle life of cells containing $\mathrm{LiNi}_{1 / 2} \mathrm{Mn}_{3 / 2} \mathrm{O}_{4}$ include treating active material particles with protective coatings to minimize direct contact with electrolyte solutions [79], or partial substitution of $\mathrm{Ni}$ or $\mathrm{Mn}$ with other cations such as $\mathrm{Ti}, \mathrm{Mg}$, or $\mathrm{Zn}[80]$.

Synthesis of $\mathrm{LiNi}_{1 / 2} \mathrm{Mn}_{3 / 2} \mathrm{O}_{4}$ is normally carried out at high temperatures to ensure good crystallinity and to lower the surface area and thus minimize reactivity with electrolyte solutions and other components. Under these 
conditions, oxygen loss may occur, leading to formation of a non-stoichiometric material $\left(\mathrm{LiNi}_{1 / 2} \mathrm{Mn}_{3 / 2} \mathrm{O}_{4-\mathrm{x}}\right)$ containing some $\mathrm{Mn}^{3+}$ in the structure. Additionally, a rock salt impurity, $\mathrm{Li}_{x} \mathrm{Ni}_{1-\mathrm{x}} \mathrm{O}$ is also produced. Annealing at $700^{\circ} \mathrm{C}$ partially reverses the oxygen loss, but the telltale $4 \mathrm{~V}$ capacity indicative of the presence of electro-active $\mathrm{Mn}^{3+}$ can often be observed in cells made with these materials (e.g., in Figure 4e). Substitution with other metals, as discussed in the papers listed in reference 80 , often decreases the amount of $\mathrm{Mn}^{3+}$ in these compounds, which may play a role in the observed improvements in cycling.

If the sample is cooled slowly during synthesis, an ordered phase can be produced (space group $\mathrm{P}_{3} 32$ with $\mathrm{Ni}$ in $4 b$ sites and $\mathrm{Mn}$ in $12 d$ sites [81). The electrochemical properties (in particular, rate capability) of the ordered phase are inferior to those of the disordered non-stoichiometric phase [82]. The mixed Mn valency in the disordered $F d-3 m$ phase leads to an increase in the electronic conductivity of about 1.5 orders of magnitude compared to that of the ordered material. This is thought to be responsible for the increased rate capability of the former compared to the latter.

The presence of electro-active $\mathrm{Mn}$ in disordered $\mathrm{LiNi}_{1 / 2} \mathrm{Mn}_{3 / 2} \mathrm{O}_{4}$ suggests that dissolution may be problematic, as it is with the $\mathrm{LiMn}_{2} \mathrm{O}_{4}$ variants. In spite of this and the high operating voltages, extremely stable cycling has been observed in full cell configurations, albeit with $\mathrm{Li}_{4} \mathrm{Ti}_{5} \mathrm{O}_{12}$ anodes [83].

\section{$\mathrm{LiFePO}_{4}$ and other phospho-olivines}

In 1997, Goodenough and co-workers reported on the electrochemical properties of a new class of cathode materials known as the phospho-olivines [84], which adopt the orthorhombic structure (space group Pnma) shown in Figure 2c. In the case of $\mathrm{LiFePO}_{4}$ (triphylite), $\mathrm{Li}^{+}$and $\mathrm{Fe}^{2+}$ occupy octahedral 
sites, and $\mathrm{P}$ is located in tetrahedral sites in a somewhat distorted hexagonal close-packed (hcp) oxygen array. The $\mathrm{FeO}_{6}$ octahedra share corners and $\mathrm{LiO}_{6}$ octahedra share edges along tunnels down the $b$-axis, through which the Li ions can diffuse. Extraction and re-insertion of $\mathrm{Li}$ from $\mathrm{LiFePO}_{4}$ proceeds at about $3.45 \mathrm{~V}$ in a lithium cell with a theoretical specific capacity of $170 \mathrm{mAh} / \mathrm{g}$. The potential is independent of the composition $x$ in $\mathrm{Li}_{x} \mathrm{FePO}_{4}$ (i.e., the voltage profile is flat, Figure 3 ) indicating that a two-phase reaction occurs. In situ X-ray diffraction and Mossbauer experiments on $\mathrm{Li}^{2} \mathrm{LiFePO}$ cells [85] show that the two relevant phases are triphylite and $\mathrm{FePO}_{4}$, also known as heterosite (equation 3).

$\mathrm{LiFePO}_{4}$ (triphylite) $\leftrightarrow \mathrm{FePO}_{4}$ (heterosite) $+\mathrm{e}^{-}+\mathrm{Li}^{+}$

Initial reports on the electrochemical characteristics of $\mathrm{LiFePO}_{4}$ emphasized its poor rate capability and the lower than expected utilization in lithium cells even when discharged at low current densities (for example, only about $60 \%$ in reference 85). This was attributed to the low electronic conductivities of both the triphylite and heterosite phases [86]. Carbon-coating particles ameliorates the low conductivity and results in better rate performance [87]. This is most conveniently achieved by including a carbon source during initial synthesis of the $\mathrm{LiFePO}_{4}$ sample. The presence of carbon or carbon-containing precursors during calcination in an inert atmosphere has several additional beneficial effects; it retards grain growth, resulting in small particles that allow rapid extraction of $\mathrm{Li}$ ions, and prevents formation of $\mathrm{Fe}^{3+}$-containing impurities. It also allows the use of easy-to-handle, low-cost, $\mathrm{Fe}^{3+}$-containing starting materials such as iron nitrate, which are reduced during the heating process [88]. 
In practice, many lab-synthesized samples of $\mathrm{LiFePO}_{4}$ contain carbon, due to the use of precursors such as iron oxalate [89]. Even small amounts of carbon can result in drastic sample color changes from the off-white of native $\mathrm{LiFePO}_{4}$ (Figure 8 ). The electrochemical performance is also greatly affected by the carbon content, although this also depends on the distribution of carbon over particle surfaces and details of its structure [90]. Carbons produced in situ during synthesis of $\mathrm{LiFePO}_{4}$ are disordered due to the relatively low calcination temperatures (generally, $600-700^{\circ} \mathrm{C}$ ). Disordered carbons are less conductive than graphite, and conductivity depends on the size and number of graphene domains. The use of graphitization catalysts (often containing iron) improves the conductivity of coatings by several orders of magnitude, and can also result in co-production of carbon nanotubes or fibers, which wire particles together [91]. The result is that very small amounts of carbon, often less than 2 wt. \%, are sufficient to produce high-rate $\mathrm{LiFePO}_{4}$ samples. This is important because too much lightweight carbon adversely affects the tap densities of $\mathrm{LiFePO}_{4}$ composites, further decreasing the already somewhat low energy density [92].

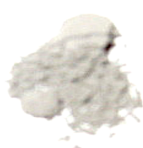

$0.3 \% \mathrm{C}$

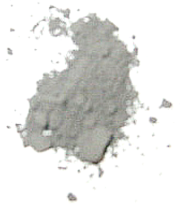

$0.7 \% \mathrm{C}$

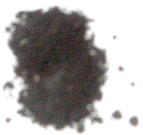

$1.15 \% \mathrm{C}$

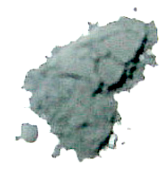

$1.5 \% \mathrm{C}$

Figure 8. Photographs of $\mathrm{LiFePO}_{4}$ samples containing varying amounts of carbon. Used with permission from reference 89.

The changes in sample color, increases in bulk conductivities, and improved electrochemical performance induced by the presence of very small amounts of 
carbon (or other highly colored impurities) complicate interpretation of results of doping experiments intended to increase the intrinsic conductivity of $\mathrm{LiFePO}_{4}$. A color change from off-white to black or gray should not be regarded as proofpositive of successful doping and increased intrinsic electronic conductivity, for the reasons described above. Even when carbonaceous precursors are not used, the use of organic solvents or plastic containers during grinding or other processing steps may introduce carbon. Early claims of successful low-level aliovalent substitution [93] on the $\mathrm{Li}$ sites of $\mathrm{LiFePO}_{4}$, resulting in greatly enhanced conductivities and electrochemical performance, may have been a fortuitous consequence of well-distributed electronically conductive impurities such as carbon and metal-rich phosphides [94]. Recent studies of the defect chemistry of $\mathrm{LiFePO}_{4}$ show that substitution of multivalent ions on the $\mathrm{Li}$ site is very limited, and always accompanied by lithium vacancies, so that no mixed valency for iron occurs [95]. Earlier computational modeling of the defect, dopant, and $\mathrm{Li}$ transport properties of $\mathrm{LiFePO}_{4}[96]$ indicates that substitution of multivalent ions on $\mathrm{Li}$ or Fe sites (other than divalent ions on the latter) is not energetically favored. It was predicted that the most likely type of defect is the $\mathrm{Li}-\mathrm{Fe}$ anti-site pair, in which $\mathrm{Li}^{+}$ions are located on $\mathrm{Fe}^{2+}$ sites and are balanced by an equal number of $\mathrm{Fe}^{2+}$ ions on $\mathrm{Li}$ sites. Recent work, however, shows that there is a marked asymmetry between the number of Fe ions on Li sites and vice versa [97]. Very few lithium atoms can be accommodated on iron sites. More commonly, Fe ions on Li sites are accompanied by a small number of vacancies, to form $\left[\mathrm{Li}_{1-2 x} \mathrm{Fe}_{\mathrm{x}}\right] \mathrm{FePO}_{4}$. The presence of relatively immobile multivalent ions on $\mathrm{Li}$ sites interferes with fast $\mathrm{Li}$ diffusion, since $\mathrm{LiFePO}_{4}$ is essentially a one-dimensional ion conductor [98]. Likewise, a large number of anti-site defects are likely to impact electrochemical performance adversely [99] 
as is seen in reference 97. At any rate, it is apparent that near room temperature, only a relatively small concentration of vacancies or interstitial defects is possible.

Carbon coatings, although convenient for the reasons state above, are not absolutely necessary to assure good electrochemical performance [100], as long as particle sizes are kept small and particle size distributions are narrow. Nanostructuring reduces diffusion distances and ameliorates the effects of low electronic conductivity, allowing full discharge at even moderate to high rates. Subtle changes in the discharge characteristics of $\mathrm{LiFePO}_{4}$ samples occur as particle size is decreased; most notably, a stronger dependence of voltage upon composition ( $x$ in $\mathrm{Li}_{x} \mathrm{FePO}_{4}$ ) close to the end-of-charge and end-of-discharge, implying solid-solution behavior [101]. Other researchers have observed XRD, neutron diffraction, and electrochemical evidence of a small degree of lithium non-stoichiometry in larger $\mathrm{Li}_{x} \mathrm{FePO}_{4}$ particles at both composition extremes [102], as illustrated in Figure 9. 


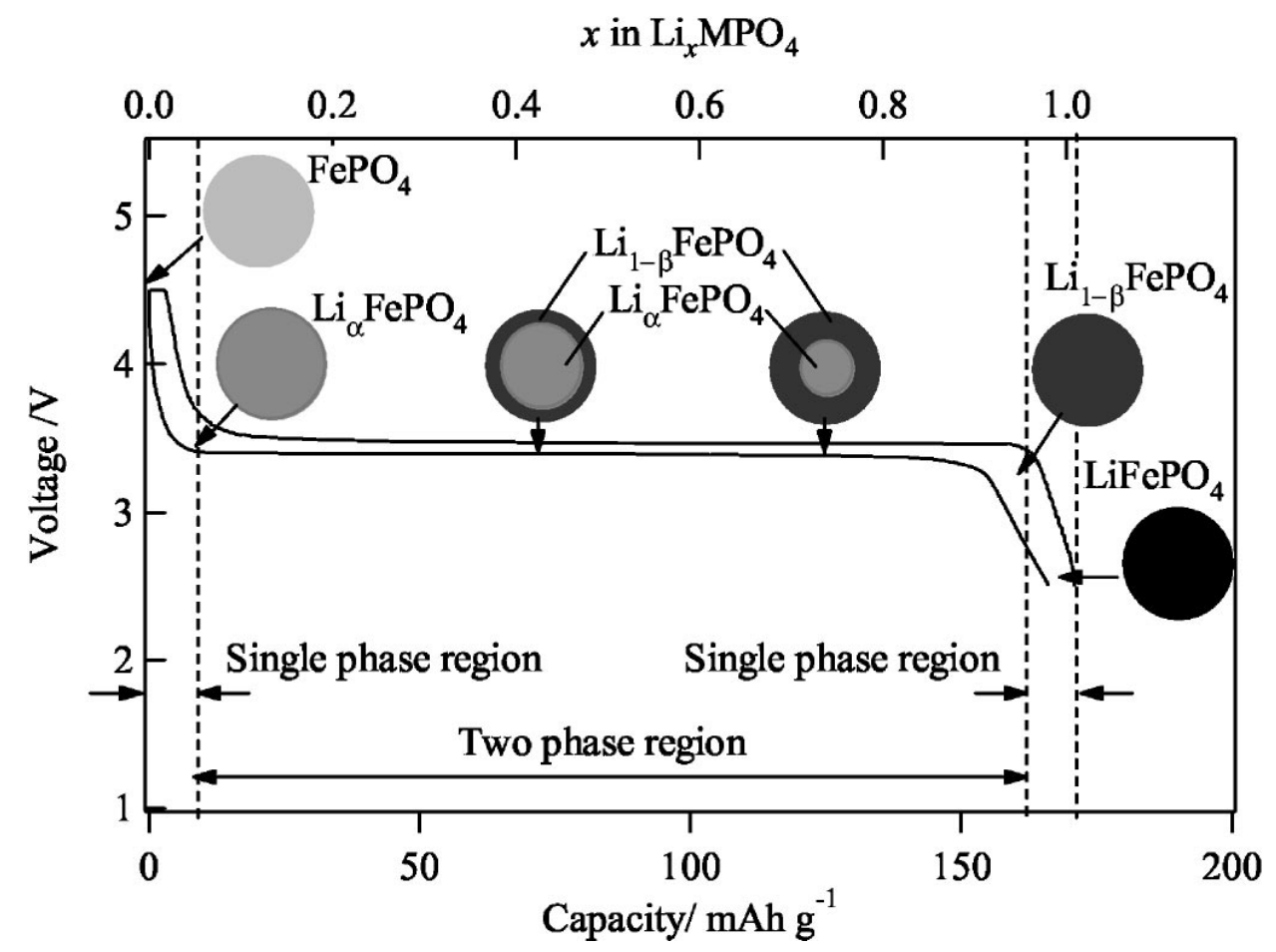

Figure 9. Scheme of the discharge processes of $\mathrm{Li}_{x} \mathrm{FePO}_{4}$, showing solidsolution behavior close to $x=0$ and $x=1$. Used with permission from reference $102 a$

The existence of a small degree of non-stoichiometry (and thus mixed valence states for iron) may explain why this system is electro-active, given that both end-members have such poor electronic conductivity. It should be noted, however, that kinetic effects, surface impurities, and the presence of defects [101b, 103] also influence the shape of the $\mathrm{Li}^{2} \mathrm{LiFePO}{ }_{4}$ discharge profile. This makes it hard to determine what the exact compositional ranges of solid-solution behavior are at room temperature from the electrochemical data alone. Complications from the effects of strain also make interpretation of diffraction data difficult.

Experiments conducted on heated $\mathrm{LiFePO}_{4} / \mathrm{FePO}_{4}$ mixtures of varying concentrations [104], show that solid solutions form from $0 \leq x \leq 1$ in $\mathrm{Li}_{x} \mathrm{FePO}_{4}$ at 
elevated temperatures, however. A representative phase diagram is shown in Figure 10. The solubility limits of lithium in heterosite and vacancies in triphylite are approximated in the figure, because of the uncertainties outlined above. Additionally, due to slow kinetics, the exact temperature boundaries are not known exactly, explaining the slight differences observed by various researchers. Depending upon the initial concentration, and details of the crystal sizes and morphologies, metastable lithium-deficient phases can persist for remarkably long times after cooling [105].

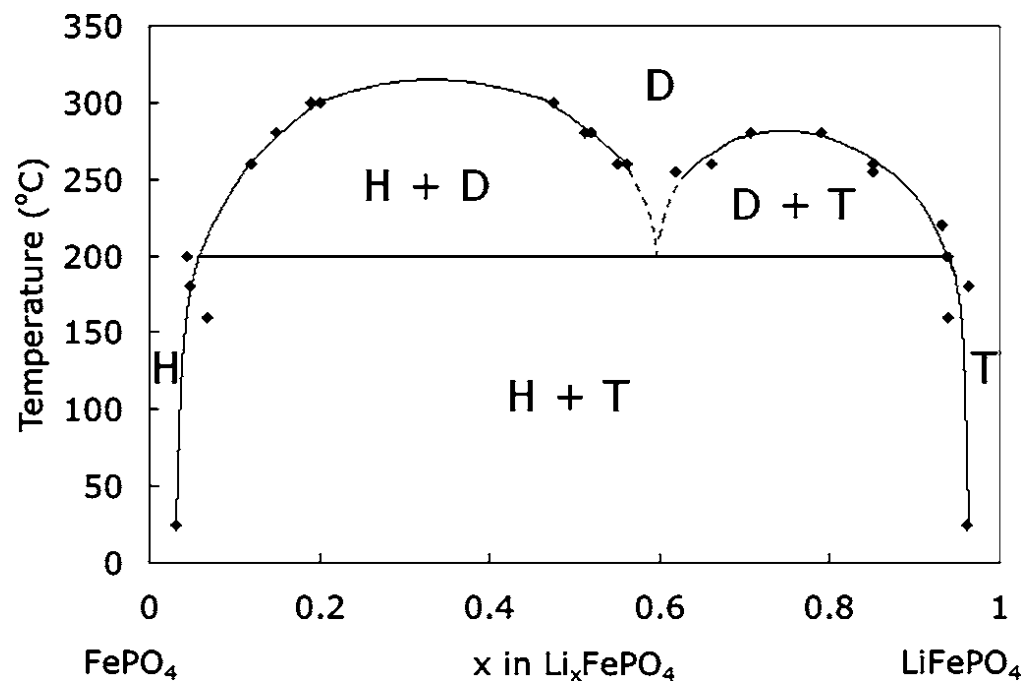

Figure 10. Phase diagram of the $\mathrm{Li}_{x} \mathrm{PO}_{4}$ system, where $\mathrm{T}, \mathrm{H}$, and $\mathrm{D}$ denote triphyllite, heterosite, and disordered (but not amorphous) phases, respectively. Used with permission from reference 104b.

The mechanism of the $\mathrm{LiFePO}_{4} / \mathrm{FePO}_{4}$ electrochemical reaction has been described using a shrinking core model [106], as depicted in Figure 9. During discharge, lithium initially inserts into $\mathrm{FePO}_{4}$ to form the solid-solution $\mathrm{Li}_{\alpha} \mathrm{FePO}_{4}$ phase, where $\alpha$ is close to 0 . Upon further passage of current, a shell of a 
lithium-rich material $\left(\mathrm{Li}_{1-\beta} \mathrm{FePO}_{4}\right)$ is produced on the surface, over a core of $\mathrm{Li}_{\alpha} \mathrm{FePO}_{4}$. As the reaction continues to progress, the shell grows at the expense of the core, and the interface between the two phases shrinks, until complete conversion to $\mathrm{Li}_{1-\beta} \mathrm{FePO}_{4}$ occurs. Further lithiation produces $\mathrm{LiFePO}_{4}$ at the end of discharge. The entire process is reversed upon charge. The anisotropy of lithium diffusion in $\mathrm{LiFePO}_{4}$ [98], however, complicates the interpretation of the shrinking core model. A transmission electron microscopy (TEM) study of partially delithiated large plate-like particles [107] show that ordered domains of $\mathrm{FePO}_{4}$ and $\mathrm{LiFePO}_{4}$ alternate in the ac plane, separated by narrow disordered (but not amorphous) regions, where lithium mobility is enhanced. The phase transformation proceeds in the direction of the a-axis at dislocation lines that run parallel to the $c$-axis, consistent with one-dimensional $\mathrm{Li}^{+}$diffusion in the $b$ direction (Figure 11). This somewhat resembles an early "mosaic" model proposed by Andersson et al. as an alternative to the shrinking core model [108]. These observations also suggest that the best rate performance can be achieved with particles that are thin in the direction of Li diffusion (b-axis), but that nanostructuring in other directions may not be required.

In another recent study [109] using high-resolution electron energy loss spectroscopy (EELS) on a chemically prepared sample, a different distribution of the two phases in a partially delithiated particle was observed. In this case, $\mathrm{LiFePO}_{4}$ was present only at the edges with $\mathrm{FePO}_{4}$ located in the interior (but not on surfaces of the ac planes) of plate-like particles significantly smaller than those studied in reference 107 . This is consistent with a progressive emptying or filling of $\mathrm{Li}$ channels oriented along the $b$-axis, with the front between the two phases moving perpendicular to the ac plane. No disordered regions at the 
phase boundaries were detected, however. This lack of evidence for solidsolution behavior argues against a shrinking core mechanism, which requires that at least a small degree of non-stoichiometry exist in the system.

Variations in particle sizes and morphologies, as well as in the concentration of defects, may well influence the progression of the delithiation reaction during chemical oxidation and explain these differing results. In electrochemical cells with composite electrodes, the reaction may nucleate preferentially at sites where contact with conductive carbon additives or coatings and the electrolyte solution is the closest, leading to a different pattern of phase distributions than is seen in the chemically delithiated samples, where nucleation can occur at numerous sites simultaneously. In partially delithiated $\mathrm{Li}_{x} \mathrm{FePO}_{4}$ samples recovered from electrochemical cells, no mixed-phase nanoparticles were observed, leading the researchers to surmise that the reaction front propagates much more rapidly than nucleation [110]. A recent kinetic study also indicates that the $\mathrm{LiFePO} / \mathrm{FePO}_{4}$ transformation is controlled by a phase-boundary reaction [111]. However, newly discovered evidence of intercrystallite ionic transport, leading to a redox reaction between delithiated and lithiated particles and subsequent equilibration [112] complicates interpretation of these results. Moreover, areas of composite electrodes with poor electronic connectivity may be electrochemically inactive, leading to islands of unreacted $\mathrm{LiFePO}_{4}$. In that case, all of the lithium will be extracted from $\mathrm{LiFePO}_{4}$ in better connected areas, and mixtures of $\mathrm{FePO}_{4}$ and $\mathrm{LiFePO}_{4}$ will be observed, as in reference 110 .

While the actual mechanism of the $\mathrm{LiFePO} / / \mathrm{FePO}_{4}$ transformation remains a subject of debate, it seems clear that the shrinking core model does not apply to the primary particles themselves. The model may, however, still be applicable on a larger scale, e.g., to the secondary particles comprised of agglomerates. 

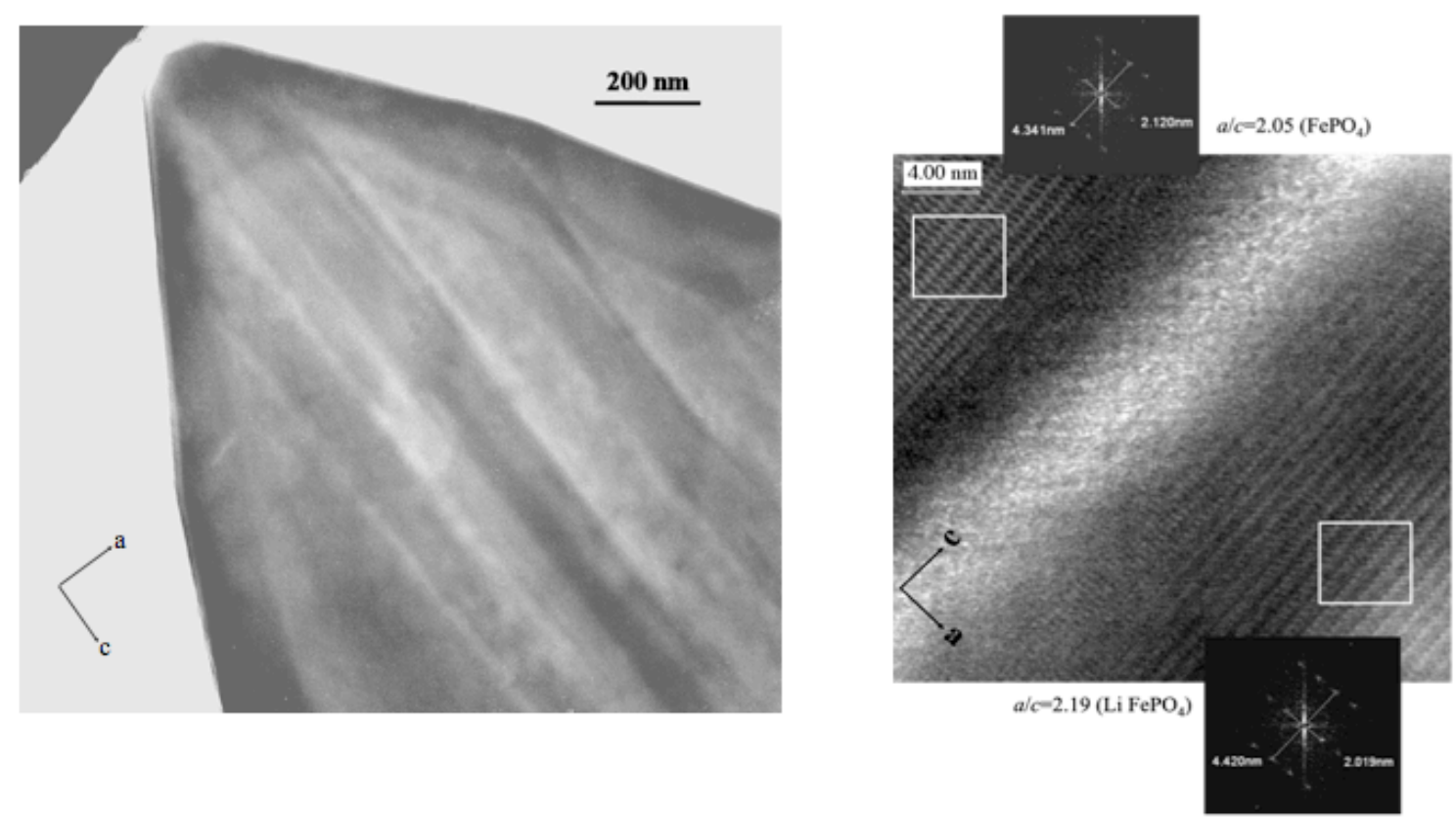

Figure 11. Left: TEM image showing a partially delithiated crystal with the global composition $\mathrm{Li}_{0.5} \mathrm{FePO}_{4}$, showing domains of $\mathrm{LiFePO}_{4}$ and $\mathrm{FePO}_{4}$ aligned along the c-axis. Right: High-resolution TEM image with Fourier transforms of the boxed areas, identifying the two phases. Used with permission from reference 107.

Over the past decade, better control of synthesis parameters, the use of conductive coatings, and nanostructuring have transformed $\mathrm{LiFePO}_{4}$ from a poorly performing material to one of the most attractive cathodes for Li-ion batteries. $\mathrm{LiFePO}_{4}$ appears to be particularly well suited to high power applications including power tools and vehicle propulsion. A recent study shows that extraordinarily high charge and discharge currents can be sustained in cells designed so that a modified $\mathrm{LiFePO}_{4}$ limits rate [113]. (While these devices are 
not practical for real-world use, they serve to demonstrate the intrinsic rate capability of $\mathrm{LiFePO}_{4}$ without interference from mass transfer limitations in other cell components). There have been reports [114] of iron dissolution in $\mathrm{LiPF}_{6}$ containing electrolytes leading to capacity fading at elevated temperatures (analogous to the problems observed with manganese oxide spinels), although this may be due to the presence of iron-containing surface impurities such as $\mathrm{Fe}_{2} \mathrm{P}$ rather than to the $\mathrm{LiFePO}_{4}$ itself. The thermal properties of the $\mathrm{LiFePO}_{4} / \mathrm{FePO}_{4}$ system are a particularly attractive feature, leading to enhanced safety (LFP, Table 2). Upon heating, $\mathrm{FePO}_{4}$ produced by charging $\mathrm{LiFePO}_{4}$ transforms to the thermodynamically favored trigonal form ( $\alpha$-quartz structure). While this reaction is irreversible and leads to loss of capacity, it progresses without evolution of oxygen [115]. This is in contrast to transition metal oxides, all of which lose oxygen to some degree at high states-of-charge. This makes this cathode especially appealing for traction applications, where safety is paramount.

Because $\mathrm{LiFePO}_{4}$ is less dense than the layered oxides or spinels (the crystallographic density is $3.6 \mathrm{~g} / \mathrm{cm}^{3}$ compared to about $5 \mathrm{~g} / \mathrm{cm}^{2}$ for the oxides), and the potential vs. lithium is lower, the energy density is less than that of the oxides (Table 2). The specific energy, in contrast, is competitive with LMO (Table 1), but for many applications, the energy per unit volume matters more than per weight. The discharge potential of the iso-structural $\mathrm{LiMnPO}_{4}$ is about $0.5 \mathrm{~V}$ vs. $\mathrm{Li} / \mathrm{Li}^{+}$higher than that of $\mathrm{LiFePO}_{4}[116]$, which increases the specific energy by about $15 \%$. Unfortunately, this material is even less dense than $\mathrm{LiFePO}_{4}\left(3.4 \mathrm{~g} / \mathrm{cm}^{3}\right)$, and the conductivity appears to be several orders of magnitude lower [117]. Synthetic procedures used to produce nano-particulate $\mathrm{LiMnPO}_{4}$ and variants include sol-gel, precipitation, combustion techniques, 
spray pyrolysis, and hydrothermal or solvothermal (polyol process) methods [99b, 118]. For samples calcined in air for the sake of convenience, a fair amount of carbon is generally added after synthesis to offset the low conductivity. Coating can also be achieved via incorporation of carbonaceous precursors or elemental carbon during heat treatment under inert atmosphere, as with $\mathrm{LiFePO}_{4}$. Electrochemical performance improves as the average primary particle size decreases [119]. Partial Mg substitution on the $\mathrm{Mn}$ site is also beneficial [118f, 120]. This effect has been attributed to stabilization against strain associated with the Jahn-Teller distortion of $\mathrm{Mn}^{3+}$ ions in the delithiated phase, as well as decreased volume changes upon cycling. The best results reported so far have been for solvothermally prepared powders (polyol process) embedded in a carbon matrix [121]. Still, the rate capability of $\mathrm{LiMnPO}_{4}$ is not as impressive as that of $\mathrm{LiFePO}_{4}$, and many of the strategies employed to improve the electrochemistry (Mg-substitution, addition of large amounts of carbon, nanostructuring) reduce the already fairly small energy density advantage. The disappointing performance has been variously attributed to poor transport properties in either the bulk $\mathrm{LiMnPO}_{4}$ or $\mathrm{MnPO}_{4}$ phases, instability of the $\mathrm{MnPO}_{4}$ phase itself, or surface effects [117b, 122]. While the voltage profile of $\mathrm{LiMnPO}_{4}$ is flat during charge and discharge, indicating a two-phase process, evidence of solid-solution behavior near the $\mathrm{MnPO}_{4}$ limit has been observed [123]. As with the $\mathrm{LiFePO}_{4} / \mathrm{FePO}_{4}$ system, the non-stoichiometry may enable the electrochemical activity. However, no solid solution behavior near the $\mathrm{LiMnPO}_{4}$ end of the phase diagram has yet been detected.

Although the performance characteristics of the $\mathrm{LiMnPO}_{4} / \mathrm{MnPO}_{4}$ system may improve with further work, one troubling aspect of this electrode is its thermal instability in the charged state. Unlike $\mathrm{LiFePO}_{4}, \mathrm{MnPO}_{4}$ evolves oxygen 
gas upon heating to $200^{\circ} \mathrm{C}$ and decomposes to form $\mathrm{Mn}_{2} \mathrm{P}_{2} \mathrm{O}_{7}$ [124]. The instability of $\mathrm{MnPO}_{4}$ is probably related to the strong Jahn-Teller distortion of the $\mathrm{Mn}^{3+}$ ion. $\mathrm{LiMnPO}_{4}$ is therefore less attractive than $\mathrm{LiFePO}_{4}$ in terms of safety, and does not have better performance characteristics than the metal oxides. Charging is also somewhat problematic, because high over-potentials are required due to the kinetic limitations. Thus, it seems unlikely that this cathode material will prove useful for traction batteries in the near term, although other applications may be feasible.

Phospho-olivine compounds containing $\mathrm{Co}$ or $\mathrm{Ni}$ also exist. $\mathrm{LiCoPO}_{4}$ exhibits electrochemical activity at about $4.8 \mathrm{~V}$ vs. $\mathrm{Li}_{/} \mathrm{Li}^{+}$[125]. $\mathrm{LiNiPO}_{4}$ is predicted to discharge at about $5.1 \mathrm{~V}$ in a lithium cell, but appears to be nearly completely inactive [126]. Neither of these is likely to be used as cathodes for lithium ion batteries in the near-term in part because of the very high voltages needed to charge the materials, which present a number of practical problems.

Solid solutions containing a mixture of transition metals can be prepared over a wide composition range [99b]. $\mathrm{Li}\left[\mathrm{Mn}_{\mathrm{y}} \mathrm{Fe}_{1-\mathrm{y}}\right] \mathrm{PO}_{4}$ compounds exhibit two plateaus in the discharge profile at about 4.1 and $3.45 \mathrm{~V}$ vs $\mathrm{Li}^{\prime} / \mathrm{Li}^{+}$with their relative magnitudes proportional to the amounts of $\mathrm{Mn}$ and Fe, respectively [84]. In general, for $\mathrm{y}<0.8$, the mixed metal phospho-olivines appear to undergo more facile electrochemical reactions than the pure end-member phase, $\mathrm{LiMnPO}_{4}$ $[122 b, 127]$. A study of the delithiation reactions of these phases [128] suggested that the system was single phase when $x<1-y$, but biphasic over the 4.1V plateau (corresponding to the $\mathrm{Mn}^{2+} / \mathrm{Mn}^{3+}$ redox couple). A later synchroton diffraction study [129] showed two two-phase regions roughly coinciding with the two plateaus and a narrow solid-solution region between $x=0.55$ and 0.67 for 
$\mathrm{Li}_{\times} \mathrm{Mn}_{0.6} \mathrm{Fe}_{0.4} \mathrm{PO}_{4}$, corresponding to the steeply sloping portion of the discharge profile between the plateaus.

Other mixed transition metal phospho-olivines have been prepared containing $\mathrm{Ni}$ and $\mathrm{Co}[125 \mathrm{~b}]$ and $\mathrm{Fe}, \mathrm{Mn}$, and $\mathrm{Co}[130]$. In the case of the $\mathrm{Li}\left[\mathrm{Ni}_{\mathrm{y}} \mathrm{Co}_{1-y}\right] \mathrm{PO}_{4}$, only one plateau was observed at $4.8 \mathrm{~V}$, corresponding to the $\mathrm{Co}^{2+} / \mathrm{Co}^{3+}$ redox couple. The only effect of the $\mathrm{Ni}$ substitution is to reduce the overall capacity, demonstrating the poor electro-activity of $\mathrm{Ni}$ in the phosphoolivine structure. In lithium cells containing $\mathrm{LiMn}_{1 / 3} \mathrm{Fe}_{1 / 3} \mathrm{Co}_{1 / 3} \mathrm{PO}_{4}$, on the other hand, three distinct electrochemical features are observed, corresponding to redox processes of the three types of transition metals (Figure 12). Interestingly, the reaction appears to be single phase over the entire composition range, $0 \leq x \leq 1$ in $\mathrm{LiMn}_{1 / 3} \mathrm{Fe}_{1 / 3} \mathrm{Co}_{1 / 3} \mathrm{PO}_{4}$, and the redox potentials of the $\mathrm{Fe}^{2+} / \mathrm{Fe}^{3+}$ and $\mathrm{Co}^{2+} / \mathrm{Co}^{3+}$ couples are slightly shifted compared to the corresponding $\mathrm{LiMPO}_{4}$ electrodes containing only one metal. The manganese redox processes appear to be more sluggish than those of iron and cobalt, and at higher discharge rates, the electrochemical feature at $4.1 \mathrm{~V}$ disappears. Tailoring of the voltage profile by incorporating multiple metals in the olivine structure may have practical use as a state-of-charge indicator for vehicular batteries (acting much like the gas gauge in conventional combustion engine automobiles). 


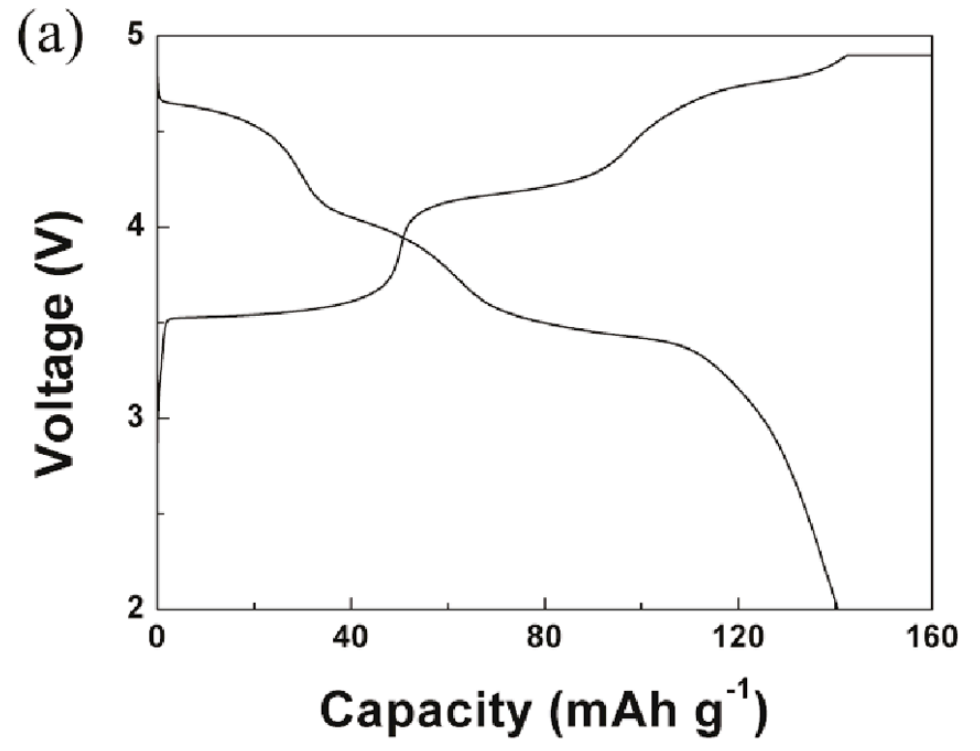

Figure 12. Charge and discharge of a $\mathrm{Li} / \mathrm{LiMn}_{1 / 3} \mathrm{Fe}_{1 / 3} \mathrm{Co}_{1 / 3} \mathrm{PO}_{4}$ cell, showing three distinct plateaus corresponding to the redox of Co (4.8V), Mn (4.1V), and Fe (3.45V). Used with permission from reference 130.

Other phosphates and polyanionic compounds

There are many other transition metal-containing poly-anionic compounds with structures amenable to lithium insertion processes. Among these are numerous materials with the Nasicon structure (Nasicon stands for sodium superionic conductor and originally referred to $\mathrm{Na}_{1+x} \mathrm{Zr}_{2} \mathrm{P}_{3-y} \mathrm{Si}_{y} \mathrm{O}_{12}$ compounds [131]). These have the general formula $A_{x} M_{2}\left(X_{4}\right)_{3}$, where $A$ is an alkali metal or alkaline earth, $\mathrm{M}$ is a transition metal or combination of transition metals, and $\mathrm{X}$ is $\mathrm{P}, \mathrm{As}, \mathrm{Si}$, or $\mathrm{S}$ or a combination of these. $\mathrm{M}$ is octahedrally coordinated by oxygen, and $\mathrm{X}$ is tetrahedrally coordinated. All corners of the $\mathrm{XO}_{4}$ tetrahedra are shared with $\mathrm{MO}_{6}$ octahedra and vice versa; these link to form open channels in which the alkali metal or alkaline earth ions are located. There are also closely related 3-dimensional framework structures with differing 
arrangements of corner-sharing polyhedra and distributions of alkali metal cations, such as the monoclinic $\mathrm{Li}_{3} \mathrm{Fe}_{2}\left(\mathrm{PO}_{4}\right)_{3}$ shown in Figure 13.

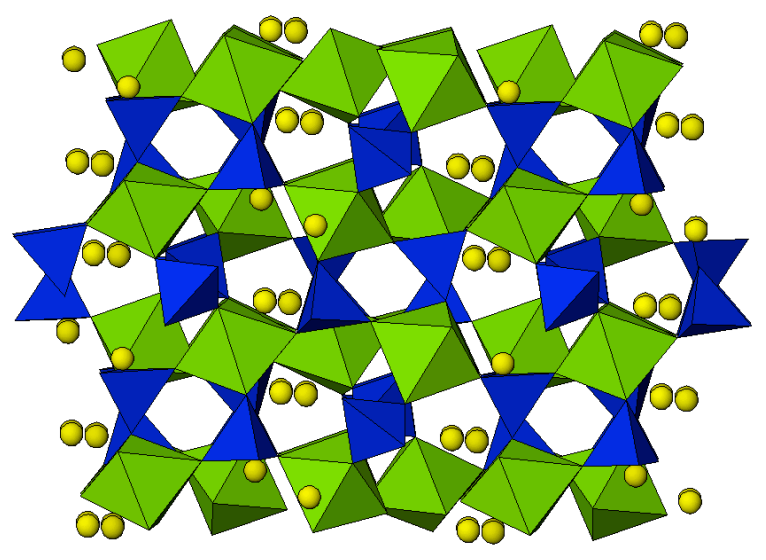

Figure 13. The structure of monoclinic $\mathrm{Li}_{3} \mathrm{Fe}_{2}\left(\mathrm{PO}_{4}\right)_{3}$ looking down the unique axis. $\mathrm{P}$ is located in the blue tetrahedra, and Fe in the green octahedra. Li ions are represented as spheres.

Transport of alkali metal ions through the tunnels in Nasicons can be extremely rapid, particularly at elevated temperatures, although the electronic conductivities are low. For these reasons, these materials were originally proposed for use as solid ionic conductors (e.g., to replace $\beta$ " alumina in high temperature $\mathrm{Na} / \mathrm{S}$ batteries). In spite of their low electronic conductivities, researchers recognized that Nasicon structures with redox-active transition metals and related 3D framework compounds could function as electrode materials as early as the late 1980s [132] and numerous materials were investigated [133]. In many cases, the electrochemical properties are unsuitable for $\mathrm{Li}$ ion batteries. For example, $\mathrm{Li}$ cannot be extracted from monoclinic $\mathrm{Li}_{3} \mathrm{Fe}_{2}\left(\mathrm{PO}_{4}\right)_{3}$, only inserted, and the discharge occurs at a rather low voltage 
(2.8V vs $\left.\mathrm{Li} / \mathrm{Li}^{+}\right)$. In contrast, up to two lithiums per formula unit can be extracted reversibly from monoclinic $\mathrm{Li}_{3} \mathrm{~V}_{2}\left(\mathrm{PO}_{4}\right)_{3}$, corresponding to a capacity of about $130 \mathrm{mAh} / \mathrm{g}$ at an average potential of 3.8V [134]. Complex multi-phasic behavior is exhibited upon redox, resulting in multiple plateaus in the discharge profile. In spite of significant volume changes upon lithium insertion and extraction, the material shows very good cycling behavior.

Fluorophosphates are relatively rare, but have recently been studied for $\mathrm{Li}$ ion applications. The lithium in $\mathrm{LiVPO}_{4} \mathrm{~F}$ [135] can be extracted reversibly at a potential of about $4.2 \mathrm{~V}$ vs. $\mathrm{Li}^{\prime} \mathrm{Li}^{+}$. Interestingly, lithium can also be inserted at about $1.8 \mathrm{~V}$. Thus, a graphite-free lithium ion battery can be built, using $\mathrm{LiVPO}_{4} \mathrm{~F}$ as both the anode and the cathode! $\mathrm{Na}_{3} \mathrm{~V}_{2}\left(\mathrm{PO}_{4}\right)_{2} \mathrm{~F}_{3}$ [136], $\mathrm{Na}_{2} \mathrm{FePO}_{4} \mathrm{~F}$ [137], and $\mathrm{LiFePO}_{4} \mathrm{~F}$ [138] have also been investigated. The first two compounds were used as-is in electrochemical cells, and underwent ion exchange in situ. Although these cathodes eventually stabilize when used in lithium metal cell configurations and the cycling behavior is good, the presence of sodium in full cells with graphite anodes may disrupt the SEI layer and is therefore undesirable. Thus, these compounds will have to be ion-exchanged prior to use. In the case of $\mathrm{LiFePO}_{4} \mathrm{~F}$, the investigators saw some evidence that a small amount of lithium could be extracted (with concomitant oxidation of $\mathrm{Fe}^{3+}$ to $\mathrm{Fe}^{4+}$ ), but the main electrochemical reaction was insertion of lithium and reduction of $\mathrm{Fe}^{3+}$ to $\mathrm{Fe}^{2+}$.

Other electroactive phosphorus-containing compounds include iron(III) hydroxyl phosphates with lipscombite or tavorite structures [139], $\beta$ - and $\varepsilon$ VOPO $_{4}$ [140], and $\mathrm{LiVP}_{2} \mathrm{O}_{7}$ [141]. Although the Nasicons, 3D-framework structures, and the aforementioned phosphates and diphosphates all have interesting electrochemical properties, most are not competitive with $\mathrm{LiFePO}_{4}$ or 
the commercialized metal oxides for a variety of reasons. The iron-containing materials generally discharge at too low a voltage for use in Li-ion battery configurations and many have fairly low capacities. Some would need to be lithiated prior to use. The vanadium-containing materials cycle well, and have sufficiently high voltages and capacities to ensure high energy density, but raise concerns about toxicity and environmental impact.

Interest has also recently been directed towards a family of silicates with the general composition $\mathrm{Li}_{2} \mathrm{MSiO}_{4}$, where $\mathrm{M}$ is a divalent cation such as $\mathrm{Fe}^{2+}, \mathrm{Mn}^{2+}$, and $\mathrm{Co}^{2+}$ or a combination of these [142]. The chemical formula implies that it may be possible to extract $2 \mathrm{Li}$ ions per transition metal unit, giving a very high theoretical specific capacity of about $330 \mathrm{mAh} / \mathrm{g}$. These materials adopt structures in which $\mathrm{Li}, \mathrm{Si}$ and the transition metal ions all occupy tetrahedral sites in a distorted close-packed oxygen array. The particular polymorph obtained depends upon the nature of the transition metal as well as temperature and method of preparation. In the $\beta$-polymorphs (low temperature forms), the tetrahedra share only corners, and all point in the same direction. In $\gamma$ polymorphs (high temperature forms), triads of tetrahedra are arranged so that the central one points in the opposite direction and shares edges with the two outer tetrahedra. Numerous tetrahedral structures exist, with different ordering of the ions and varying degrees of distortion. Several different views of an electro-active $\beta$-polymorph (space group $P\left(m n 2_{1}\right.$ ) are shown in Figure 14 , which illustrates its quasi-layered nature. Accurate structure determination of these phases is complicated by the presence of impurities in many preparations and variations in synthetic procedures, which may lead to subtle structural differences [142g, 143]. 

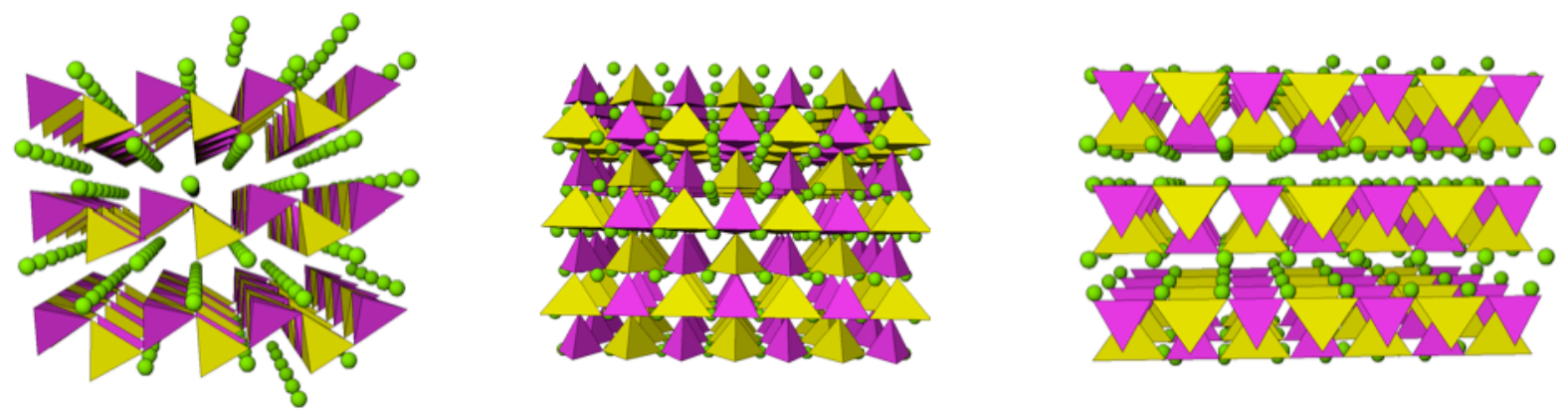

Figure 14. Views of a $\beta$-polymorph of $\mathrm{Li}_{2} \mathrm{MSiO}_{4}$ looking down the a-axis (left), the $b$-axis (middle), and the $c$-axis (right). $\mathrm{MO}_{4}$ (yellow) and $\mathrm{SiO}_{4}$ (pink) tetrahedra alternate and connect to form layers through which lithium ions (green spheres) can diffuse.

About one $\mathrm{Li}^{+}$per formula unit can be extracted from $\mathrm{Li}_{2} \mathrm{FeSiO}_{4}$ in electrochemical cells at low current densities and at $60^{\circ} \mathrm{C}[142 \mathrm{a}, \mathrm{b}]$. The initial extraction takes place at about $3.1 \mathrm{~V}$ vs $\mathrm{Li} / \mathrm{Li}^{+}$, but subsequent discharges and charges occur at $2.8 \mathrm{~V}$. This indicates that a structural change takes place, the exact nature of which is not entirely clear. After this initial change, however, relatively good cycling is observed, with an overall capacity of about $130 \mathrm{mAh} / \mathrm{g}$ (corresponding to somewhat less than $1 \mathrm{Li}^{+}$per $\mathrm{Li}_{2} \mathrm{FeSiO}_{4}$ ). There is no experimental evidence that more than one $\mathrm{Li}^{+}$can be extracted, and first principles calculations indicate that it is not possible to do so at potentials compatible with conventional organic liquid electrolytes [144].

The differences between the potentials at which the first and second lithium ions can be extracted are much smaller when $\mathrm{M}=\mathrm{Mn}$, Co, or $\mathrm{Ni}$ in $\mathrm{Li}_{2} \mathrm{MSiO}_{4}$ than when it is Fe, however. As with the olivine system, the redox potentials for $\mathrm{Li}_{2} \mathrm{MnSiO}_{4}$ electrochemical processes (at least for extraction of the first lithium) 
are expected to be within the oxidative stability limits of organic electrolytes, while those of $\mathrm{Li}_{2} \mathrm{CoSiO}_{4}$ and $\mathrm{Li}_{2} \mathrm{NiSiO}_{4}$ are probably not. However the electrochemical behavior of $\mathrm{Li}_{2} \mathrm{MnSiO}_{4}$ appears to be much worse than that of $\mathrm{Li}_{2} \mathrm{FeSiO}_{4}[142 \mathrm{~b}, \mathrm{~g}]$. Belharaouk et al. [142d] were able to achieve initial discharge capacities of about $135 \mathrm{mAh} / \mathrm{g}$ at room temperature, over a wide voltage range, by using carbon-coated submicron-sized particles, but this is still far less than predicted for complete extraction of all the lithium. Discharge capacities as high as about $250 \mathrm{mAh} / \mathrm{g}$, however, can be obtained when mixed metal compounds $\mathrm{Li}_{2} \mathrm{Mn}_{x} \mathrm{Fe}_{1-\mathrm{x}} \mathrm{SiO}_{4}[142 \mathrm{c}, \mathrm{g}]$ are used as cathodes in lithium cells. Unfortunately, the quality of the energy obtained is poor because the voltage profiles are steeply sloping over a range of about $4.5-1.0 \mathrm{~V}$ vs $\mathrm{Li} / \mathrm{Li}^{+}$. At such low potentials, relatively little power can be obtained from the electrode. The extreme slope may be partly due to the severe kinetic and electronic limitations of the materials, leading to large over-potentials in lithium cells. If so, a combination of the carbon-coating and nano-structuring strategies used to improve the olivines may ameliorate the poor voltage characteristics and lead to new cathodes with nearly double the energy currently available.

\section{Conversion Electrodes}

A different class of electrode materials is based not upon insertion processes but on the displacement reactions of binary metal compounds [145] (equation 4).

$$
n \mathrm{ni}^{+}+n e^{-}+\mathrm{M}^{\mathrm{n}+} \mathrm{X}_{\mathrm{m}} \leftrightarrow \mathrm{M}+\mathrm{nLiX} \mathrm{m} / \mathrm{n} \quad(\mathrm{X}=\mathrm{O}, \mathrm{F}, \mathrm{N}, \mathrm{S})
$$

Conversion electrodes have long been used in primary systems (e.g., Li/CF batteries), but have only been proposed for use in rechargeable devices 
recently, when it was recognized that the reactions could be made reversible for nanoparticulate materials. While the specific capacities can be enormous, the voltage characteristics make most of these electrodes more suitable for use as anodes rather than as cathodes. A notable exception seems to be that of metal fluorides, which are electroactive anywhere from $2-4 \mathrm{~V} v \mathrm{Li} / \mathrm{Li}^{+}$, depending on the identity of the metal, with specific capacities as high as $600 \mathrm{mAh} / \mathrm{g}$. It is typical of conversion electrodes to exhibit significant hysteresis upon recharge, which may be intrinsic to the materials and processes. The mechanisms of conversion reactions are complex and involve bond breaking and considerable rearrangement, unlike that of insertion electrodes. The reassembly of the original phase upon recharge does not necessarily involve the same kinetic pathways and intermediates as the production of the elemental metal and LiF during discharge. Thus, it may not be possible to remove the hysteresis entirely either by engineering of devices or by improving the material properties to ensure faster rate capability. This property has an adverse effect on the roundtrip efficiencies, and may make conversion electrodes unsuitable for $\mathrm{Li}$ ion batteries unless a solution can be found to this problem.

\section{Future Directions}

Because none of the cathode materials discussed above are ideal for every application, the search for new insertion electrodes continues. Batteries are relatively simple devices, but the simultaneous requirements for high energy density, long cycle life, safety, and low cost impose stringent restrictions upon the choices available for cathode materials. The highly successful example of $\mathrm{LiFePO}_{4}$ has directed researchers towards the exploration of other poly-anionic compounds that may share its excellent thermal stability at high states of charge. It is now evident that nano-structuring and/or conductive coatings can 
overcome kinetic and electronic limitations, allowing materials that would once have been thought of as unsuitable for electrodes to be considered. Changes in the phase behavior of nano-particulate materials (in comparison to the conventionally sized powders) can render compounds electro-active that, in bulk form, appear to be unpromising due to their insulating nature. The shortened diffusion distances for lithium in nanoparticles may enable high rate capability in powders that appear to have severe rate limitations when micronsized or larger. While this allows the menu of potential cathodes to be greatly expanded, the concept of "going nano" should be approached with caution. It is most successful when it is applied to materials that undergo redox well within the electrolyte stability range, such as with $\mathrm{LiFePO}_{4}$. The increased surface area of nano-particulate powders compared to conventionally sized materials exacerbates any tendency towards irreversible reaction with electrolytes. In addition to the very serious safety concerns this raises, the paradoxical result may be to lower rate capability due to the increased presence of resistive reaction layers on cathode particle surfaces [146]! Nano-sizing may also adversely impact practical specific energies because processing into electrodes becomes more difficult. It is often necessary, for example, to add more carbon to the composite cathode to ensure good electrical connectivity, but this contributes dead weight. High surface area particles also do not pack well, leading to decreases in the tap densities and lower energy densities. Ensuring that nanoparticles are regularly shaped rather than irregular can ameliorate these tendencies, however [147]. Another potentially useful approach is to synthesize mesoporous materials [148] in which the particles are micron-sized but contain pores of controlled sizes and distributions so as to maximize contact between the electrolyte and active material. This effectively shortens diffusion 
distances, while minimizing the tap density effects and maintaining ease of electrode processing.

The use of nano-metric or very thin coatings on cathode particle surfaces to improve the electronic conductivity of a material, to decrease dissolution, suppress oxygen loss, or to extend the operating voltage range, is somewhat less problematic than simply nano-sizing cathode powders. In principle, this may allow use of a wider variety of materials, including high voltage/high-energy electrodes safely, without compromising cycle life or requiring the use of exotic electrolytes. Here the challenge is to identify and prepare coatings that prevent contact with electrolyte, yet allow transport of lithium ions. They must also remain essentially defect-free over many cycles in which the cathode particles may undergo significant volume changes. A related concept is the preparation of "core-shell" or compositionally graded materials in which two or more compounds are combined in the same particle [149]. The core of the material can be a high-capacity material and the outer shell one that has lower energy but better thermal stability, for example. A difficulty is the tendency for the shell to become detached from the core if the volume changes upon cycling are not carefully matched. A compositionally graded material is less subject to these stresses, but more complex to prepare.

Researchers continue to look for materials that can deliver higher capacities and energies than those currently available. The layered-layered composite materials (i.e., the solid solutions between $\mathrm{Li}_{2} \mathrm{MnO}_{3}$ and $\mathrm{LiNi}_{0.5} \mathrm{Mn}_{0.5} \mathrm{O}_{2}$ or $\mathrm{LiNi}_{x} \mathrm{Co}_{1-2 x} \mathrm{Mn}_{\mathrm{x}} \mathrm{O}_{2}$ ), which are very high capacity once they are activated in electrochemical cells, are a recent promising development. Cathodes that can undergo more than one oxidation state change per metal center reversibly could substantially increase the capacity of lithium-ion batteries. These include the 
$\mathrm{Li}_{2} \mathrm{MSiO}_{4}$ compounds and conversion electrodes discussed above, but these require much more work before they can be envisioned for use in lithium ion batteries.

The challenges presented by these new materials illustrate the delicate balance of performance characteristics, cost, and safety that the battery electrode designer must be able to meet. There is now renewed interest among researchers in lithium metal batteries, because of the very high energy densities that might be achieved. However, now instead of intercalation electrodes, developers are reconsidering the use of sulfur and air (oxygen) cathodes for lithium metal batteries intended for vehicles. The extremely high theoretical capacities of these materials (e.g., over $1600 \mathrm{mAh} / \mathrm{g}$ for sulfur) in lithium batteries are certainly tantalizing, but the difficulties associated with their use have proven daunting. In the case of sulfur, $\mathrm{LiS}_{\mathrm{x}}$ intermediates dissolve in the electrolyte solutions, eventually migrating to the lithium anode and precipitating as $\mathrm{Li}_{2} \mathrm{~S}$. The development of the protected lithium electrode (PLE) by PolyPlus Battery Company (Berkeley, CA) has extended the cycle life significantly, and Li/S batteries are now used for some military applications. In PLEs, the lithium anode is covered by a thin dense protective film (e.g., a lithium ion conducting ceramic such as Lisicon, a lithium ion conducting ceramic with the Nasicon structure), which not only prevents contact with soluble intermediates but also with the electrolyte. An interlayer between the lithium and the protective layer is also needed to prevent reduction of the latter. Thus, in principle, it is possible to operate lithium cells with a wide variety of electrolytes, including aqueous ones. A lithium/water battery has even been developed for niche applications, although it is intended for use only as a primary, at present. 
While in principle it should be possible to operate a lithium/air battery using a PLE to prevent contact of lithium with adventitious water and $\mathrm{CO}_{2}$ in the atmosphere, rechargeable systems have so far eluded success. The reduction of oxygen itself is somewhat sluggish, necessitating the use of a catalyst. The $\mathrm{Li}_{2} \mathrm{O}_{2}$, which is the reaction product when nonaqueous electrolytes are used, precipitates out during discharge and eventually clogs the pores of the air electrode structure. While some researchers have claimed to have successfully recharged a lithium/air battery, the large hysteresis observed suggests that a side-reaction involving the electrolyte is responsible for the charging behavior instead of re-oxidation of $\mathrm{Li}_{2} \mathrm{O}_{2}$ to oxygen.

Ultimately, the success or failure of lithium/sulfur or air systems, however, hinges upon convincing demonstration of safe and reliable operation of the lithium anode over the many cycles required for applications requiring rechargeable devices.

\section{Acknowledgment}

This work was supported by the Assistant Secretary for Energy Efficiency and Renewable Energy, Office of Vehicle Technologies of the U.S. Department of Energy under Contract No. DE-AC02-05CH11231. The author would like to thank Dr. Kinson Kam, Dr. Jordi Cabana, and Mr. Thomas Conry for helpful discussion.

\section{Bibliography}

[1]. a) Whittingham MS, Gamble FR (1975) The Lithium Intercalates of the Transition Metal Dichalcogenides. Mat. Res. Bull. 10: 363-372 b) Whittingham MS (1976) The Role of Ternary Phases in Cathode Reactions. J. Electrochem.

Soc. 123: $315-320$ c) Whittingham MS (1978) Chemistry of Intercalation 
Compounds: Metal Guests in Chalcogenide Hosts. Prog. Solid St. Chem. 12:4199

[2] a) Mizushima K, Jones PC, Wiseman PJ, Goodenough JB (1980) $\mathrm{Li}_{x} \mathrm{CoO}_{2}$ $(0 \leq x \leq 1)$ : A New Cathode Material for Batteries of High Energy Density. Mat. Res. Bull. 15: 783-389 b) Goodenough, JB (2007) Cathode Materials: A Personal Perspective. J. Power Sources 174: 996-1000

[3] Dresselhaus MS, Dresselhaus G (1981) Intercalation Compounds of Graphite. Adv. Phys. 30:139-326

[4] Fong R, von Sacken U, Dahn JR (1990) Studies of Lithium Intercalation into Carbons Using Nonaqueous Electrochemical Cells. J. Electrochem. Soc. 137: $2009-2013$

[5] Nagaura T, Tozawa K (1990) Lithium Ion Rechargeable Battery. Prog. Batteries Solar Cells 9: 209-219

[6] Akridge J, Brodd R (2010) Li-ion Markets. Pacific Power Symposium, Waikoloa, HI

[7] Karden E, Ploumen S, Fricke B, Miller T, Snyder K (2007) Energy Storage Devices for Future Hybrid Electric Vehicles. J. Power Sources 168: 2-11

[8] Chalk SG, Miller JF (2006) Key Challenges and Recent Progress in Batteries, Fuel Cells, and Hydrogen Storage for Clean Energy Systems. J. Power Sources 159: 73-80

[9] Gaines L, Cuenca R (2000) Costs of Lithium-Ion Batteries for Vehicles. Report, Center for Transportation Research, Argonne National Laboratory [10] Murphy DW, Christian PA (1979) Solid State Electrodes for High Energy Batteries. Science 205: 651-656 
[11] a) Ohzuku T, Ueda A (1994) Solid-State Redox Reactions of $\mathrm{LiCoO}_{2}(\mathrm{R}-3 \mathrm{~m})$ for 4 Volt Secondary Lithium Cells. J. Electrochem. Soc. 141:2972-2977 b) Reimers JN, Dahn JR (1992) Electrochemical and In Situ Diffraction Studies of Lithium Intercalation in $\mathrm{Li}_{x} \mathrm{CoO}_{2}$. J. Electrochem. Soc. 139: 2091-2097 [12] Chen Z, Lu Z, Dahn JR (2002) Staging Phase Transitions in $\mathrm{Li}_{x} \mathrm{CoO}_{2}$. J. Electrochem Soc. 149:A1604-A1609

[13] a) Aurbach D, Markovsky B, Rodkin A, Levi E, Cohen YS, Kim H-J, Schmidt M. (2002) On the Capacity Fading of $\mathrm{LiCoO}_{2}$ Intercalation Electrodes: The Effect of Cycling, Storage, Temperature, and Surface Film Forming Additives. Electrochim. Acta 47: 4291-4306 b) Amatucci GG, Tarascon JM, Klein LC (1996) $\mathrm{CoO}_{2}$, The End Member of the $\mathrm{Li}_{x} \mathrm{CoO}_{2}$ Solid Solution. J. Electrochem. Soc. 143: 1114-1123 c) Van der Ven A, Aydinol MK, Ceder G (1998) FirstPrinciples Evidence for Stage Ordering in $\mathrm{Li}_{x} \mathrm{CoO}_{2}$. J. Electrochem. Soc. 145: 2149- 2155 d) Xia H, Lu L, Meng YS, Ceder G (2007) Phase Transitions and High Voltage Electrochemical Behavior of $\mathrm{LiCoO}_{2}$ Thin Films Grown by Pulsed Laser Deposition. J. Electrochem. Soc. 154: A337-A3 42

[14] a) Cho J, Kim G (1999) Enhancement of Thermal Stability of $\mathrm{LiCoO}_{2}$ by $\mathrm{LiMn}_{2} \mathrm{O}_{4}$ Coating. Electrochem. and Solid-State Lett. 2:253-255 b) Kim B, Kim C, Kim T-G, Ahn D, Park B (2006) The Effect of $\mathrm{AlPO}_{4}-$ Coating Layer on the Electrochemical Properties in $\mathrm{LiCoO}_{2}$ Thin Films. J. Electrochem. Soc. 153:A1773-A1777 c) Chen Z, Dahn JR (2004) Methods to Obtain Excellent Capacity Retention in $\mathrm{LiCoO}_{2}$ Cycled to 4.5V. Electrochim. Acta 49: 1079-1090 [15] a) Thomas MGSR, David WIF, Goodenough JB (1985) Synthesis and Structural Characterization of the Normal Spinel $\mathrm{Li}\left[\mathrm{Ni}_{2} \mathrm{O}_{4}\right]$. Mat. Res. Bull. 20:1137-1146 b) Dahn JR, von Sacken U, Michal CA (1990) Structure and 
Electrochemistry of $\mathrm{Li}_{1 \pm y} \mathrm{NiO}_{2}$ and a new $\mathrm{Li}_{2} \mathrm{NiO}_{2}$ phase with the $\mathrm{Ni}(\mathrm{OH})_{2}$ Structure. Sol. State Ionics 44:87-97 c) Broussely M, Perton F, Biensan P, Bodet JM, Labat J, Lecerf A, Delmas C, Rougier A, Pérès (1995) $\mathrm{Li}_{x} \mathrm{NiO}_{2}$, a Promising Cathode for Rechargeable Lithium Batteries. J. Power Sources 54: 109-114 d) Dahn JR, von Sacken U, Juzkow MW, Al-Janaby H (1991) Rechargeable $\mathrm{LiNiO}_{2} /$ Carbon Cells. J. Electrochem. Soc. 138:2207-2211 [16] Rougier A, Gravereau P, Delmas C (1996) Optimization of the Composition of the $\mathrm{Li}_{1-z} \mathrm{Ni}_{1+z} \mathrm{O}_{2}$ Electrode Materials: Structural, Magnetic, and Electrochemical Studies. J. Electrochem. Soc. 143:1168-1175

[17] a) Pérès JP, Delmas C, Rougier A, Broussely $M$, Perton F, Biensan P, Willman P (1996) The Relationship between the Composition of Lithium Nickel Oxide and the Loss of Reversibility during the First Cycle. J. Phys. Chem. Solids 57:1057-1060 b) Delmas C, Pérès JP, Rougier A, Demourgues A, Weill F, Chadwick A, Broussely M, Perton F, Biensan P, Willman P (1997) On the Behavior of the $\mathrm{Li}_{x} \mathrm{NiO}_{2}$ System: An Electrochemical and Structural Overview. J. Power Sources 68: 120-125

[18] Ohzuku T, Ueda A, Nagayama M, Iwakoshi Y, Komori H (1993) Comparative Study of $\mathrm{LiCoO}_{2}, \mathrm{LiNi}_{1 / 2} \mathrm{Co}_{1 / 2} \mathrm{O}_{2}$ and $\mathrm{LiNiO}_{2}$ for 4 Volt Secondary Lithium Cells. Electrochim. Acta 38: 1159-1167

[19] a) Dahn JR, Fuller EW, Obrovac M, von Sacken U (1994) Thermal Stability of $\mathrm{Li}_{x} \mathrm{CoO}_{2}, \mathrm{Li}_{x} \mathrm{NiO}_{2}$ and $\lambda-\mathrm{MnO}_{2}$ and Consequences for the Safety of Li-ion Cells. Sol. State Ionics 69: 265-270 b) Ohzuku T, Ueda A, Kouguchi (1995) Synthesis and Characterization of $\mathrm{LiAl}_{1 / 4} \mathrm{Ni}_{3 / 4} \mathrm{O}_{2}$ (R-3m) for Lithium-lon (Shuttlecock) Batteries. J. Electrochem. Soc. 142: 4033-439 c) Arai H, Sakurai Y (1999) Characteristics of $\mathrm{Li}_{x} \mathrm{NiO}_{2}$ Obtained by Chemical Delithiation. J. Power 
Sources 81-82: 401-405 c) Albrecht S, Kümpers J, Kruft M, Malcus S, Vogler C, Wahl M, Wohlfahrt-Mehrens M (2003) Electrochemical and Thermal Behavior of Aluminum- and Magnesium-doped Spherical Lithium Nickel Cobalt Mixed Oxides $\mathrm{Li}_{1-\mathrm{x}}\left(\mathrm{Ni}_{1-\mathrm{y}-\mathrm{z}} \mathrm{Co}_{y} \mathrm{M}_{\mathrm{z}}\right) \mathrm{O}_{2}(\mathrm{M}=\mathrm{Al}, \mathrm{Mg})$. J. Power Sources 119-121: 178-183 [20] Onnerud PT, Shi JJ, Dalton SL, Lampe-Onnerud C (2008) Lithium Metal Oxide Materials and Methods of Synthesis and Use. US Patent 2008/0286460 A1

[21] a) Chen CH, Liu J, Stoll ME, Henriksen G, Vissers DR, Amine K. (2004) Aluminum-doped Lithium Nickel Cobalt Oxide Electrodes for High-Power Lithium-Ion Batteries. J. Power Sources 128:278-285. b) Kostecki R, Lei J, McLarnon F, Shim J, Striebel K (2006) Diagnostic Evaluation of Detrimental Phenomena in High-Power Lithium-Ion Batteries. J. Electrochem. Soc. 153:A669-A672

[22] Tabuchi M, Tsutsui S, Masquelier C, Kanno R, Ado K, Matsubara I, Nasu S, Kageyama H (1998) Effect of Cation Arrangement on the Magnetic Properties of Lithium Ferrites $\left(\mathrm{LiFeO}_{2}\right.$ Prepared by Hydrothermal Reaction and Postannealing Method. J. Solid State Chem. 140: 159-167

[23] Ado K, Tabuchi M, Kobayashi H, Kageyama H, Nakamura O, Inaba Y, Kanno R (1997) Preparation of $\mathrm{LiFeO}_{2}$ with Alpha-NaFeO - -Type Structure Using a Mixed-Alkaline Hydrothermal Method. J. Electrochem. Soc. 144: L177-L180 [24] a) Kanno R, Shirane T, Kawamoto Y, Takeda Y, Takano M, Ohashi M, Yamaguchi Y (1996) Synthesis, Structure, and Electrochemical Properties of a New Lithium Iron Oxide, $\mathrm{LiFeO}_{2}$, with a Corrugated Layer Structure. J. Electrochem. Soc. 143: 2435-2442 b) Morales J, Santos-Peña J (2007) Highly Electroactive Nanosized $\alpha-\mathrm{LiFeO}_{2}$. Electrochem. Commun. 9:2116-2120 
[25] Johnson CS, Kang S-H, Vaughey JT, Pol SV, Balasubramanian M, Thackeray MM (2010) $\mathrm{Li}_{2} \mathrm{O}$ Removal from $\mathrm{Li}_{5} \mathrm{FeO}_{4}$ : A Cathode Precursor for Lithium-Ion Batteries. Chem. Mater. 22: 1263-1270

[26] Armstrong AR, Bruce PG (1996) Synthesis of Layered $\mathrm{LiMnO}_{2}$ as an Electrode for Rechargeable Lithium Batteries. Nature 381:499-500

[27] Thackeray MM (1997) Manganese Oxides for Lithium Batteries. Prog. Solid St. Chem. 25: 1-71

[28] Reed J, Ceder G (2004) Role of Electronic Structure in the Susceptibility of Metastable Transition-Metal Oxide Structures to Transformation. Chem. Rev. 104: $4513-4534$

[29] a) Paulsen JM, Thomas CL, Dahn JR (199) Layered Li-Mn-Oxide with the O2 Structure: A Cathode Material for Li-Ion Cells Which Does Not Convert to Spinel. J. Electrochem. Soc. 146: 3560-3565 b) Eriksson TA, Lee YJ, Hollingsworth J, Reimer JA, Cairns EJ, Zhang X-F, Doeff, MM (2003) Influence of Substitution on the Structure and Electrochemistry of Layered Manganese Oxides. Chem. Mater 15: 4456-4463

[30] a) Dollé M, Patoux S, Doeff MM (2005) Layered Manganese Oxide Intergrowth Electrodes for Rechargeable Lithium Batteries. 1. Substitution with Co or Ni. Chem. Mater. 17: 1036-1043 b) Patoux S, Dollé M, Doeff MM (2005) Layered Manganese Oxide Intergrowth Electrodes for Rechargeable Lithium Batteries. 2. Substitution with Al. Chem Mater. 17: 1044-1054 [31] Robertson AD, Armstrong AR, Bruce PG (2000) Influence of Ion Exchange Conditions on the Defect Chemistry and Performance of Cobalt Doped Layered Lithium Manganese Oxide Based Intercalation Compounds. Chem. Commun. 1997-1998 
[32] a) Doeff MM, Peng MY, Ma Y, De Jonghe LC (1994) Orthorhombic $\mathrm{Na}_{x} \mathrm{MnO}_{2}$ as a Cathode Material for Secondary Sodium and Lithium Polymer Batteries. J. Electrochem. Soc. 141: L145-L147 b) Doeff MM, Richardson TJ, Kepley L (1996) Lithium Insertion Processes of Orthorhombic $\mathrm{Na}_{x} \mathrm{MnO}_{2}$-Base Electrode Materials. J. Electrochem. Soc. 143: 2507-2516 c) Hu F, Doeff MM (2004) Electrochemical Characterization of Manganese Oxide Cathode Materials Based on $\mathrm{Na}_{0.4} \mathrm{MnO}_{2}$. J. Power Sources 129: 296-302

[33] Armstrong AR, Huang $H$, Jennings RA, Bruce PG (1998) $\mathrm{Li}_{0.44} \mathrm{MnO}_{2}$ : an Intercalation Electrode with a Tunnel Structure and Excellent Cyclability. J. Mater. Chem. 8:255-259

[34] Doeff MM, Anapolsky A, Edman L, Richardson TJ, De Jonghe LC (2001) A High-Rate Manganese Oxide for Rechargeable Lithium Battery Applications. J. Electrochem. Soc. 148:A230-A236

[35] Akimoto J, Awaka J, Takahashi Y, Kijima N, Tabuchi M, Nakashima A, Sakaebe H, Tatsumi K (2005) Synthesis and Electrochemical Properties of $\mathrm{Li}_{0.44} \mathrm{MnO}_{2}$ as a Novel 4V Cathode Material. Electrochem. and Solid-State Lett. 8: A554-A557

[36] Kalyani P, Chitra S, Mohan T, Gopukumar S (1999) Lithium Metal Rechargeable Cells Using $\mathrm{Li}_{2} \mathrm{MnO} 3$ as the Positive Electrode. J. Power Sources 80:103-106

[37] Yu DYW, Yanagida K, Kato Y, Nakamura H (2009) Electrochemical Activities in $\mathrm{Li}_{2} \mathrm{MnO}_{3}$. J. Electrochem. Soc. 156: A417-A424

[38] Rossouw MH, Thackeray MM (1991) Lithium Manganese Oxides from $\mathrm{Li}_{2} \mathrm{MnO}_{3}$ for Rechargeable Lithium Battery Applications. Mat. Res. Bull. 26: 463473 
[39] Paik Y, Grey CP, Johnson CS, Kim J-S, Thackeray MM (2002) Lithium and Deuterium NMR Studies of Acid-Leached Layered Lithium Manganese Oxides. Chem. Mater. 14:5109-5115

[40] Storey C, Kargina I, Grincourt Y, Davidson IJ, Yoo YC, Seung DY (2001) Electrochemical Characterization of a New High Capacity Cathode. J. Power Sources 97-98: 541-544

[41] Ammundsen B, Paulsen J, Davidson I, Liu R-S, Shen C-H, Chen J-M, Jang L-Y, Lee J-F (2002) Local Structure and First Cycle Redox Mechanism of Layered $\mathrm{Li}_{1.2} \mathrm{Cr}_{0.4} \mathrm{Mn}_{0.4} \mathrm{O}_{2}$ Cathode Material. J. Electrochem. Soc. 149: A431A436

[42] a) Ohzuku T, Makimura Y (2001) Layered Lithium Insertion Material of $\mathrm{LiNi}_{1 / 2} \mathrm{Mn}_{1 / 2} \mathrm{O}_{2}$ : A Possible Alternative to $\mathrm{LiCoO}_{2}$ for Advanced Lithium-lon Batteries. Chem. Lett. 744-745. b) Rossen E, Jones CDW, Dahn JR (1992) Structure and Electrochemistry of $\mathrm{Li}_{x} \mathrm{Mn}_{y} \mathrm{Ni}_{1-y} \mathrm{O}_{2}$. Solid State Ionics 57: 311-318 c) Makimura Y, Ohzuku T (2003) Lithium Insertion Material of $\mathrm{LiNi}_{1 / 2} \mathrm{Mn}_{1 / 2} \mathrm{O}_{2}$ for Advanced Lithium-Ion Batteries. J. Power Sources 119-121: 156-160

[43] Lu Z, MacNeil DD, Dahn JR (2001) Layered Cathode Materials Li[Nix $\mathrm{Li}_{(1 / 3-}$ $\left.{ }_{2 \mathrm{x} / 3)} \mathrm{Mn}_{(2 / 3-\mathrm{x} / 3)}\right] \mathrm{O}_{2}$ for Lithium-Ion Batteries. Electrochem. and Solid-State Lett. 4: A191-A194

[44] Reed J, Ceder G (2002) Charge, Potential, and Phase Stability of Layered $\mathrm{Li}\left(\mathrm{Ni}_{0.5} \mathrm{Mn}_{0.5}\right) \mathrm{O}_{2}$. Electrochem. and Solid-State Lett. 5:A145-A148

[45] Yoon W-S, Grey CP, Balasubramanian M, Yang X-Q, McBreen J (2003) In Situ X-ray Absorption Spectroscopic Study on $\mathrm{LiNi}_{0.5} \mathrm{Mn}_{0.5} \mathrm{O}_{2}$ Cathode Material During Electrochemical Cycling. Chem. Mater. 15: 3161-3169 
[46] a) Van der Ven A, Ceder G (2004) Ordering in $\mathrm{Li}_{x}\left(\mathrm{Ni}_{0.5} \mathrm{Mn}_{0.5}\right) \mathrm{O}_{2}$ and its Relation to Charge Capacity and Electrochemical Behavior in Rechargeable Lithium Batteries. Electrochem. Commun. 6:1045-1050 b) Yoon W-S, Paik Y, Yang X-Q, Balasubramanian M, McBreen J, Grey CP (2002) Investigation of the Local Structure of the $\mathrm{LiNi}_{0.5} \mathrm{Mn}_{0.5} \mathrm{O}_{2}$ Cathode Material during Electrochemical Cycling by X-Ray Absorption and NMR Spectroscopy. Electrochem. and Solid State Lett. 5:A263-A266

[47] Lu Z, Beaulieu LY, Donaberger RA, Thomas CL, Dahn JR (2002) Synthesis, Structure, and Electrochemical Behavior of $\mathrm{Li}\left[\mathrm{Ni}_{x} \mathrm{Li}_{1 / 3-2 x / 3} \mathrm{Mn}_{2 / 3-x / 3}\right] \mathrm{O}_{2}$. J. Electrochem. Soc. 149: A778-A791

[48] Kang S-H, Park S-H, Johnson CS, Amine K (2007) Effects of Li Content on Structure and Electrochemical Properties of $\mathrm{Li}_{1+\mathrm{x}}\left(\mathrm{Ni}_{0.5} \mathrm{Mn}_{0.5}\right)_{1-\mathrm{x}} \mathrm{O}_{2} \quad(0 \leq \mathrm{x} \leq 0.15)$ Electrodes in Lithium Cells (1.0-4.8V). J. Electrochem. Soc. 154:A268-A274 [49] Kang K, Meng Y S, Bréger J, Grey CP, Ceder G (2006) Electrodes with High Power and High Capacity for Rechargeable Lithium Batteries. Science 311: $977-980$

[50] Yabuuchi N, Ohzuku T (2003) Novel Lithium Insertion Material of $\mathrm{LiCo}_{1 / 3} \mathrm{Ni}_{1 / 3} \mathrm{Mn}_{1 / 3} \mathrm{O}_{2}$ for Advanced Lithium-Ion Batteries. J. Power Sources 119121: $171-174$

[51] Koyama Y, Tanaka I, Adachi H, Makimura Y, Ohzuku T (2003) Crystal and Electronic Structures of Superstructural $\mathrm{Li}_{1-\mathrm{x}}\left[\mathrm{Co}_{1 / 3} \mathrm{Ni}_{1 / 3} \mathrm{Mn}_{1 / 3}\right] \mathrm{O}_{2} \quad(0 \leq x \leq 1) . \mathrm{J}$. Power Sources 119-121: 644-648

[52] Hwang BJ, Tsai YW, Carlier D, Ceder G (2003) A Combined Computational/Experimental Study on $\mathrm{LiNi}_{1 / 3} \mathrm{Co}_{1 / 3} \mathrm{Mn}_{1 / 3} \mathrm{O}_{2}$. Chem. Mater. $15: 3676-3682$ 
[53] a) Kim J-M, Chung H-T (2003) The First Cycle Characteristics of $\mathrm{Li}\left[\mathrm{Ni}_{1 / 3} \mathrm{Co}_{1 / 3} \mathrm{Mn}_{1 / 3}\right] \mathrm{O}_{2}$. Electrochim. Acta 49:937-944 b) Kobayashi $\mathrm{H}$, Arachi $\mathrm{Y}$, Emura S, Kageyama H, Tatsumi K, Kamiyama T (2005) Investigation on Lithium De-Intercalation Mechanism for $\mathrm{Li}_{1-y} \mathrm{Ni}_{1 / 3} \mathrm{Mn}_{1 / 3} \mathrm{Co}_{1 / 3} \mathrm{O}_{2}$. J. Power Sources 146: 640-644 c) Tsai YW, Hwang BJ, Ceder G, Sheu HS, Liu DG, Lee JF (2005) InSitu X-ray Absorption Spectroscopic Study on Variation of Electronic Transitions and Local Structure of $\mathrm{LiNi}_{1 / 3} \mathrm{Co}_{1 / 3} \mathrm{Mn}_{1 / 3} \mathrm{O}_{2}$ Cathode Material during Electrochemical Cycling. Chem. Mater. 17:3193-3199 d) Kim MG, Shin HJ, Kim J-H, Park S-H, Sun Y-K (2005) XAS Investigation of Inhomogeneous MetalOxygen Bond Covalency in Bulk and Surface for Charge Compensation in Li-lon Battery Cathode $\mathrm{Li}\left[\mathrm{Ni}_{1 / 3} \mathrm{Co}_{1 / 3} \mathrm{Mn}_{1 / 3}\right] \mathrm{O}_{2}$ Material. J.Electrochem. Soc. 152:A1320A1328 e) Yoon W-S, Balasubramanian M, Chung KY, Yang X-Q, McBreen J, Grey CP, Fischer DA (2005) Electrochemical Li-ion Deintercalated Li 1- $_{-}$ ${ }_{x} \mathrm{Co}_{1 / 3} \mathrm{Ni}_{1 / 3} \mathrm{Mn}_{1 / 3} \mathrm{O}_{2}$ Electrode System by Combination of Soft and Hard X-ray Absorption Spectroscopy. J. Am Chem. Soc. 127: 17479-17487

[54] a) Choi J, Manthiram A (2005) Role of Chemical and Structural Stabilities on the Electrochemical Properties of Layered $\mathrm{LiNi}_{1 / 3} \mathrm{Mn}_{1 / 3} \mathrm{Co}_{1 / 3} \mathrm{O}_{2}$ Cathodes. J. Electrochem. Soc. 152:A1714-A1718 b) Belharouak I, Lu W, Vissers D, Amine $\mathrm{K}$ (2006) Safety Characteristics of $\mathrm{Li}\left(\mathrm{Ni}_{0.8} \mathrm{Co}_{0.15} \mathrm{Al}_{0.05}\right) \mathrm{O}_{2}$ and $\mathrm{Li}\left(\mathrm{Ni}_{1 / 3} \mathrm{Co}_{1 / 3} \mathrm{Mn}_{1 / 3}\right) \mathrm{O}_{2}$. Electrochem. Commun. 8:329-335

[55] a) Ngala JK, Chernova NA, Ma M, Mamak M, Zavalij PY, Whittingham MS (2004) The Synthesis, Characterization and Electrochemical Behavior of the Layered $\mathrm{LiNi}_{0.4} \mathrm{Mn}_{0.4} \mathrm{Co}_{0.2} \mathrm{O}_{2}$ Compound. J. Mater. Chem. 14:214-220 b) Xiao J, Chernova NA, Whittingham MS (2008) Layered Mixed Transition Metal Oxide Cathodes with Reduced Cobalt Content for Lithium Ion Batteries. Chem. Mater. 
20: 7454-7464 c) Chernova NA, Ma M, Xiao J, Whittingham MS, Breger J, Grey CP (2007) Layered $\mathrm{Li}_{x} \mathrm{Ni}_{y} \mathrm{Mn}_{\mathrm{y}} \mathrm{Co}_{1-2 \mathrm{y}} \mathrm{O}_{2}$ Cathodes for Lithium Ion Batteries: Understanding Local Structure via Magnetic Properties. Chem. Mater. 19:46824693

[56] a) Liu D, Wang Z, Chen L (2006) Comparison of Structure and Electrochemistry of $\mathrm{Al}$ - and Fe-doped $\mathrm{LiNi}_{1 / 3} \mathrm{Co}_{1 / 3} \mathrm{Mn}_{1 / 3} \mathrm{O}_{2}$. Electrochim. Acta 51:4199-4203 b) Hu S-K, Chou T-C, Hwang B-J, Ceder G (2006) Effect of Co Content on Performance of $\mathrm{LiAl}_{1 / 3-x} \mathrm{Co}_{x} \mathrm{Ni}_{1 / 3} \mathrm{Mn}_{1 / 3} \mathrm{O}_{2}$. J. Power Sources $160: 1287-1293$

[57] Zhou F, Zhao X, Lu Z, Jiang J, Dahn JR (2008) The Effect of Al Substitution on the Reactivity of Delithiated $\mathrm{LiNi}_{1 / 3} \mathrm{Mn}_{1 / 3} \mathrm{Co}_{(1 / 3-z)} \mathrm{Al}_{z} \mathrm{O}_{2}$ with Non-Aqueous Electrolyte. Electrochem. Commun. 10: 1054-1057

[58] a) Wilcox J, Patoux S, Doeff M (2009) Structure and Electrochemistry of $\mathrm{LiNi}_{1 / 3} \mathrm{Co}_{1 / 3-\mathrm{y}} \mathrm{M}_{\mathrm{y}} \mathrm{Mn}_{1 / 3} \mathrm{O}_{2} \quad(\mathrm{M}=\mathrm{Ti}, \quad \mathrm{Al}, \quad \mathrm{Fe})$ Positive Electrode Materials. J. Electrochem. Soc. 156:A192-A198 b) Wilcox JD, Rodriguez EE, Doeff MM (2009) The Impact of Aluminum and Iron Substitution on the Structure and Electrochemistry of $\mathrm{Li}\left(\mathrm{Ni}_{0.4} \mathrm{Co}_{0.2-y} \mathrm{M}_{\mathrm{y}} \mathrm{Mn}_{0.4}\right) \mathrm{O}_{2}$. J. Electrochem. Soc. 156: A1011A1018

[59] Xiao J, Chernova NA, Whittingham MS (2010) Influence of Manganese Content on the Performance of $\mathrm{LiNi}_{0.9-\mathrm{y}} \mathrm{Mn}_{\mathrm{y}} \mathrm{Co}_{0.1} \mathrm{O}_{2}(0.45 \leq \mathrm{y} \leq 0.60)$ as a Cathode Material for Li-Ion Batteries. Chem. Mater. 22:1180-1185

[60] a) Thackeray MM, Kang S-H, Johnson CS, Vaughey JT, Benedek R, Hackney SA (2007) $\mathrm{Li}_{2} \mathrm{MnO}_{3}$-stabilized $\mathrm{LiMO}_{2}(\mathrm{M}=\mathrm{Mn}$, Ni,Co) Electrodes for Lithium-Ion Batteries. J. Mater. Chem. 17:3112-2135 b) Johnson CS, Li N, Lifief C, Thackeray MM (2007) Anomalous Capacity and Cycling Stability of 
$\mathrm{xLi}_{2} \mathrm{MnO}_{3} \cdot(1-\mathrm{x}) \mathrm{LiMO}_{2}$ Electrodes (M=Mn, Ni, Co) in Lithium Batteries at $50^{\circ} \mathrm{C}$. Electrochem. Commun. 9:787-795

[61] Hunter JC (1981) Preparation of a New Crystal Form of Manganese Dioxide: $\lambda-\mathrm{MnO}_{2}$. J. Sol. State Chem. 32:142-147

[62] a) Thackeray MM, David WIF, Bruce PG, Goodenough JB (1983) Lithium Insertion into Manganese Spinels. Mater. Res. Bull. 18:461-472 b) Goodenough JB, Thackeray MM, David WIF, Bruce PG (1984) Lithium Insertion/Extraction Reactions with Manganese Oxides. Rev. Chim. Miner. 21:435-455 [63] Thackeray MM (1999) Spinel Electrodes for Lithium Batteries. J. Am.

Ceram. Soc. 82: 337-3354

[64] a) Tarascon JM, Wang E, Shokoohi FK, McKinnon WR, Colson S (1991) The Spinel Phase of $\mathrm{LiMn}_{2} \mathrm{O}_{4}$ as a Cathode in Secondary Lithium Cells. J. Electrochem. Soc. 138:2859-2864 b) Tarascon JM, McKinnon WR, Coowar F, Bowmer TN, Amatucci G, Guyomard D (1994) Synthesis Conditions and Oxygen Stoichiometry Effects on $\mathrm{Li}$ Insertion into the Spinel $\mathrm{LiMn}_{2} \mathrm{O}_{4} . \mathrm{J}$. Electrochem. Soc. 141: 1421-1431 c) Guyomard D, Tarascon JM (1994) The Carbon/Li $\mathrm{L}_{1+\mathrm{x}} \mathrm{Mn}_{2} \mathrm{O}_{4}$ System. Sol. State lonics 69: 222-237

[65] Xia Y, Zhou Y, Yoshio, M (1997) Capacity Fading on Cycling of 4V Li/LiMn ${ }_{2} \mathrm{O}_{4}$ Cells. J. Electrochem. Soc. 144: 2593- 2600

[66] a) Amatucci G, Tarascon J-M (2002) Optimization of Insertion Compounds such as $\mathrm{LiMn}_{2} \mathrm{O}_{4}$ for Li-lon Batteries. J. Electrochem. Soc. 149:K31-K46

[67] a) Gummow RJ, de Kock A, Thackeray MM (1994) Improved Capacity Retention in Rechargeable 4V Lithium/Lithium Manganese Oxide (Spinel) Cells. Sol. State Ionics 69: 59-67 b) Shaju KM, Subba Rao GV, Chowdari BVR (2002) Spinel Phases, $\mathrm{LiM}_{1 / 6} \mathrm{Mn}_{11 / 6} \mathrm{O}_{4}(\mathrm{M}=\mathrm{Co}$, CoAl, CoCr, CrAl), as Cathodes for 
Lithium-Ion Batteries. Sol. State Ionics 148:343-350 c) Tucker MC, Reimer JA, Cairns EJ (2002) A ${ }^{7}$ Li NMR Study of Capacity Fade in Metal-Substituted Lithium Manganese Oxide Spinels. J. Electrochem. Soc. 149:A574-A585 d) Grush MM, Horne CR, Perera RCC, Ederer DL, Cramer SP, Cairns EJ, Callcott TA (2000) Correlating Electronic Structure with Cycling Performance of Substituted $\mathrm{LiMn}_{2} \mathrm{O}_{4}$ Electrode Materials: A Study Using the Techniques of Soft X-ray Absorption and Emission. Chem. Mater. 12:659-664 e) Myung S-T, Komaba S, Kumagai N (2001) Enhanced Structural Stability and Cyclability of Al-Doped $\mathrm{LiMn}_{2} \mathrm{O}_{4}$ Spinel Synthesized by the Emulsion Drying Method. J. Electrochem. Soc. 148: A482-A489 f) Ariyoshi K, Iwata E, Kuniyoshi M, Wakabayashi H, Ohzuku T (2006) Lithium Aluminum Manganese Oxide Having Spinel Framework Structure for Long-Life Lithium-Ion Batteries. Electrochem. and Sol. State Lett. 9:A557-A560 g) Amatucci GG, Pereira N, Zheng T, Tarascon J-M (2001) Failure Mechanism and Improvement of the Elevated Temperature Cycling of $\mathrm{LiMn}_{2} \mathrm{O}_{4}$ Compounds Through the Use of the $\mathrm{LiAl}_{x} \mathrm{Mn}_{2-}$ ${ }_{\mathrm{x}} \mathrm{O}_{4-\mathrm{z}} \mathrm{F}_{\mathrm{z}}$ Solid Solution. J. Electrochem. Soc. 148:A171-A182

[68] Whittingham MS (2004) Lithium Batteries and Cathode Materials. Chem. Rev. 104:4271-4301

[69] a) Thackeray MM, de Kock A, Rossouw MH, Liles D, Bittihn R, Hoge D (1992) Spinel Electrodes from the Li-Mn-O System for Rechargeable Lithium Battery Applications. J. Electrochem. Soc. 139: 363-366 b) Kim J, Manthiram A (1998) Low Temperature Synthesis and Electrode Properties of $\mathrm{Li}_{4} \mathrm{Mn}_{5} \mathrm{O}_{12} .145$ : L53-L55

[70] a) Du Pasquier, Blyr A, Courjal P, Larcher D, Amatucci G, Gérand B, Tarascon J-M (1999) Mechanism for Limited $55^{\circ} \mathrm{C}$ Storage Performance of 
$\mathrm{Li}_{1.05} \mathrm{Mn}_{1.95} \mathrm{O}_{4}$ Electrodes. J.Electrochem. Soc. 146:428-436 b) Wen SJ, Richardson TJ, Ma L, Striebel KA, Ross PN, Cairns EJ (1996) FTIR Spectroscopy of Metal Oxide Insertion Electrodes. J. Electrochem. Soc. 143:L136-L138 c) Eriksson T, Gustafsson T, Thomas JO (2002) Surface Structure of $\mathrm{LiMn}_{2} \mathrm{O}_{4}$ Electrodes. Electrochem. and Sol. State Lett. 5:A35-A38 d) Akimoto J, Takahashi Y, Kijima N (2005) Direct Observation of the Bulk Degradation of $\mathrm{Li}_{1.1} \mathrm{Mn}_{1.9} \mathrm{O}_{4}$ Single Crystals after High-Temperature Storage. Electrochem. and Sol. State Lett. 8:A361-A364 e) Kobayashi H, Sakaebe H, Komoto K, Kageyama H, Tabuchi M, Tatsumi K, Kohigashi T, Yonemura M, Kanno R, Kamiyama T (2003) Structure and Physical Property Changes of DeLithiated Spinels for $\mathrm{Li}_{1.02-x} \mathrm{Mn}_{1.98} \mathrm{O}_{4}$ After High-Temperature Storage. Sol. State Ionics 156:309-318 f) Quinlan FT, Sano K, Willey T, Vidu R, Tasaki K, Stroeve P (2001) Surface Characterization of the Spinel $\mathrm{Li}_{x} \mathrm{Mn}_{2} \mathrm{O}_{4}$ Cathode Before and After Storage at Elevated Temperatures. Chem. Mater. 13: 4207-4212 [71] a) Tsunekawa H, Tanimoto S, Marubayashi R, Fujita M, Kifune K, Sano M (2002) J. Capacity Fading of Graphite Electrodes Due to the Deposition of Manganese lons on Them in Li-lon Batteries. J. Electrochem. Soc. 149:A1326A1331 b) Amine K, Liu J, Kang S, Belharouak I, Hyung Y, Vissers D, Henriksen G (2004) Improved Lithium Manganese Oxide Spinel/Graphite Li-lon Cells for High-Power Applications. J. Power Sources 129: 14-19

[72] a) Cho J, Kim GB, Lim HS, Kim C-S, Yoo S-I (1999) Improvement of Structural Stability of $\mathrm{LiMn}_{2} \mathrm{O}_{4}$ Cathode Material on $55^{\circ} \mathrm{C}$ Cycling by Sol-Gel Coating of $\mathrm{LiCoO}_{2}$. Electrochem. and Sol. State Lett. 2: 607-609 b) Wang EI (1998) Method of Treating Lithium Manganese Oxide Spinel. US Patent $5,783,328$ 
[73] a) Xu W, Angell CA (2001) LiBOB and Its Derivatives Weakly Coordinating Anions, and the Exceptional Conductivity of Their Nonaqueous Solutions. Electrochem. and Sol. State Lett. 4: E1-E4 b) Xu K, Zhang S, Jow TR, Xu W, Angell CA (2002) LiBOB as Salt for Lithium-Ion Batteries A Possible Solution for High Temperature Operation. c) Chen Z, Amine K (2006) Capacity Fade of $\mathrm{Li}_{1+x} \mathrm{Mn}_{2-\mathrm{x}} \mathrm{O}_{4}$-Based Lithium-Ion Cells. J. Electrochem. Soc. 153: A316-A320

[74] Kitao H, Fujihara T, Takeda K, Nakanishi N, Nohma T (2005) HighTemperature Storage Performance of Li-lon Batteries Using a Mixture of Li-Mn Spinel and Li-Ni-Co-Mn Oxide as a Positive Electrode Material. Electrochem. and Sol. State Lett. 8: A87-A90

[75] MacNeil DD, Dahn JR (2001) The Reaction of Charged Cathodes with Nonaqueous Solvents and Electrolytes II. $\mathrm{LiMn}_{2} \mathrm{O}_{4}$ Charged to 4.2V. J. Electrochem. Soc. 148: A1211-A1215

[76] Thackeray MM (1995) Structural Considerations of Layered and Spinel Lithiated Oxides for Lithium Ion Batteries. J. Electrochem. Soc. 142:2558-2563

[77] a) Sigala C, Guyomard D, Verbaere A, Piffard Y, Tournoux M (1995) Positive Electrode Materials with High Operating Voltage for Lithium Batteries: $\mathrm{LiCr}_{y} \mathrm{Mn}_{2-\mathrm{y}} \mathrm{O}_{4}(0 \leq \mathrm{y} \leq 1)$ Sol. State Ionics 81:167-170 b) Kawai H, Nagata M, Tabuchi M, Tukamoto H, West AR (1998) Novel 5V Spinel Cathode $\mathrm{Li}_{2} \mathrm{FeMn}_{3} \mathrm{O}_{8}$ for Lithium Ion Batteries. Chem. Mater. 10: 3266-3268 c) Ein-Eli Y, Howard WF (1997) $\mathrm{LiCu}_{x}{ }_{x} \mathrm{Cu}^{\mathrm{III}}{ }_{\mathrm{y}} \mathrm{Mn}^{\mathrm{III},}{ }_{[2-(\mathrm{x}+\mathrm{y})]} \mathrm{O}_{4}: 5 \mathrm{~V}$ Cathode Materials. J. Electrochem. Soc. 144: L205-L207 d) Kawai H, Nagata M, Tukamoto H, West AR (1998) A Novel Cathode $\mathrm{Li}_{2} \mathrm{CoMn}_{3} \mathrm{O}_{8}$ for Lithium Ion Batteries Operating Over 5V. J. Mater. Chem. 8:837-839 e) Zhong Q, Bonakdarpour A, Zhang M, Gao Y, Dahn JR 
(1997) Synthesis and Electrochemistry of $\mathrm{LiNi}_{x} \mathrm{Mn}_{2-\mathrm{x}} \mathrm{O}_{4}$. J. Electrochem. Soc. 144: $205-213$

[78] Ohzuku T, Takeda S, Iwanaga M (1999) Solid-State Redox Potentials for $\mathrm{Li}\left[\mathrm{Me}_{1 / 2} \mathrm{Mn}_{3 / 2}\right] \mathrm{O}_{4}$ (Me: 3d-Transition Metal) Having Spinel-Framework Structures: A Series of 5 Volt Materials for Advanced Lithium-Ion Batteries. J. Power Sources 81-82:90-94

[79] a) Sun Y-K, Lee Y-S, Yoshio M, Amine K (2002) Synthesis and Electrochemical Properties of $\mathrm{ZnO}-$ Coated $\mathrm{LiNi}_{0.5} \mathrm{Mn}_{1.5} \mathrm{O}_{4}$ Spinel as $5 \mathrm{~V}$ Cathode Material for Lithium Secondary Batteries. Electrochem. and Sol. State Lett. 5: A99-A102 b) Liu J, Manthiram A (2009) Kinetics Study of the 5V Spinel Cathode $\mathrm{LiMn}_{1.5} \mathrm{Ni}_{0.5} \mathrm{O}_{4}$ Before and After Surface Modifications. J. Electrochem. Soc. 156: A833-A838 c) Patoux S, Daniel L, Bourbon C, Lignier H, Pagano C, Le Cras F, Jouanneau S, Martinet S (2009) High Voltage Spinel Oxides for Li-ion Batteries: From the Materials Research to the Application. J. Power Sources 189: 344-352 [80] a) Kim J-H, Myung S-T, Yoon CS, Oh I-H, Sun Y-K (2004) Effect of Ti Substitution of $\mathrm{LiNi}_{0.5} \mathrm{Mn}_{1.5-\mathrm{x}} \mathrm{Ti}_{\mathrm{x}} \mathrm{O}_{4}$ and Their Electrochemical Properties as Lithium Insertion Material. J. Electrochem. Soc. 151:A1911-A1918 b) Arunkumar TA, Manthiram A (2005) Influence of Lattice Parameter Differences on the Electrochemical Performance of the $5 \mathrm{~V}$ Spinel $\mathrm{LiMn}_{1.5-\mathrm{y}} \mathrm{Ni}_{0.5-\mathrm{z}} \mathrm{M}_{\mathrm{y}+\mathrm{z}} \mathrm{O}_{4}$ (M=Li, Mg, Fe, Co, and Zn). Electrochem. and Sol. State Lett. 8: A403-A405 c) Ooms FGB, Kelder EM, Schoonman J, Wagemaker M, Mulder FM (2002) HighVoltage $\mathrm{LiMg}_{\delta} \mathrm{Ni}_{0.5-\delta} \mathrm{Mn}_{1.5} \mathrm{O}_{4}$ Spinels for Li-ion Batteries. (2002) Sol. State lonics 152-153: $143-153$ 
[81] Gryffoy D, Vandenberghe RE, Legrand E (1991) A Neutron Diffraction Study of Some Spinel Compounds Containing Octahedral Ni and Mn at a 1:3 Ratio. Mater. Sci. Forum 79-82:785-790

[82] a) Takahashi K, Saitoh M, Sano M, Fujita M, Kifune K (2004) Electrochemical and Structural Properties of a $4.7 \mathrm{~V}$-Class $\mathrm{LiNi}_{0.5} \mathrm{Mn}_{1.5} \mathrm{O}_{4}$ Positive Electrode Material Prepared with a Self-Reaction Method. J. Electrochem. Soc. 151:A173-A177 b) Kunduraci M, Amatucci GG (2006) Synthesis and Characterization of Nanostructured 4.7V $\mathrm{Li}_{x} \mathrm{Mn}_{1.5} \mathrm{Ni}_{0.5} \mathrm{O}_{4}$ Spinels for High-Power Lithium-Ion Batteries. J. Electrochem. Soc. 153: A1345-A1352 [83] Wu HM, Belharouak I, Deng H, Abouimrane A, Sun Y-K, Amine K (2009) Development of $\mathrm{LiNi}_{0.5} \mathrm{Mn}_{1.5} \mathrm{O}_{4} / \mathrm{Li}_{4} \mathrm{Ti}_{5} \mathrm{O}_{12}$ System with Long Cycle Life. J. Electrochem. Soc. 156:A1047-A1050

[84] Padhi AK, Nanjundaswamy KS, Goodenough JB (1997) Phospho-olivines as Positive-Electrode Materials for Rechargeable Lithium Batteries. J. Electrochem. Soc. 144:1188-1194

[85] Andersson AS, Kalska B, Häggstrom L, Thomas JO (2000) Lithium Extraction/Insertion in $\mathrm{LiFePO}_{4}$ : An X-ray Diffraction and Mössbauer Spectroscopy Study. Sol. State Ionics 130:41-52

[86] Tarascon, J-M, Armand M (2001) Issues and Challenges Facing Rechargeable Lithium Batteries. Nature 414: 359-376

[87] Ravet N, Chouinard Y, Magnan JF, Besner S, Gauthier M, Armand M (2001) Electroactivity of Natural and Synthetic Triphylite. J. Power Sources 9798: $503-507$ 
[88] Barker J, Saidi MY, Swoyer JL (2003) A Carbothermal Reduction Method for the Preparation of Electroactive Materials for Lithium Ion Applications. J. Electrochem. Soc. 150: A684-A688

[89] Doeff MM, Wilcox JD, Kostecki R, Lau G (2006) Optimization of Carbon Coatings on $\mathrm{LiFePO}_{4}$. J. Power Sources 163: 180-184

[90] a) Dominko R, Bele M. Gaberscek M, Remskar M, Hanzel D, Pejovnik, S, Jamnik J (2005) Impact of the Carbon Coating Thickness on the Electrochemical Performance of $\mathrm{LiFePO}_{4} / \mathrm{C}$ Composites. J. Electrochem. Soc. 152:A607-A610 b) Huang H, Yin S-C, Nazar LF (2001) Approaching Theoretical Capacity of $\mathrm{LiFePO}_{4}$ at Room Temperature at High Rates. Electrochem. and Sol. State Lett. 4: A170-A172 c) Doeff MM, Hu Y, McLarnon F, Kostecki R (2003) Effect of Surface Carbon Structure on the Electrochemical Performance of $\mathrm{LiFePO}_{4}$. Electrochem. and Sol. State Lett. 6:A207-A209 d) Zaghib K, Shim J, Guerfi A, Charest P, Striebel KA (2005) Effect of Carbon Source as Additives in $\mathrm{LifePO}_{4}$ as Positive Electrode for Li-ion Batteries. Electrochem. and Sol. State Lett. 8: A207-A210

[91] a) Wilcox JD, Doeff MM, Marcinek M, Kostecki R (2007) Factors Influencing the Quality of Carbon Coatings on $\mathrm{LiFePO}_{4}$. J. Electrochem. Soc. 154: A389A395 b) Doeff MM, Wilcox JD, Yu R, Aumentado A, Marcinek M, Kostecki R (2008) Impact of Carbon Structure and Morphology on the Electrochemical Performance of $\mathrm{LiFePO}_{4} / \mathrm{C}$ Composites. J. Sol. State Electrochem. 12:995-1001 92 Chen Z, Dahn JR (2002) Reducing Carbon in $\mathrm{LiFePO}_{4} / \mathrm{C}$ Composite Electrodes to Maximize Specific Energy, Volumetric Energy, and Tap Density. J. Electrochem. Soc. 149:A1184-A1189 
[93] Chung S-Y, Bloking JT, Chiang Y-M (2002) Electronically Conductive Phospho-olivines as Lithium Storage Electrodes. Nat. Mater. 1:123-128 [94] a) Thackeray MM (2002) An Unexpected Conductor. Nat. Mater. 1:81-82 b) Ravet N, Abouimrane A, Armand M (2003) From Our Readers. Nat. Mater. 2: 702-703 c) Herle PS, Ellis B, Coombs N, Nazar LF (2004) Nano-network Electronic Conduction in Iron and Nickel Olivine Phosphates. Nat. Mater. 3:147152 d) Delacourt C, Wurm C, Laffont L, Leriche J-B, Masquelier C (2006) Electrochemical and Electrical Properties of $\mathrm{Nb}$ - and/or C-containing $\mathrm{LiFePO}_{4}$ Composites. Sol. State Ionics 177:333-341 e) Rho Y-H, Nazar LF, Perry L, Ryan D (2007) Surface Chemistry of $\mathrm{LiFePO}_{4}$ Studied by Mössbauer and X-Ray Photoelectron Spectroscopy and Its Effect on Electrochemical Properties. J. Electrochem. Soc. 154:A283-A289

[95] Wagemaker M, Ellis BL, Lützenkirchen-Hecht D, Mulder FM, Nazar LF (2008) Proof of Supervalent Doping in Olivine LiFePO 4 . Chem. Mater. 20:63136315

[96] Islam MS, Driscoll DJ, Fisher CAJ, Slater PR (2005) Atomic-Scale Investigation of Defects, Dopants, and Lithium Transport in the LiFePO ${ }_{4}$ OlivineType Battery Material. Chem. Mater. 17:5085-5092

[97] a) Maier J, Amin R (2008) Defect Chemistry of $\mathrm{LiFePO}_{4}$. J. Electrochem. Soc. 155: A339-A344 b) Axmann P, Stinner C, Wohlfahrt-Mehrens M, Mauger A, Gendron G, Julien CM (2009) Nonstoichiometric $\mathrm{LiFePO}_{4}$ : Defects and Related Properties. Chem. Mater. 21:1636-1644 c) Amin R, Maier J (2008) Effect of Annealing on Transport Properties of $\mathrm{LiFePO}_{4}$ : Towards a Defect Chemical Model. Sol. State. Ionics 178:1831-1836 
[98] a) Morgan D, Van der Ven A, Ceder G (2004) Li Conductivity in $\mathrm{Li}_{x} \mathrm{MPO}_{4}$ $(\mathrm{M}=\mathrm{Mn}, \mathrm{Fe}, \mathrm{Co}, \mathrm{Ni})$ Olivine Materials. Electrochem. and Sol. State Lett. 7:A30A32 b) Li J, Yao W, Martin S, Vaknin D (2008) Lithium lon Conductivity in Single Crystal $\mathrm{LiFePO}_{4}$. Sol. State Ionics 179:2016-2019 c) Amin R, Maier J, Balaya P, Chen DP, Lin CT (2008) Ionic and Electronic Transport in Single Crystalline $\mathrm{LiFePO}_{4}$ Grown by Optical Floating Zone Technique. Sol. State Ionics 179:1683-1687

[99] a) Gardiner GR, Islam MS (2010) Anti-Site Defects and Ion Migration in the LiFe ${ }_{0.5} \mathrm{Mn}_{0.5} \mathrm{PO}_{4}$ Mixed-Metal Cathode Material. Chem. Mater. 22:1242-1248 b) Chen J, Vacchio MJ, Wang S, Chernova N, Zavalij PY, Whittingham MS (2008) The Hydrothermal Synthesis and Characterization of Olivines and Related Compounds for Electrochemical Applications. Sol. State Ionics 178:1676-1693 [100] Delacourt C, Poizot P, Levasseur S, Masquelier C (2006) Size Effects on Carbon-Free $\mathrm{LiFePO}_{4}$ Powders The Key to Superior Energy Density.

Electrochem. and Sol. State Lett. 9: A352-A355

[101] a) Meethong N, Huang H-Y S, Carter WC, Chiang Y-M (2007) SizeDependent Lithium Miscibility Gap in Nanoscale $\mathrm{Li}_{1-x} \mathrm{FePO}_{4}$. Electrochem. and Sol. State Lett. 10:A134-A138 b) Gibot P, Casas-Cabanas M, Laffont L, Levasseur S, Carlach P, Hamelet S, Tarascon J-M, Masquelier C (2008) RoomTemperature Single-Phase Li Insertion/Extraction in Nanoscale $\mathrm{Li}_{x} \mathrm{FePO}_{4}$. Nat. Mater. 7:741-747

[102] a) Yamada A, Koizumi H, Sonoyama N, Kanno R (2005) Phase Change in $\mathrm{Li}_{x} \mathrm{FePO}_{4}$. Electrochem. and Sol. State Lett. 8:A409-A413 b) Yamada A, Koizumi H, Nishimura S-I, Sonoyama N, Kanno R, Yonemura M, Nakamura T, 
Kobayashi Y (2006) Room-Temperature Miscibility Gap in $\mathrm{Li}_{x} \mathrm{FePO}_{4}$. Nat. Mater. $5: 357-360$

[103] a) Hamelet S, Gibot P, Casas-Cabanas M, Bonnin D, Grey CP, Cabana J, Leriche J-B, Rodriguez-Carvajal, Courty M, Levasseur S, Carlach P, Van Thournout M, Tarascon J-M, Masquelier C (2009) The Effects of Moderate Thermal Treatments Under Air on $\mathrm{LiFePO}_{4}$-Based Nano Powders. J. Mater. Chem. 19:3979-3991 b) Yu, DYW, Donoue K, Kadohata T, Murata T, Matsuta S, Fujitani S (2008) Impurities in $\mathrm{LiFePO}_{4}$ and Their Influence on Material Characteristics. J. Electrochem. Soc. 155:A526-A530 c) Dokko K, Shiraishi K, Kanamura K (2005) Identification of Surface Impurities on $\mathrm{LiFePO}_{4}$ Particles Prepared by a Hydrothermal Process. (2005) J. Electrochem. Soc. 152: A21992202

[104] a) Delacourt C, Poizot P, Tarascon J-M, Masquelier C (2005) The Existence of a Temperature-Driven Solid Solution in $\mathrm{Li}_{x} \mathrm{FePO}_{4}$ for $0 \leq x \leq 1$. Nat. Mater. 4:254-260 b) Dodd JL, Yazami R, Fultz B (2006) Phase Diagram of $\mathrm{Li}_{x} \mathrm{FePO}_{4}$. Electrochem. and Sol. State Lett. 9:A151-A155

105 Chen G, Song X, Richardson TJ (2007) Metastable Solid-Solution Phases in the $\mathrm{LiFePO}_{4} / \mathrm{FePO}_{4}$ System. J. Electrochem. Soc. 154:A627-A632

[106] Srinivasan V, Newman J (2004) Discharge Model for the Lithium IronPhosphate Electrode. J. Electrochem. Soc. 151:A1517-A1529

[107] Chen G, Song X, Richardson TJ (2006) Electron Microscopy Study of the $\mathrm{LiFePO}_{4}$ to $\mathrm{FePO}_{4}$ Phase Transition. Electrochem. and Sol. State Lett. 9:A295A298

[108] Andersson AS, Thomas JO (2001) The Source of First Cycle Capacity Loss in $\mathrm{LiFePO}_{4}$. J. Power Sources 97-98:498-502 
[109] Laffont L, Delacourt C, Gibot P, Wu MY, Kooyman P, Masquelier C, Tarascon JM (2006) Study of the $\mathrm{LiFePO}_{4} / \mathrm{FePO}_{4}$ Two-Phase System by HighResolution Electron Energy Loss Spectroscopy. Chem. Mater. 18: 5520-5529

[110] Delmas C, Maccario M, Croguennec L, Le Cras F, Weill F (2008) Lithium Deintercalation in $\mathrm{LiFePO}_{4}$ Nanoparticles via a Domino-Cascade Model. Nat. Mater. 7:665-671

[111] Allen JL, Jow TR, Wolfenstine J (2007) Kinetic Study of the Electrochemical $\mathrm{FePO}_{4}$ to $\mathrm{LiFePO}_{4}$ Phase Transition. Chem. Mater. 19:21082111

[112] Lee KT, Kan WH, Nazar LF (2009) Proof of Intercrystallite Ionic Transport in $\mathrm{LiMPO}_{4}$ Electrodes (M=Fe, Mn). J. Am Chem. Soc. 131:6044-6045

[113] Kang B, Ceder G (2009) Battery Materials for Ultrafast Charging and Discharging. Nature 458: 190-193

[114] a) Amine K, Liu J, Belharouak I (2005) High-Temperature Storage and

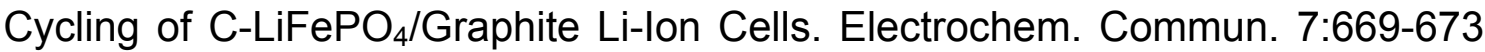

b) Koltypin M, Aurbach D, Nazar L, Ellis B (2007) On the Stability of $\mathrm{LiFePO}_{4}$ Olivine Cathodes under Various Conditions (Electrolyte Solutions, Temperatures). Electrochem. and Solid-State Lett. 10:A40-44

[115] Yang S, Song Y, Zavalij PY, Whittingham MS (2002) Reactivity, Stability and Electrochemical Behavior of Lithium Iron Phosphates. Electrochem. Commun. 4:239-244

[116] Li G, Azuma H, Tohda M (2002) $\mathrm{LiMnPO}_{4}$ as the Cathode for Lithium Batteries. Electrochem. and Sol. State Lett. 5: A135-A137

[117] a) Rissouli K, Benkhouja K, Ramos-Barrado JR, Julien C (2003) Electrochemical Conductivity in Lithium Orthophosphates. Mater. Sci. and Eng. 
B 98:185-189 b) Delacourt C, Laffont L, Bouchet R, Wurm C, Leriche J-B, Morcrette M, Tarascon J-M, Masquelier C (2005) Toward Understanding of Electrical Limitations (Electronic, Ionic) in $\mathrm{LiMPO}_{4}(\mathrm{M}=\mathrm{Fe}, \mathrm{Mn})$ Electrode Materials. J. Electrochem. Soc. 152: A913-A921

[118] a) Delacourt C, Poizot P, Morcrette M, Tarascon J-M, Masquelier C (2004) One Step Low-Temperature Route for the Preparation of Electrochemically Active $\mathrm{LiMnPO}_{4}$ Powders. Chem. Mater. 16: 93-99 b) Yang J and Xu JJ (2006) Synthesis and Characterization of Carbon-Coated Lithium Transition Metal Phosphates $\mathrm{LiMPO}_{4}(\mathrm{M}=\mathrm{Fe}, \mathrm{Mn}, \mathrm{Co}, \mathrm{Ni})$ Prepared via a Nonaqueous Sol-Gel Route. J. Electrochem. Soc. 153: A716-A723 c) Kwon N-H, Drezen T, Exnar I, Teerlinck I, Isono M, and Graetzel M (2006) Enhanced Electrochemical Performance of Mesoparticulate $\mathrm{LiMnPO}_{4}$ for Lithium Ion Batteries. Electrochem. and Solid State Lett. 9, A277-A280 d) Kim TR, Kim DH, Ryu HW, Moon JH, Lee JH, Boo S, Kim J (2007) Synthesis of Lithium Manganese Phosphate Nanoparticle and its Properties. J. Phys. Chem. Sol. 68, 1203-1206

d) Bakenov Z, Taniguchi I (2010) Electrochemical Performance of Nanocomposite $\mathrm{LiMnPO}_{4} / \mathrm{C}$ Cathode Materials for Lithium Batteries. 12:75-78 e) Xiao J, Xu W, Choi D, Zhang J-G (2010) Synthesis and Characterization of Lithium Manganese Phosphate by a Precipitation Method. J. Electrochem. Soc. 157: A142-A147 f) Doeff MM, Chen J, Conry TE, Wang R, Wilcox J, Aumentado A (2010) Combustion Synthesis of Nanoparticulate $\mathrm{LiMg}_{x} \mathrm{Mn}_{1-\mathrm{x}} \mathrm{PO}_{4}(\mathrm{x}=0,0.1$, 0.2) Carbon Composites. J. Mater. Res. in press.

[119] Drezen T, Kwon N-H, Bowen P, Terrlinck I, Isono M, Exnar I (2007) Effect of Particle Size on $\mathrm{LiMnPO}_{4}$ Cathodes. J. Power Sources 174: 949-953. 
[120] a) Chen G, Wilcox JD, Richardson TJ (2008) Improving the Performance of Lithium Manganese Phosphate Through Divalent Cation Substitution.

Electrochem. and Sol. State Lett. 11: A190-A194 b) Shiratsuchi T, Okada S, Doi T, Yamaki J-I (2009) Cathodic Performance of $\mathrm{LiMn}_{1-x} \mathrm{M}_{\mathrm{x}} \mathrm{PO}_{4}(\mathrm{M}=\mathrm{Ti}, \mathrm{Mg}$, and $\mathrm{Zr}$ ) Annealed in an Inert Atmosphere. Electrochim. Acta 54:3145-3151 c) Bakenov Z, Taniguchi I (2010) LiMg $\mathrm{Mn}_{1-\mathrm{x}} \mathrm{PO}_{4} / \mathrm{C}$ Cathodes for Lithium Batteries Prepared by a Combination of Spray Pyrolysis with Wet Ballmilling. J. Electrochem. Soc. 157:A430-A436

[121] S. Martha K, Markovsky B, Grinblat J, Gofer Y, Haik O, Zinigrad E, Aurbach D, Drezen T, Wang D, Deghenghi G, Exnar I (2009) $\mathrm{LiMnPO}_{4}$ as an Advanced Cathode Material for Rechargeable Lithium Batteries. J. Electrochem. Soc. 156: A541-A552

[122] a) Yonemura M, Yamada A, Takei Y, Sonoyama N, Kanno R (2004) Comparative Kinetic Study of Olivine $\mathrm{Li}_{x} \mathrm{MPO}_{4}(\mathrm{M}=\mathrm{Fe}, \mathrm{Mn})$. J. Electrochem. Soc. 151: A1352-A1356 b) Yamada A, Chung S-C (2001) Crystal Chemistry of the Olivine-Type $\mathrm{Li}\left(\mathrm{Mn}_{\mathrm{y}} \mathrm{Fe}_{1-\mathrm{y}}\right) \mathrm{PO}_{4}$ and $\left(\mathrm{Mn}_{\mathrm{y}} \mathrm{Fe}_{1-\mathrm{y}}\right) \mathrm{PO}_{4}$ as Possible $4 \mathrm{~V}$ Cathode Materials for Lithium Batteries. J. Electrochem. Soc. 148: A960-A967 [123] Chen G, Richardson TJ (2009) Solid Solution Phases in the Olivine-Type $\mathrm{LiMnPO}_{4} / \mathrm{MnPO}_{4}$ System. J. Electrochem. Soc. 156: A756-A762

[124] a) Kim S-W, Kim J, Gwon H, Kang K (2009) Phase Stability Study of Li - $_{-}$ ${ }_{x} \mathrm{MnPO}_{4}(0 \leq x \leq 1)$ Cathode for Li Rechargeable Battery. J. Electrochem. Soc. 156:A635-A638 b) Chen G, Richardson TJ (2010) Thermal Instability of OlivineType $\mathrm{LiMnPO}_{4}$ Cathodes. J. Power Sources 195: 1221-1224

[125] a) Okada S, Sawa S, Egashira M, Yamaki J-I, Tabuchi M, Kageyama H, Konishi T, Yoshino A (2001) Cathode Properties of Phospho-Olivine $\mathrm{LiMPO}_{4}$ for 
Lithium Secondary Batteries. J. Power Sources 97-98: 430-432 b) Wolfenstine J, Allen J (2004) $\mathrm{LiNiPO}_{4}-\mathrm{LiCoPO}_{4}$ Solid Solutions as Cathodes. J. Power Sources 136: 150-153

[126] a) Deniard P, Dulac AM, Rocquefelte X, Grigorova V, Lebacq O, Pasturel A, Jobic S (2004) High Potential Positive Materials for Lithium-lon Batteries: Transition Metal Phosphates. J. Phys. Chem. Sol. 65: 229-233 [127] Chang X-Y, Wang Z-X, Li X-H, Zhang L, Guo H-J, Peng W-J (2005) Synthesis and Performance of $\mathrm{LiMn}_{0.7} \mathrm{Fe}_{0.3} \mathrm{PO}_{4}$ Cathode Material for Lithium Ion Batteries. Mater. Res. Bull. 40: 1513-1520

[128] Yamada A, Kudo Y, Liu K-Y (2001) Phase Diagram of $\mathrm{Li}_{x}\left(\mathrm{Mn}_{\mathrm{y}} \mathrm{Fe}_{1-\mathrm{y}}\right) \mathrm{PO}_{4}$ $(0 \leq x, y \leq 1)$. J. Electrochem. Soc. 148: A1153-A1158

[129] Bramnik NN, Bramnik KG, Nikolowski K, Hinterstein M, Baehtz C, Ehrenbert H (2005) Synchrotron Diffraction Study of Lithium Extraction from $\mathrm{LiMn}_{0.6} \mathrm{Fe}_{0.4} \mathrm{PO}_{4}$. Electrochem. and Sol. State Lett. 8: A379-A381 [130] a) Park Y-U, Kim J, Gwon H, Seo D-H, Kim S-W, Kang K (2010) Synthesis of Multicomponent Olivine by a Novel Mixed Transition Metal Oxalate Coprecipitation Method and Electrochemical Characterization. Chem. Mater. 22: 2573-2581 b) Gwon H, Seo, D-H, Kim S-W, Kim J, Kang K (2009) Combined First-Principle Calcuations and Experimental Study on Multi-Component Olivine Cathode for Lithium Rechargeable Batteries. Adv. Funct. Mater. 19:1-8 c) Seo D-H, Gwon H, Kim S-W, Kim J, Kang K (2010) Multicomponent Olivine Cathode for Lithium Rechargeable Batteries: A First-Principles Study. Chem. Mater. $22: 518-523$

[131] Goodenough JB, Hong Y-P, Kafalas JA (1976) Fast $\mathrm{Na}^{+}$-Ion Transport in Skeleton Structures. Mater. Res. Bull. 11: 203-220 
[132] a) Delmas C, Nadiri A (1988) The Nasicon-Type Titanium Phosphates $\mathrm{ATi}_{2}\left(\mathrm{PO}_{4}\right)_{3}(\mathrm{~A}=\mathrm{Li}, \mathrm{Na})$ as Electrode Materials. Sol. State Ionics 28-30: 419-423

b) Delmas C, Cherkaoui F, Nadiri A, Hagenmuller P (1987) A Nasicon-Type Phase as Intercalation Electrode: $\mathrm{NaTi}_{2}\left(\mathrm{PO}_{4}\right)_{3}$ Mat. Res. Bull. 22:631-639 c) Manthiram A, Goodenough JB (1989) Lithium Insertion into $\mathrm{Fe}_{2}\left(\mathrm{SO}_{4}\right)_{3}$ Frameworks. J. Power Sources 26:403-408

[133] a) Nanjundaswamy KS, Padhi AK, Goodenough JB, Okada S, Ohtsuka H, Arai H, Yamaki J (1996) Synthesis, Redox Potential Evaluation and Electrochemical Characteristics of NASICON-Related-3D Framework Compounds. Sol. State Ionics 92:1-10 b) Masquelier C, Padhi AK, Nanjundaswamy KS, Goodenough JB (1998) New Cathode Materials for Rechargeable Lithium Batteries: The 3-D Framework Structures $\mathrm{Li}_{3} \mathrm{Fe}_{2}\left(\mathrm{XO}_{4}\right)_{3}$ (X=P,As) J. Sol. State Chem. 135: 228-234

[134] a) Saïdi MY, Barker J, Huang H, Swoyer JL, Adamson G (2002) Electrochemical Properties of Lithium Vanadium Phosphate as a Cathode Material for Lithium-Ion Batteries. Electrochem. and Sol. State Lett. 5:A149A151 b) Morcrette M, Leriche J-B, Patoux S, Wurm C, Masquelier C (2003) In Situ X-Ray Diffraction during Lithium Extraction from Rhombohedral and Monoclinic $\mathrm{Li}_{3} \mathrm{~V}_{2}\left(\mathrm{PO}_{4}\right)_{3}$. Electrochem. and Sol. State Lett. 6:A80-A84 c) Yin, SC, Strobel, PS, Grondey $\mathrm{H}$, Nazar LF (2004) $\mathrm{Li}_{2.5} \mathrm{~V}_{2}\left(\mathrm{PO}_{4}\right)_{3}$ : A RoomTemperature Analogue to the Fast-Ion Conducting High-Temperature $\gamma$-Phase of $\mathrm{Li}_{3} \mathrm{~V}_{2}\left(\mathrm{PO}_{4}\right)_{3}$. Chem. Mater. 16:1456-1465

[135] a) Gover RKB, Burns P, Bryan A, Saidi MY, Swoyer JL, Barker J (2006) $\mathrm{LiVPO}_{4} \mathrm{~F}$ : A New Active Material for Safe Lithium-Ion Batteries. Sol. State lonics 177:2635-2638 b) Barker J, Gover RKB, Burns P, Bryan A, Saidi MY, Swoyer JL 
(2005) Structural and Electrochemical Properties of Lithium Vanadium Fluorophosphate, LiVPO ${ }_{4}$ F. J. Power Sources 146:516-520 c) Barker J, Gover RKB, Burns P, Bryan A (2005) A Symmetrical Lithium-Ion Cell Based on Lithium Vanadium Fluorophosphate, LiVPO ${ }_{4} \mathrm{~F}$. Electrochem. and Sol. State Lett. 8: A285-A287

[136] Gover RKB, Bryan A, Burns P, Barker J (2006) The Electrochemical Insertion Properties of Sodium Vanadium Fluorophosphate, $\mathrm{Na}_{3} \mathrm{~V}_{2}\left(\mathrm{PO}_{4}\right)_{2} \mathrm{~F}_{3}$. Sol. State Ionics 177: 1495-1500

[137] Ellis BL, Makahnouk WRM, Makimura Y, Toghill K, Nazar LF (2007) A Multifunctional 3.5V Iron-Based Phosphate Cathode for Rechargeable Batteries. Nat. Mater. 6: 749-753

[138] a) Ramesh TN, Lee KT, Ellis BL, Nazar LF (2010) Tavorite Lithium Iron Fluorophosphate Cathode Materials: Phase Transition and Electrochemistry of $\mathrm{LiFePO}_{4} \mathrm{~F}-\mathrm{Li}_{2} \mathrm{FePO}_{4} \mathrm{~F}$. Electrochem. and Sol. State Lett. 13:A43-A47 b) Recham N, Chotard J-N, Jumas J-C, Laffont L, Armand M, Tarascon J-M (2010) Ionothermal Synthesis of Li-Based Fluorophosphates Electrodes. Chem. Mater. 22: $1142-1148$

[139] a) Song Y, Zavalij PY, Chernova NA, Whittingham MS (2005) Synthesis, Crystal Structure, and Electrochemical and Magnetic Study of New Iron (III) Hydroxyl-Phosphates, Isostructural with Lipscombite. Chem. Mater. 17: 11391147 b) Marx N, Croguennec L, Carlier D, Bourgeois L, Kubiak P, Le Cras F, Delmas C (2010) Structural and Electrochemical Study of a New Crystalline Hydrated Iron(III) Phosphate $\mathrm{FePO}_{4} \cdot \mathrm{H}_{2} \mathrm{O}$ Obtained from $\mathrm{LiFePO}_{4}(\mathrm{OH})$ by lon Exchange. Chem. Mater. 22: 1854-1861 
[140] a) Gaubicher J, Le Mercier T, Chabre Y, Angenault J, Quarton M (1999) Li/ $\beta-V^{-} \mathrm{PO}_{4}$ : A New 4V System for Lithium Batteries. J. Electrochem. Soc. 146: 4375-4379 b) Kerr TA, Gaubicher J, Nazar LF (2000) Highly Reversible Li Insertion at $4 \mathrm{~V}$ in $\varepsilon-\mathrm{VOPO}_{4} / \alpha-\mathrm{LiVPO}_{4}$ Cathodes. Electrochem. and Sol. State Lett. 3: 460-462 c) Song Y, Zavalij PY, Whittingham MS (2005) $\varepsilon-V O_{P O}$ : Electrochemical Synthesis and Enhanced Cathode Behavior. J. Electrochem. Soc. 152:A721-A727

[141] Barker J, Gover RKB, Burns P, Bryan A (2005) LiVP $\mathrm{O}_{7}$ : A Viable LithiumIon Cathode Material?. Electrochem. and Sol. State Lett. 8:A446-A448 [142] a) Nytén A, Abouimrane A, Armand M, Gustafsson T, Thomas JO (2005) Electrochemical Performance of $\mathrm{Li}_{2} \mathrm{FeSiO}_{4}$ as a New Li-Battery Cathode Material. Electrochem. Commun. 7: 156-160 b) Dominko R, Bele M, Gaberscek M, Meden A, Remskar M, Jamnik J (2006) Structure and Electrochemical Performance of $\mathrm{Li}_{2} \mathrm{MnSiO}_{4}$ and $\mathrm{Li}_{2} \mathrm{FeSiO}_{4}$ as Potential Li-Battery Cathode Materials. Electrochem. Commun. 8: 217-222 c) Gong ZL, Li YX, Yang Y (2006) Synthesis and Characterization of $\mathrm{Li}_{2} \mathrm{Mn}_{x} \mathrm{Fe}_{1-\mathrm{x}} \mathrm{SiO}_{4}$ as a Cathode Material for Lithium Ion Batteries. Electrochem. and Sol. State Lett. 9: A542-A544 d) Belharouak I, Abouimrane A, Amine K (2009) Structural and Electrochemical Characterization of $\mathrm{Li}_{2} \mathrm{MnSiO}_{4}$ Cathode Material. J. Phys. Chem. C 113: 2073320737 e) Lyness C, Delobel B, Armstrong AR, Bruce PG (2007) The Lithium Intercalation Compound $\mathrm{Li}_{2} \mathrm{CoSiO}_{4}$ and its Behaviour as a Positive Electrode for Lithium Batteries. J. Chem. Soc Chem. Commun. 4890-4892 f) Armstrong AR, Lyness C, Ménétrier M, Bruce PG (2010) Structural Polymorphism in $\mathrm{Li}_{2} \mathrm{CoSiO}_{4}$ Intercalation Electrodes: A Combined Diffraction and NMR Study. Chem. Mater. 22:1892-1900 g) Dominko R (2010) Silicates and Titanates as High-Energy 
Cathode Materials for Li-Ion Batteries. Proc. of SPIE: Energy Harvesting and Storage: Materials, Devices and Applications OJ h) Zaghib K, Salah AA, Ravet N, Mauger A, Gendron F, Julien CM (2006) Structural, Magnetic and Electrochemical Properties of Lithium Iron Orthosilicate. J. Power Sources $160: 1381-1386$

[143] Nishimura S-I, Hayase S, Kanno R, Yashima M, Nakayama N, Yamada A (2008) Structure of $\mathrm{Li}_{2} \mathrm{FeSiO}_{4}$. J. Am Chem. Soc. 130: 13212-13213

[144] Arroyo-de Dompablo ME, Armand M, Tarascon JM, Amador U (2006) OnDemand Design of Polyoxianionic Cathode Materials Based of Electronegativity Correlations: An Exploration of the $\mathrm{Li}_{2} \mathrm{MSiO}_{4}$ System (M=Fe, Mn, Co, Ni). Electrochem. Commun. 8: 1292-1298

[145] a) Li H, Balaya P, Maier J (2004) Li-Storage via Heterogeneous Reaction in Selected Binary Metal Fluorides and Oxides. J. Electrochem. Soc. 151: A1878-A1885 b) Bervas M, Mansour AN, Yoon W-S, Al-Sharab JF, Badway F, Cosandey F, Klein LC, Amatucci GG (2006) Investigation of the Lithiation and Delithiation Conversion Mechanisms of Bismuth Fluoride Nanocomposites. J. Electrochem. Soc. 153: A799-A808

[146] Aurbach D (2000) Review of Selected Electrode-Solution Interactions Which Determine the Performance of Li and Li lon Batteries. J. Power Sources $89: 206-218$

[147] Jaiswal A, Horne CR, Chang O, Zhang W, Kong W, Wang E, Chern T, Doeff MM (2009) Nanoscale $\mathrm{LiFePO}_{4}$ and $\mathrm{Li}_{4} \mathrm{Ti}_{5} \mathrm{O}_{12}$ for High Rate Li-lon Batteries. J. Electrochem. Soc. 156:A1041-A1046 
[148] Ren Y, Armstrong AR, Jiao F, Bruce PG (2010) Influence of Size on the Rate of Mesoporous Electrodes for Lithium Batteries. J. Am. Chem. Soc. 132: 996-1004

[149] Sun Y-K, Myung S-T, Park B-C, Prakash J, Belharouak I, Amine K (2009) High Energy Cathode Material for Long-Life and Safe Lithium Batteries. Nat. Mater. 8:320-324

\section{Books and Reviews}

Ammundsen B, Paulsen J (2001) Novel Lithium-Ion Cathode Materials Based on Layered Manganese Oxides. Adv. Mater. 13: 943-956

Brodd RJ, Bullock KR, Leising RA, Middaugh RL, Miller JR, Takeuchi E (2004) Batteries, 1977 to 2002. J. Electrochem. Soc. 151:K1-K11

Bruce, PG (2008) Energy Storage Beyond the Horizon: Rechargeable Lithium Batteries. Solid State Ionics 179: 752-760

Ellis, BL, Lee, KT, Nazar, LF (2010) Positive Electrode Materials for Li-ion and Li Batteries. Chem. Mater. 22: 691-714

Fergus, JW (2010) Recent Developments in Cathode Materials for Lithium Ion Batteries. J. Power Sources 195:939-954

Goodenough, JB, Kim, Y (2010) Challenges for Rechargeable Li Batteries. Chem. Mater. 22: 587-603 Huggins RA (2009) Advanced Batteries, Materials Sciences Aspects. Springer Science + Business Media, LLC, New York Nazri GA, Pistoia O (eds) (2003) Lithium Batteries: Science and Technology. Kluwer Academic Publishers, Norwell Ohzuku T, Brodd, RJ (2007) An Overview of Positive-Electrode Materials for Advanced Lithium-Ion Batteries. J. Power Sources 174:449-456 
Palacin, MR (2009) Recent Advances in Rechargeable Battery Materials: A Chemist's Perspective. Chem. Soc. Rev. 38: 2565-2575

Tarascon J-M (2010) Key Challenges in Future Li-Battery Research. Phil Trans. Royal Soc. London A 368:3227-3241

Yamada A, Hosoya M, Chung S-C, Kudo Y, Hinokuma K, Liu K-Y, Nishi Y (2003) Olivine-Type Cathodes Achievements and Problems. J. Power Sources $119-121: 232-238$ 